\title{
The Mismeasure of Mammon: Uses and Abuses of Executive Pay Data
}

\author{
Matt Hopkins and William Lazonick*
}

Working Paper No. 49

Report to the Institute for New Economic Thinking on the statistical measurement and policy implications of the compensation of the highestpaid U.S. corporate executives

August 29, 2016

* William Lazonick is professor of economics, University of Massachusetts Lowell; visiting professor, University of Ljubljana; professeur associé, Institut Mines-Télécom; professorial research associate, SOAS, University of London; and president, The Academic- Industry Research Network, 12 Newport Road, Cambridge, MA 02140. (Corresponding Author: william.lazonick@gmail.com).

Matt Hopkins is a senior researcher at the Academic-Industry Research Network. 


\begin{abstract}
On April 7, 2016, the Wall Street Journal ran an article headlined "CEO pay shrank most since financial crisis," while on May 27, 2016, a similar New York Times story declared "Top CEO pay fell - yes, fell - in 2015." Unfortunately, both the Journal and the Times mismeasured the actual take-home pay of each and every one of these CEOs in 2014 and 2015. The reason for this mismeasure is that both articles relied on "fair value" estimates of the stock-based pay of these CEOs as reported in the Summary Compensation Table of the definitive proxy statement (Form DEF 14A) that each publicly listed company files annually with the U.S. Securities and Exchange Commission (SEC). Yet the very same proxy statements also report the actual realized gains of these CEOs in the Option Exercises and Stock Vested Table. It is the realized gains on stock-based pay, not fair-value estimates, that enter into the total compensation that a CEO actually takes home and reports as income in his or her income-tax return.

Moreover, including actual realized gains instead of estimated fair value of stockbased pay in the measure of total executive compensation can make a big difference. In 2014 average total compensation of the 500 highest-paid executives named on corporate proxy statements based on actual realized gains was $\$ 34.3$ million, with 81 percent coming from stock-based pay. But average total compensation of the 500 highest paid based on estimated fair value was $\$ 19.3$ million, with 62 percent attributable to stockbased pay. The excess of total actual realized-gains compensation over total estimated fair-value compensation was greatest in those years when the stock market was booming.

Why would the Wall Street Journal and the New York Times report estimates of executive pay when they could be reporting the CEOs' actual pay? In this paper, we answer this question by explaining the origins of the "fair value" estimates of stock-based pay and how the obsession with these estimates by the SEC, relying on the business-run Financial Accounting Standards Board (FASB), has relegated to statistical obscurity executives' readily available, accurate, and actual realized gains from stock-based pay. We use Standard \& Poor's ExecuComp database to document that a) stock-based pay, in the forms of realized gains from stock options and stock awards, dominates both the size of and the changes over time in the total compensation of the highest-paid senior executives; and b) the fair-value estimates of stock-based pay tend to understate, often substantially, the realized gains from stock-based pay that these executives actually receive.

An irony is that even critics of excessive executive pay, most notably the AFL-CIO on its Executive Paywatch website, use the fair-value estimates when the actual CEO compensation numbers would reveal a much larger ratio of CEO pay to the earnings of the average worker. Indeed, as we discuss in the conclusion to this paper, as mandated by the Dodd-Frank Wall Street Reform and Consumer Protection Act of 2010, this mismeasure of executive pay has become institutionalized in U.S. government policy in the SEC's Pay Ratio Disclosure Rule, which beginning in 2017 requires every company to publish the ratio of CEO to median-worker pay. Under this rule, the SEC requires companies to use the fair-value measure of CEO pay. The Pay Ratio Disclosure Rule is supposed to provide the public with a company-level indicator of income inequality. Instead it will tend to underestimate inequality, substituting fictitious estimates for actual known amounts of income that CEOs put into their bank accounts and declare in their income-tax returns.
\end{abstract}


JEL Codes: D22, D31, G35, J33, K22, L21, M41, M52

Keywords: Executive compensation, stock-based pay, stock options, stock awards, estimated fair value, actual realized gains, ExecuComp, SEC, FASB

Acknowledgements: We thank Thomas Ferguson, Director of Research, Institute for New Economic Thinking, for commissioning this report. Funding for this report and related research has been provided by the Institute for New Economic Thinking project on Collective and Cumulative Careers; European Commission project on Innovation-fueled Sustainable Inclusive Growth through its University of Ljubljana partner; and Ford Foundation project on Financial Institutions for Innovation and Development. We acknowledge the intellectual contributions of Ken Jacobson of the Academic-Industry Research Network and Jang-Sup Shin of the National University of Singapore, our collaborators on related research. Mustafa Erdem Sakinç and Emre Gomeç, both of the Academic-Industry Research Network, have constructed and maintained the stockbuyback database upon which we draw in this report. 


\section{Measures of stock-based executive pay}

Employment, productivity and earnings in the U.S. economy depend heavily on resourceallocation decisions made by the CEOs and their senior-management teams at a relatively small number of very large companies. ${ }^{1}$ Central to corporate resource-allocation decisions are the modes of compensation that incentivize and reward the top executives of these companies. A sound analysis of the operation and performance of the U.S. economy requires an understanding of not only how much these executives are paid but also the ways in which the prevailing system of executive pay influences their decisions to allocate corporate resources.

A company's senior executives, with the advice and support of the board of directors, are responsible for the allocation of corporate resources to investments in productive capabilities. Senior executives also advise the board on the extent to which, given the need to invest in productive capabilities, the company can afford to make cash distributions to shareholders. Over the decades, compensation experts have designed modes of compensation characterized by an array of different components that ostensibly incentivize executives to behave in ways that improve corporate performance and reward them for achieving performance goals. ${ }^{2}$

In the United States since the 1980s the overriding goal of U.S. corporations has been to "maximize shareholder value" (MSV), with corporate performance measured by a company's "total shareholder return": percentage stock-price appreciation plus dividend yield. Also since the 1980s, the most important components of the total compensation of senior executives have been modes of stock-based pay in the forms of stock options and stock awards. This stock-based pay is structured to incentivize executives to make corporate allocation decisions that will boost the stock prices of the companies that employ them and to reward them for achieving this objective.

A small but growing number of analysts of the business corporation, ourselves included, contend that, with a corporate focus on MSV, U.S.-style stock-based pay subverts the incentives of senior executives to invest in productive capabilities and rewards them for value extraction rather than value creation. ${ }^{3}$ The issue is not new. High and rising CEO

1 William Lazonick, "Labor in the Twenty-First Century: The Top 0.1\% and the Disappearing Middle Class," in Christian E. Weller, ed., Inequality, Uncertainty, and Opportunity: The Varied and Growing Role of Finance in Labor Relations, Cornell University Press, 2015: 143-192. In 2012 (the most recent data available), 964 companies that had 10,000 or more employees in the United States, with an average workforce of 33,542 , were only 0.017 percent of all U.S. businesses. But these 964 companies had nine percent of all establishments, 28 percent of employees, 31 percent of payrolls, and 36 percent of receipts. For 1,909 companies with 5,000 or more employees, these shares were 11 percent of establishments, 34 percent of employees, 38 percent of payrolls, and 44 percent of receipts. United States Census Bureau, "Statistics of U.S. Businesses," Data on "U.S., NAICS sectors, larger employment sizes" at http://www.census.gov/econ/susb/.

2 See, for example, Bruce R. Ellig, The Complete Guide to Executive Compensation, $3^{\text {rd }}$ edition, McGraw-Hill 2014.

3 See William Lazonick and Mary 0’Sullivan, "Maximizing Shareholder Value: A New Ideology for Corporate Governance," Economy and Society, 29, 1, 2000: 13-35; Mary O'Sullivan, Contests for Corporate Control: Corporate Governance and Economic Performance in the United States and Germany, Oxford University Press, 2000; Margaret M. Blair, "Shareholder Value, Corporate Governance, and Corporate Performance," in Peter K. Cornelius and Bruce Kogut, eds., Corporate Governance and Capital Flows in a Global Economy," Oxford University Press, 2003: 53-82; Steve Denning, "The Dumbest Idea in the World: Maximizing Shareholder 
pay has been a major policy concern in the United States for at least a quarter century. Graef S. Crystal, a prominent compensation consultant, provided a seminal critique in his 1991 book In Search of Excess: The Overcompensation of the American Executive. The front dust cover reads: "In the last 20 years the pay of American workers has gone nowhere, while American CEOs have increased their own pay more than $400 \%$. This is how they've done it." Crystal explains how CEOs of major U.S. corporations make use of compliant boards of directors and for-hire compensation consultants to justify everincreasing pay packages for themselves and the senior executives closest to them.

CEO compensation is far more outsized now than it was 25 years ago when Crystal wrote In Search of Excess. Yet a major barrier to reining in executive pay is the fact that, as we document in this paper, most analysts of the phenomenon in academic institutions, think tanks, labor unions, advocacy organizations, government agencies, and the news media systemically mismeasure executive compensation. For example, on April 7, 2016, the Wall Street Journal ran an article headlined "CEO pay shrank most since financial crisis," while on May 27, 2016 a similar New York Times story declared "Top CEO pay fell - yes, fell - in 2015." The fact is, however, that each and every reported pay package of some 300 CEOs in the Wall Street Journal story and 200 CEOs in the New York Times story mismeasures the actual pay that these CEOs took home in 2014 and 2015.

Both these articles use what are known as "fair value" measures of CEO pay, based on estimates, using grant-date stock prices, of the value of the newly vested stock options and stock awards received by these CEOs in 2014 and 2015. The executive-pay figures reported in these articles do not measure these CEOs' actual realized gains from exercising stock options and the vesting of stock awards in these years. Yet these realized gains on stock-based pay, not the fair-value estimates, are what these CEOs took home as compensation and reported to the Internal Revenue Service (IRS) on their personal income-tax returns.

Why would the Wall Street Journal and the New York Times report estimates of executive pay when they could be reporting the CEOs' actual compensation? In this paper, we answer this question by explaining the origins of the "fair value" measures of stock-based pay and how the obsession with these estimates has relegated to statistical obscurity executives' readily available, accurate, and actual realized gains from stock-based pay. We use Standard \& Poor's (S\&P) ExecuComp database to document that a) stock-based pay,

Value," Forbes, November 28, 2011, at http://www.forbes.com/sites/stevedenning/2011/11/28/maximizingshareholder-value-the-dumbest-idea-in-the-world/2/\#511aed3d2621; Roger L. Martin, Fixing the Game: Bubbles, Crashes, and What Capitalism Can Learn from the NFL, Harvard Business Review Press, 2011; Lynn Stout, The Shareholder Value Myth: How Putting Shareholders First Harms Investors, Corporations, and the Public, Berrett-Koehler Publishers, 2012; Ralph Gomory and Richard Sylla, "The American Corporation," Daedalus, 142, 2, 2013: 102-118; William Lazonick, "Innovative Enterprise and Shareholder Value," Law and Financial Markets Review, 8, 1, 2014: 52-64; William Lazonick, "Taking Stock: How Executive Pay Results in an Inequitable and Unstable Economy," Franklin and Eleanor Roosevelt Institute White Paper, June 5, 2014, at http://www.rooseveltinstitute.org/taking-stock-executive-pay; Susan Holmberg and Mark Schmitt, "The Overpaid CE0," Democracy, 34, Fall 2014, at http://democracyjournal.org/magazine/34/the-overpaid-ceo/.

4 Graef S. Crystal, In Search of Excess: The Overcompensation of the American Executive, Norton, 1991.

5 Theo Francis and Joanne S. Lublin, “CEO pay sank most since financial crisis," Wall Street Journal, April 7, 2016; David Gelles, “Top CEO pay fell - yes, fell - in 2015,” New York Times, May 27, 2016. 
in the forms of realized gains from stock options and stock awards, dominates both the size of and the changes over time in the total compensation of the highest-paid senior executives; and b) the fair-value estimates of stock-based pay tend to understate, often substantially, the realized gains from stock-based pay that these executives actually receive.

One dramatic example of this difference between fair-value and realized-gains measures is the total compensation of John C. Martin, CEO of Gilead Sciences, a drug company that has been in the public spotlight since 2013 because of the extraordinarily high prices of its Sovaldi/Harvoni medicines for Hepatitis-C. ${ }^{6}$ Based on the sales of these drugs, Gilead's revenues soared from a two-year total of \$20.9 billion in 2012 and 2013 to $\$ 57.5$ billion in 2014 and 2015, while the company's profits escalated from $\$ 5.7$ billion to $\$ 30.2$ billion. Gilead's stock price tripled during 2014 and 2015, boosted not only by its monopoly pricing of Sovaldi/Harvoni, but also by $\$ 15.3$ billion in stock buybacks. ${ }^{7}$

With price gouging and stock buybacks providing manipulative boosts to Gilead's stock price, the already substantial stock-based pay of the company's senior executives soared. ${ }^{8}$ In an op-ed entitled "Gilead's greed that kills," economist Jeffrey Sachs accurately describes Gilead as a company "driven by unquenchable greed," and goes on to say that "Gilead CEO John C. Martin took home a reported \$19 million in [2014] compensation the spoils of untrammeled greed." But the figure of $\$ 19.0$ million, which is reported as Martin's total 2014 compensation in the Summary Compensation Table of Gilead's proxy statement, includes the estimated fair-value measures of Martin's stock-based pay, not his realized gains.

In 2014 Martin actually took home $\$ 192.8$ million, and in 2015, when his estimated fairvalue pay was $\$ 18.8$ million, his actual take-home pay was $\$ 232.0$ million. From 1996 through 2015, as Gilead's CEO, Martin's estimated fair-value compensation totaled \$209 million but his actual realized-gains compensation totaled $\$ 1,001$ million, of which 82 percent came from stock options and 13 percent from stock awards. Gilead's drug-pricing policies and its stock buybacks helped Martin extract this massive stock-based pay. If \$19 million in annual compensation can be called "the spoils of untrammeled greed," what should we call the $\$ 193$ million and $\$ 232$ million that the Gilead CEO was actually paid in 2014 and 2015 ?

6 See the Staffs of Senators Ron Wyden and Charles E. Grassley, "The Price of Sovaldi and Its Impact in the U.S. Health Care System," Committee on Finance, United States Senate, December 1, 2015, p. 117, at http://www.finance.senate.gov/ranking-members-news/wyden-grassley-sovaldi-investigation-finds-revenuedriven-pricing-strategy-behind-84-000-hepatitis-drug; Médecins Sans Frontières, "The Cost of Medicine: A Special Report," Alert, Fall, 2015, at https://www.doctorswithoutborders.org/sites/usa/files/fall_2015_alert.pdf; William Lazonick, Matt Hopkins, Ken Jacobson, Mustafa Erdem Sakinç, and Öner Tulum, "Life Sciences? How 'Maximizing Shareholder Value' Increases Drug Prices, Restricts Access, and Stifles Innovation," Submission to the United Nations Secretary General's High-Level Panel on Access to Medicines, The Academic-Industry Research Network, February 28, 2016, at https://highlevelpaneldevelopment.squarespace.com/inbox/2016/3/1/the-academic-industryresearch-networka; Victor Roy and Lawrence King, "Betting on Hepatitis C: How Financial Speculation in Drug Development Influences Access to Medicines," BMJ, 354, 2016: i3718, at http://www.bmj.com/content/354/bmj.i3718.

7 In the first half of 2016 , Gilead did $\$ 9.0$ billion in buybacks and distributed $\$ 1.2$ billion in dividends.

8 Lazonick et al., "Life Sciences?" 
Our findings on "the mismeasure of mammon" presented in this paper are based on a deep dive into the ExecuComp database, which draws its information from the proxy statements that each U.S. business corporation must make available to shareholders in advance of the annual general meeting and file with the U.S. Securities and Exchange Commission (SEC) as Form DEF 14A. We document that the use of so-called fair-value accounting systematically mismeasures executive pay, though rarely to the extreme extent shown by the case of Gilead. We explain how and why the fair-value estimates of stock-based pay have been approved and, indeed, promoted by both the SEC and the business-run Financial Accounting Standards Board (FASB), as these agencies have ignored the actual take-home, money-in-the-bank compensation of these executives that, along with the fairvalue estimates, are reported in Form DEF 14A.

An irony is that even critics of excessive executive pay, most notably the AFL-CIO on its Executive Paywatch website, which features an annual CEO pay to average-worker pay ratio, ${ }^{9}$ use the fair-value estimates of executive compensation when the actual CEO compensation numbers would reveal a much larger gap between CEO pay and that of the average worker. Indeed, as we discuss in the conclusion to this paper, as mandated by the Dodd-Frank Wall Street Reform and Consumer Protection Act of 2010, this mismeasure of executive pay has become institutionalized in U.S. government policy in the SEC's Pay Ratio Disclosure Rule, which beginning in 2017, requires every company to publish the ratio of CEO to median-worker pay. Under this rule, the SEC requires companies to use the fair-value measure of CEO pay. ${ }^{10}$

It is not just the unfairness of the extraordinarily high amounts of pay that senior executives take home that is at issue. As we and our colleagues at the Academic-Industry Research Network have shown in many studies of specific companies and industries, the value-extracting behavior of senior executives, incentivized and rewarded by stock-based pay, bears prime responsibility for the concentration of income among the richest households and the erosion of middle-class employment opportunities in the United States. ${ }^{11}$ Specifically, we have shown how the incentives that stock-based pay provide for senior executives to allocate massive amounts of corporate resources to repurchasing the company's own stock contribute to unstable employment, inequitable earnings, and stifled innovation. ${ }^{12}$ Realized gains on stock-based pay and manipulation of a company's stock

9 AFL-CIO, "Executive Paywatch, at http://www.aflcio.org/Corporate-Watch/Paywatch-2016.

10 "SEC Adopts Rule for Pay Ratio Disclosure: Rule Implements Dodd-Frank Mandate While Providing Companies with Flexibility to Calculate Pay Ratio," Securities and Exchange press release, August 5, 2015, at http://www.sec.gov/news/pressrelease/2015-160.html.

11 Lazonick, "Labor in the Twenty-First Century."

12 William Lazonick and Öner Tulum, "US Biopharmaceutical Finance and the Sustainability of the Biotech Business Model," Research Policy, 40, 9, 2011: 1170-1187; William Lazonick, Mariana Mazzucato and Öner Tulum, "Apple's Changing Business Model: What Should the World's Richest Company Do With All Those Profits?" Accounting Forum, 37, 4, 2013: 249-267; William Lazonick, "Profits Without Prosperity: Stock Buybacks Manipulate the Market and Leave Most Americans Worse Off," Harvard Business Review, September 2014, 46-55; William Lazonick, "Numbers show Apple shareholders have already gotten plenty," Harvard Business Review Blog, October 16, 2014, at https://hbr.org/2014/10/numbers-show-apple-shareholders-havealready-gotten-plenty; William Lazonick, "What Apple should do with its massive piles of money," Harvard Business Review Blog, October 20, 2014, at https://hbr.org/2014/10/what-apple-should-do-with-its-massivepiles-of-money; Matt Hopkins and William Lazonick, "Who Invests in the High-Tech Knowledge Base?" Institute for New Economic Thinking Working Group on the Political Economy of Distribution Working Paper No. 6, 
price with stock buybacks are integrally related in a three-decades long process of what can only be described as the looting of the U.S. industrial corporation. ${ }^{13}$

The next section of this paper provides an overview of the history of stock-based pay in the United States to clarify the changing characteristics, functions, and impacts of stock options and stock awards. We will see that between 1950 and 1976, in what can be called Old Economy corporations, ${ }^{14}$ the main purpose of executive stock options was to provide senior executives with a tax dodge, enabling them to pay capital-gains taxes on the realized gains from stock options in lieu of the very high ordinary marginal income-tax rates that prevailed at the time. The 1980 s, however, saw the rise of broad-based stockoption plans at startup New Economy companies. ${ }^{15}$ These young companies used stock options to entice professional, technical, and administrative personnel to give up secure "career-with-one-company" employment with established Old Economy companies for the prospect of a substantial stock-based payday if and when the startup listed on a stock exchange. As the most successful New Economy corporations, now gone public, grew to employ tens of thousands of people, broad-based stock-option plans remained in place. During the 1990s most Old Economy corporations shed the norm of a career with one

September 2014 (revised December 2014), at https://ineteconomics.org/ideas-papers/research-papers/whoinvests-in-the-high-tech-knowledge-base; William Lazonick, Philip Moss, Hal Salzman, and Öner Tulum "Skill Development and Sustainable Prosperity: Collective and Cumulative Careers versus Skill-Biased Technical Change," Institute for New Economic Thinking Working Group on the Political Economy of Distribution Working Paper No. 7, December 2014, at https://ineteconomics.org/ideas-papers/research-papers/skilldevelopment-and-sustainable-prosperity-cumulative-and-collective-careers-versus-skill-biased-technicalchange; William Lazonick and Matt Hopkins, "GMs' stock buyback is bad for America and the company," Harvard Business Review Blog, March 11, 2015, at https://hbr.org/2015/03/gms-stock-buyback-is-bad-foramerica-and-the-company; William Lazonick, Matt Hopkins and Ken Jacobson, "McDonald's has to do more than manipulate its stock price," Harvard Business Review Blog, May 14, 2015, at https://hbr.org/2015/05/mcdonalds-has-to-do-more-than-manipulate-its-stock-price; William Lazonick, "U.S. companies don't need tax breaks on foreign profits," Harvard Business Review Blog, December 21, 2015, at https://hbr.org/2015/12/u-s-corporations-dont-need-tax-breaks-on-foreign-profits; William Lazonick, Öner Tulum, and Matt Hopkins, "Tax dodging just one part of Pfizer's corrupt business model," Huffington Post, December 4, 2015, at http://www.huffingtonpost.com/william-lazonick/tax-dodging-just-onepart_b_8721900.html; William Lazonick, "The Financialized Corporation and American Income Inequality," Perspectives on Work, 19, 2015: 30-34, 83-87; William Lazonick, "How Stock Buybacks Make Americans Vulnerable to Globalization," Paper presented at the Workshop on Mega-Regionalism: New Challenges for Trade and Innovation, East-West Center, University of Hawaii, Honolulu, January 20-21, 2016, at http://papers.ssrn.com/sol3/papers.cfm?abstract_id=2745387; Ken Jacobson and William Lazonick, "We stopped Pfizer's tax dodge, now let's end the buybacks," Huffington Post, April 8, 2016, at http://www.huffingtonpost.com/william-lazonick/we-stopped-pfizers-tax-do_b_9644166.html; William Lazonick, Matt Hopkins, and Ken Jacobson, "What we learn about inequality from Carl Icahn's \$2 billion 'no brainer,"' Institute for New Economic Thinking Ideas \& Papers, June 6, 2016, at https://ineteconomics.org/ideas-papers/blog/what-we-learn-about-inequality-from-carl-icahns-2-billionapple-no-brainer; William Lazonick, Matt Hopkins, Ken Jacobson, Mustafa Erdem Sakinç, and Öner Tulum "U.S. Pharma's Business Model: Why It Is Broken, and How It Can Be Fixed," in David Tyfield, Rebecca Lave, Samuel Randalls, and Charles Thorpe, eds., The Routledge Handbook of the Political Economy of Science, Routledge, forthcoming.

13 William Lazonick, “Stock Buybacks: From Retain-and-Reinvest to Downsize-and-Distribute," Center for Effective Public Management, Brookings Institution, April 2015, at http://www.brookings.edu/research/papers/2015/04/17-stock-buybacks-lazonick; Lazonick, "Labor in the Twenty-First Century"; William Lazonick, "Innovative Enterprise or Sweatshop Economics? In Search of Foundations of Economic Analysis," Challenge, 59, 2, 2016: 65-114.

14 Lazonick, Sustainable Prosperity in the New Economy? Business Organization and High-Tech Employment in the United States, W. E. Upjohn Institute for Employment Research, 2009, ch. 3.

15 Ibid, ch. 2. 
company, using stock options to incentivize and reward a broadening base of professional, technical, and administrative personnel.

The rise of broad-based stock option plans led the asset managers of pension funds and mutual funds, which invested a growing proportion of the nation's savings in shares of publicly listed corporations, to raise concerns about the implications of broad-based stock options for dilution of the shareholdings of the stocks in the funds' portfolios. The asset managers were far less concerned with the realized gains on stock-based executive pay than with the prospective compensation costs of stock-option plans, in terms of dilution, given to a broad base of employees. To aid decision-making concerning the buying, holding, and selling of stocks, the asset managers looked to the FASB to provide an upfront estimate of the "fair value" of this mode of compensation, based on grant-date stock prices.

Following our brief history of the evolution of stock-based pay, the paper documents how the FASB, with the regulatory support of the SEC, promoted the reporting and recording of "fair-value" stock-based compensation expenses based on Black-Scholes-Merton (BSM) stock-option pricing models. The fabrication and promulgation of these fair-value estimates of stock-based executive pay have driven the realized-gains measures - by far the most important components of actual executive compensation - out of sight and even out of mind.

With this historical perspective on the evolution and estimation of stock-based pay as indispensable background, we then explain the construction of the components of executive pay contained in the ExecuComp database and the various measures of total executive compensation that can be derived from combinations of these components. In this in-depth description of the ExecuComp database, it is essential to recognize the very different definitions and purposes of the variables that measure actual realized gains and estimated fair-value of stock options and stock awards. The task of describing the ExecuComp database must also specify the changes in variable definitions for components and totals of executive compensation introduced in 2006. At that time, under FAS 123R, the FASB and the SEC required companies not only to report but also to record fair-value estimates of stock-based compensation in their 10-K and 10-Q financial statements filed with the SEC. ${ }^{16}$

With this understanding of the contents of ExecuComp, we then provide results of the statistical analysis of the 500 highest-paid corporate executives in the database from 1992 through 2014. Our analysis shows that since the early 2000s fair-value measures of stockbased pay both understate actual executive compensation and fail to reflect stock-price volatility. These fair-value estimates also ignore the incentive and ability of executives to influence their own actual realized gains through various types of manipulative practices. In carrying out this analysis, we invoke a conceptual framework that views innovation, speculation and manipulation as three distinct but interrelated drivers of stock prices, with stock-based pay providing a powerful incentive for senior management to manipulate their

16 See FASB Accounting Standards Update, “Compensation - Stock Compensation,” (Topic 718), No. 2014-12, June 2014, at https://asc.fasb.org/imageRoot/85/51831185.pdf. 
company's stock price by allocating corporate resources to massive repurchases of the company's own outstanding shares..$^{17}$

Finally, we turn to the policy implications of the mismeasure of executive compensation for two initiatives, Say on Pay and the Pay Ratio Disclosure Rule, to rein in executive pay as mandated by the Dodd-Frank Act and implemented by the SEC. These two policy initiatives represent the nation's prime regulatory responses to the role of executive pay in incentivizing the reckless and greedy behavior that exacerbated the financial crisis of 2008-2009. We then emphasize that the executive-pay issue is not just a matter of how much top executives get paid but also how the ways in which they get paid influence corporate resource allocation. Underpinning senior executives' enormous realized gains from stock-based pay is the flawed ideology that a business corporation should be run to maximize shareholder value. We explain why public policy to bring top-executive pay under control must confront this debilitating ideology and put an end to the looting of the U.S. industrial corporation, incentivized by the stock-based pay of the people at the top.

\section{Executive stock-based pay: From tax dodge to market manipulation}

Stock-based compensation can take the forms of stock options and stock awards. Although most of the public discussion of stock-based pay focuses on the compensation of senior executives, and especially CEOs, a company may grant stock options and stock awards to a broad base of employees, with various conditions for realizing gains on these forms of compensation. In this section, we provide a select history of stock-based pay in order to explain when and why stock options and stock awards became important components of employee - including senior executive - compensation. We will then be in a position to explain the evolution of two different measures of stock-based pay: actual realized gains and estimated fair-value.

First, some basic information on stock options and stock awards:

An employee stock option gives the recipient the right to acquire a specified number of shares in the company for which he or she works by exercising the option to buy those shares at the stock-market price that prevailed on the date that the option was granted. Once an option vests, the employee can exercise the option, in whole or in part, at any time until the termination date specified in the option grant. The employee will only choose to exercise the grant if the market price is higher than the exercise price. The spread between the exercise price of the shares and their market price on the date that the option is exercised (in whole or in part) constitutes realized gains.

It is a common practice for the shares included in an option grant to vest, and hence become available for exercise, in 25 percent blocks one to four years from the grant date. A stock-option grant usually expires after ten years so that, if the recipient remains with the company, he or she has from six to nine years during which to choose, on any particular business day, to exercise the option to purchase some or all of its vested shares. Almost all employee stock options are nonqualified, which means that the realized gains

17 Lazonick, "Profits Without Prosperity"; Lazonick, "Stock Buybacks." 
are taxed at the ordinary income-tax rate at the time that the option is exercised and represent part of the employee's compensation. Far less common is the "incentive" (or qualified) stock option that (as explained below) must be held for at least one year after the exercise date to qualify for capital-gains tax treatment, with taxes due in the year in which the gains are realized by selling the shares.

A stock award gives the recipient employee the right to the shares in the award on the date that the award vests. A minimum restriction for an award to vest is that the employee must remain with the company for a certain period of time from the grant date (three years is a common duration). The award might carry other restrictions such as the need for the company to achieve a certain earnings-per-share (EPS) target in order for the award to vest. The achievement of a performance target may increase the number of shares in the award when it vests. When all restrictions have been met, and the award vests, the employee's realized gains are the market price of the company's stock on the vesting date times the number of shares in the award. Even if the market price on the vesting date is below the market price on the grant date, stock awards provide realized gains to the employee. These gains are taxed at the ordinary income-tax rate. Since the early 2000s stock awards have become more widely utilized as a mode of executive compensation. Previously the vast majority of stock-based pay grants were stock options.

After the creation of a permanent income tax under the 16th Amendment in 1913, considerable U.S. legislation concerning the gains from exercising an executive stock option focused on the appropriate tax treatment. ${ }^{18}$ At issue was whether the exercising of a stock option provided the executive with additional employee compensation or an ownership stake in the company. If it was simply compensation, then the taxable event occurred at the exercise date, with the spread between the exercise price and market price representing compensation and taxed at the ordinary income-tax rate. If, however, the acquired shares made the executive an owner, then the taxable event would occur when the executive decided to sell the shares, and if held for a sufficiently long time, the realized gains could be taxed at the capital-gains rate.

During the 1920s and 1930s, the IRS generally held that the taxable income generated by stock options was compensation, not capital gains, and hence should be taxed at the ordinary rate in the year in which the option was exercised. ${ }^{19}$ The company could then, as remains the case, include the employee's stock-based income as a compensation expense in its federal tax return. In effect, the IRS recognized that, as documented by Adolf Berle and Gardiner Means in their book The Modern Corporation and Private Property, in the large publicly-traded business corporation that had come to dominate the U.S. industrial economy, managerial control over the allocation of corporate resources had become separated from the ownership of corporate shares. ${ }^{20}$ Even the CEO was an employee to

\footnotetext{
18 Ellig, The Complete Guide, p. 451; Michael Long, "The Incentives Behind the Adoption of Executive Stock Option Plans in U.S. Corporations," Journal of the Financial Management Association, 21, 3, 1992: 12-21; Roy Wentz, "Current Developments in the Taxation of Compensation for Services Rendered," University of Miami Law Review, 175, 1957: 175-192; Kevin Murphy, "Executive Compensation: Where We Are, and How We Got There," Handbook of Economics of Finance, 2, A, 2013: 211-356.

19 Long, "The Incentives," p.16.

20 Adolf A. Berle and Gardiner C. Means, The Modern Corporation and Private Property, Macmillan, 1932.
} 
whom the corporation paid compensation in whatever forms that compensation might take. Indeed, the fundamental role of a listing on the New York Stock Exchange (NYSE) was to enable owner-entrepreneurs to exit from the successful companies that they had founded, leaving in place salaried professionals who had the abilities to manage the further growth of the firm. ${ }^{21}$

In 1937, however, Palmer v. Commissioner countered the IRS perspective on the managerial corporation by arguing that the stock-option grant gave the executive a "proprietary interest" in the company. The executive would pay taxes in the year in which he sold the acquired shares, and would be eligible for capital-gains tax rates while the employer was not permitted to book the executive's gains from the sale of the acquired shares as a tax-deductible expense.

Then in 1945, in Commissioner v. Smith, the Supreme Court reversed this position, ruling that all stock options were compensatory with the gains determined and taxable at the date the stock option was exercised. Redefined as employment income, the realized gains from the stock option were taxable at the ordinary income-tax rate and deductible to the issuing corporation as a business compensation expense. Given that in 1945 the marginal tax rate on income over $\$ 200,000$ was 94 percent while the capital-gains tax rate was 25 percent, this legal decision effectively discouraged stock options as a mode of executive compensation.

Corporate executives, however, lobbied for capital-gains treatment for stock options, contending that their managerial performance would be enhanced by having a proprietary interest in the corporations that employed them. The Revenue Act of 1950 acceded to this line of argument, defining a restricted stock option on which realized gains would be taxed as a capital gain. ${ }^{22}$ In 1950 the capital-gains tax rate was still 25 percent, while the marginal income-tax rate on income over $\$ 200,000$ was 84.4 percent. From 1951 through 1964 this top ordinary rate stood at 91 percent. $^{23}$

Under the 1950 Act, a restricted stock option was non-transferable, had an exercise price of at least 85 percent of the market price of the stock at the time it was granted, and could

21 Mary O’Sullivan, “The Expansion of the U.S. Stock Market, 1885-1930: Historical Facts and Theoretical Fashions," Enterprise \& Society, 8, 3, 2007: 489-542. On the managerial revolution that came to fruition by the 1920s, see Alfred D. Chandler, Jr., The Visible Hand: The Managerial Revolution in American Business, Harvard University Press, 1977. On Chandler's work, see William Lazonick, "Alfred Chandler's Managerial Revolution," in William Lazonick and David J. Teece, eds., Management Innovation: Essays in The Spirit of Alfred D. Chandler, Jr., Oxford University Press: 3-29. Contrary to conventional wisdom, raising capital from the stock market was not important for the growth of these companies. Shareholders in NYSE-listed companies were generally households who allocated some of their savings to buying and holding outstanding corporate shares of already successful industrial enterprises, with a view to securing flows of dividend income and the possibility, should they see fit to sell the shares, of reaping a capital gain. See William Lazonick, "Innovative Enterprise and Historical Transformation," Enterprise \& Society, 3, 1, 2002: 35-54.

22 Long, "The Incentives," p. 17; Arthur Dean, "Employee Stock Options." Harvard Law Review, 66, 8, 1953: 1403 1449. For a comprehensive documentation of changes in the tax laws relating to stock options, see Ellig, The Complete Guide, ch. 8 and Appendix C.

${ }^{23}$ See "Top Federal Income Tax Rates on Regular Income and Capital Gains since 1916," at http://www.ctj.org/pdf/regcg.pdf. 
expire up to ten years from the date of the grant. ${ }^{24}$ To be eligible for capital-gains treatment, the exercise price had to be at least 95 percent of the grant-date stock price and the shares acquired through the exercise of the option could not be sold for at least two years from the option grant date and for at least six months from the exercise date. ${ }^{25}$ The capital-gains tax was levied on the spread between the exercise price and the market price of the acquired stock at the time the stock was sold.$^{26}$ When gains on non-statutory (i.e., "unrestricted") options were taxed at the ordinary tax rate, the recipient had to pay the tax in the year that the option was exercised. An executive who chose to hold on to the acquired shares was then exposed to the risk that a subsequent decline in the stock price would reduce the gains on which high taxes had already been paid.

Under the Revenue Act of 1950, therefore, the restricted stock option was a tax dodge. At the same time, stock options, whether restricted or not, could incentivize executives to focus on the company's stock price and reward them for the company's stock-price performance. The realized gains from executive stock options could be the result of innovation-driven increases in stock prices. But stock options also gave senior executives a personal incentive to capitalize on speculative stock-price movements. ${ }^{27}$ These executives could also potentially gain from stock-price increases that resulted from the allocation of corporate resources to open-market stock repurchases, a mode of stock-price manipulation. But until the adoption of SEC Rule 10b-18 in November 1982, which would in effect legalize the use of stock repurchases (also known as buybacks) to manipulate a company's stock price, senior executives worked under the threat that the SEC might construe repurchases as stock-price manipulation. ${ }^{28}$ As a result, even with stock-based pay, before the adoption of Rule $10 \mathrm{~b}-18$ stock buybacks were minimal. ${ }^{29}$

With the income on the exercise of stock options taxed as capital gains, executive stock options became widespread among U.S. corporations in the 1950s. They averaged 36 percent of the total compensation of top executives of 50 large U.S. corporations over $1955-1963 .{ }^{30}$ In the late $1950 \mathrm{~s}$ and early $1960 \mathrm{~s}$, however, there was a public-opinion backlash against this enrichment of top executives. ${ }^{31}$ In a 1960 Harvard Business Review article entitled “Are Stock Options Getting Out of Hand?”, Erwin Griswold, Dean of

24 The following account of capital-gains taxation of executive stock options draws on William Lazonick, "The Explosion of Executive Pay and the Erosion of American Prosperity," Entreprises et Histoire, 57, 2009: 141-164.

25 Note that, until May 1991, under Section 16(b) of the Securities Exchange Act of 1934, most senior executives were classified as "insiders" who would, in any case, have to hold shares acquired from exercising a stock option for six months from the exercise date or forfeit the "short-swing" profits to the company. As we discuss below, in May 1991 the SEC ruled that this six-month holding period begins at the grant date, not the exercise date.

26 If, at the grant date, the exercise price was at least 95 percent of the market price, the entire gain at the date of sale of the shares acquired by exercising the option would be eligible for capital-gains tax treatment, providing the holding requirements were satisfied. If the exercise price was less than 95 percent of the grant-date market price (with a minimum of 85 percent), the exercise-price spread (in this case the difference between 85 percent and 95 percent) would be taxed at the ordinary rate at the date of sale of the shares.

27 J. A. Livingston, The American Stockholder, J. B. Lippincott, 1958, p. 16.

28 Ken Jacobson and William Lazonick, "SEC Rule 10b-18: A License to Loot," in progress, The Academic-Industry Research Network, June 2016.

${ }^{29}$ Lazonick, "Stock Buybacks."

30 Wilbur Lewellen, Executive Compensation in Large Industrial Corporations, Columbia University Press, 1968, p. 137.

${ }^{31}$ For a labor critique, see AFL-CIO, The Stock Option Scandal, Industrial Union Department AFL-CIO, 1959. 
Harvard Law School, criticized the tax rules on stock options for favoring a special class of people who did not make investments that justified capital gains. He argued that option grants focused the minds of executives more on speculative price movements of the company's stock than on the job of managing a large corporation. ${ }^{32}$ Griswold's intervention provoked a vigorous debate that included academic articles in Harvard Business Review and elsewhere. ${ }^{33}$ Non-academic participants in the debate included Henry Ford II, CEO of Ford Motor Company; Thomas Watson, Jr., CEO of IBM; Nelson Rockefeller, Governor of New York; and Albert Gore, U.S. Senator from Tennessee.

In 1961 Gore introduced a bill in Congress to rescind the tax privileges of executive stock options, arguing that the 1950 legislation created a "glaring loophole" in the tax law that had resulted in "flagrant abuses." "I4 In 1964 Congress revised the tax code pertaining to stock options. The "restricted" stock option of the 1950 Act became a "qualified" stock option; to qualify for capital-gains treatment, the option had to be exercised within five rather than ten years, and, upon exercise, the acquired stock had to be held for three years rather than six months. Qualified options also had to be exercised in the order in which they were granted. ${ }^{35}$ Each of these changes reduced the probability that the executive would realize gains from stock options. Nevertheless, in a 1965 New York Times article, "How to be rich without paying taxes," Gore continued his attack on executive stock options, noting that "Congress made some changes in the law last year, but its action fell far short of need." 36

Over the next decade, changes in relative tax rates served to erode the extent of the tax privilege of the stock-option gains of corporate executives. Congress lowered the ordinary tax rate on income over $\$ 200,000$ to 70 percent in 1965 , and progressively raised the capital-gains tax rate to a high of 39.9 percent in 1976, thus vastly reducing, but not eliminating, the tax advantage of qualified stock options. The Tax Reform Act of 1969 included the introduction of the Alternative Minimum Tax that meant that some executives would have to pay higher effective tax rates on their stock-option income even when it was eligible for capital-gains treatment.

The 1969 Act also created Section 83 to clarify rules concerning "transfers of property" for compensation, making tax treatment of restricted stock options consistent with other forms of deferred compensation. The "economic benefit" rule ensured that taxation on a stock option would occur in the year in which one could determine its "readily ascertainable fair value." 37 The readily ascertainable fair value of a qualified stock option

\footnotetext{
32 Erwin N. Griswold, “Are Stock Options Getting Out of Hand?" Harvard Business Review, 39, 4, 1961: 52-58.

33 Daniel M. Holland and Wilbur G. Lewellen, "Probing the Record of Stock Options," Harvard Business Review, 40, 2, 1962: 132-150; Erwin D. Campbell, "Stock Options Should Be Valued," Harvard Business Review 39, 4, 1961: 52-58; George E. Lent and John A. Menge, 1962, "The Importance of Restricted Stock Options in Executive Compensation," Management Record, June, 1962: 6-13; John C. Baker, "Stock Options at the Crossroads," Harvard Business Review, 41, 1, 1963: 22-29, 164-166.

34 "Gore bill would end stock option plans," Washington Post, April 15, 1961.

35 Bruce R. Ellig, "The Evolution of Executive Pay in the United States," Compensation \& Benefits Review, January/February, 2006: 55-61, at p. 57. See also V. Henry Rothschild 2nd, "The New Stock Option: Problems of the Smaller Company," Fordham Law Review, 33, 3, 1965: 393-414.

36 Albert Gore, "How to be rich without paying taxes," New York Times, April 11, 1965, p. 29.

${ }^{37}$ Bruce McNeil, “The Transfer of Property," Journal of Deferred Compensation, 17, 3, 2012: 18-61.
} 
would be on the date on which the stock acquired by exercising the option was sold, whereas that of a nonqualified stock option would be on the date that the option was exercised. The 1969 Act explicitly recognized the increasing importance of nonqualified stock options as a mode of corporate compensation, affirming the right of companies to count their employees' realized gains from stock options, taxed at the ordinary rate, as a compensation expense on corporate tax returns. ${ }^{38}$

Then, under the Tax Reform Act of 1976, Congress eliminated capital-gains treatment of all future employee stock-option grants. The argument prevailed that in the absence of a capital investment there was no justification for capital-gains taxes on the income from stock options, however long the shares might be held after exercise. Congress questioned whether qualified stock options were an effective managerial incentive, given the uncertainty of the stock market. Moreover, Congress noted that capital-gains treatment of a portion of executive compensation was not available to senior executives of non-public companies. ${ }^{39}$ In 1978 Graef Crystal - the compensation consultant who would later become a vocal critic of excessive executive pay - stated that qualified stock options, "once the most popular of all executive compensation devices, . . . have been given the last rites by Congress." 40

In the Economic Recovery Act of 1981, however, Congress restored the qualified stock option subject to capital-gains treatment, now calling it the "incentive" stock option. To qualify for capital-gains treatment, the stock option had to be awarded under a shareholder approved plan, have an exercise price of at least 100 percent of the market value of the stock at the date of the grant, expire no more than ten years from the date of the grant, and, when exercised, the acquired stock had to be held for at least two years after the grant date and one year after the exercise date. In bringing back this tax-favored stock option, however, Congress limited the value of the exercisable grant (that is, the number of shares in the grant times the exercise price) on which the executive could receive capital-gains treatment to no more than $\$ 100,000$ in a given year, with the possibility of rolling over half of the unused maximum over the next three years. ${ }^{41}$ In setting this limit, Congress ensured that these "incentive" stock options could not fuel an explosion in executive pay.

In the 1980s, however, the much lower taxes brought on by "Reaganomics" increased the popularity of nonqualified stock options as a mode of employee compensation. The 1981 Act lowered the highest-bracket tax rate to 50 percent on income (initially in 1982) over $\$ 85,600$, and in 1988 it was lowered much further to 28 percent on income over $\$ 30,050$. It now stands at 39.6 percent on incomes over $\$ 413,050$ single and $\$ 466,950$ married. ${ }^{42}$

\footnotetext{
38 Everett Jassy, "Incentive Stock Options: The Reincarnation of Statutory Stock Options Under the Economic Recovery Tax Act of 1981," Tax Law Review, 37, 357, 1982: 359-409. See also Arthur Lewis, "Hidden jokers in the tax deck," Fortune, 82, 1, 1970: 100-112; David Kraus, Jr. and David J. McLaughlin, "New look in executive stock plans," McKinsey Quarterly, Winter 1971: 44-54; George H. Foote, "Performance shares revitalize executive stock plans," McKinsey Quarterly, Winter 1974: 2-18.

39 Jassy, “Incentive Stock Options,” p. 362.

${ }^{40}$ Graef Crystal, Executive Compensation: Money, Motivation, and Imagination, American Management Association, 1978, p. 145; Crystal, In Search of Excess.

41 Ellig, "Evolution of Executive Pay," p. 58.

42 Meanwhile Congress lowered the capital gains tax rate to 20 percent in 1982, raised it to 28 percent in 1987, and lowered it again to 20 percent in 1997. The Job and Growth Tax Relief Reconciliation Act of 2003 (the
} 
The vast majority of stock-option grants that corporate executives receive are nonqualified, subject to the ordinary rate with taxes paid in the year that the option is exercised.

Until 1991, Section 16(b) of the 1934 Securities Exchange Act prevented most senior executives from reaping short-swing profits when they exercised their stock options by requiring that they wait at least six months before selling the shares acquired at the date of exercise. Any gains made by the sale of shares within this six-month period had to be handed over to the company. In 1991, however, by arguing that a stock option is a derivative, the SEC determined that henceforth the six-month waiting period would begin at the grant date, not the exercise date. Since the option grant date is always at least one year before the option vests and can be exercised, this reinterpretation of Section 16(b) means that top executives, as company insiders, can sell the shares acquired from stock options immediately upon exercise and keep for themselves what previously would have been short-swing gains.

What is more, under SEC Rule 10b-18, in effect since November 1982, a senior executive's privileged knowledge of the dates on which the company is actually doing stock repurchases can be material information for the timing of option exercises and hence the generation of realized gains. Rule $10 \mathrm{~b}-18$ provides the issuer with a "safe harbor" from charges of stock-price manipulation if, along with some other conditions, the number of shares that the company repurchases on any given day is less than 25 percent of the average daily trading volume of the shares over the previous four weeks. Under this safe harbor, companies with the most actively traded stocks can do hundreds of millions of dollars in buybacks per day (as examples within the safe harbor, Microsoft can do about $\$ 500$ million and Apple $\$ 1.4$ billion in buybacks per day), repeated, if the top executives so choose, day after trading day.

Even with SEC Rule 10b5-1, adopted in 2000 to control insider trading, top executives can time their option exercises and stock sales to increase their pay. ${ }^{43}$ In any case, the SEC does not collect data on the dates on which stock buybacks are done, and in the more than three decades that Rule 10b-18 has provided a safe harbor against stock-market manipulation in doing large-scale repurchases, the SEC has not investigated any executives for trading on the material non-public information of the dates on which buybacks are carried out. $^{44}$

"Bush tax cuts") further reduced the capital-gains tax rate to 15 percent. The current capital-gains tax rate is 20 percent for upper-income individuals and 15 percent for lower income.

43 Allan Horwich, "The Origin, Application, Validity, and Potential Misuse of Rule 10b5-1," The Business Lawyer, 61, May 2007: 913-954; Alan B. Jagolinzer, "SEC Rule 10b5-1 and Insider's Strategic Trade," Management Science, 55, 2, 2009: 231-259; Jesse Eisinger, "Repeated good fortune in timing of CEO's stock sale," New York Times Dealbook, February 19, 2014, at http://dealbook.nytimes.com/2014/02/19/repeated-good-fortune-intiming-of-c-e-o-s-stock-sale/.

44 See the letters by U.S. Sen. Tammy Baldwin to SEC Chair Mary Jo White of April 23, 2015, at (www.baldwin.senate.gov/imo/media/doc/Baldwin\%20Letter\%20to\%20SEC\%204\%2023\%2015.pdf) and November 16, 2015 (www.baldwin.senate.gov/imo/media/doc/111615\%20Letter\%20to\%20SEC.pdf) and Chair White's responses of July 13, 2015 (www.documentcloud.org/documents/2272283-sec-response-tobaldwin-07132015.html\#document/p1) and January 29, 2016 (copy in the possession of the authors). See also David Dayen, "SEC admits it's not monitoring stock buybacks to prevent market manipulation," The Intercept, August 12, 2015, at https://theintercept.com/2015/08/13/sec-admits-monitoring-stock-buybacks-prevent- 
On the advice of a compensation consultant hired by the CEO, the board of directors can make senior-executive compensation packages more lucrative by increasing the number of shares in a stock option or stock award. A compensation consultant tends to rank the CEO who has retained him or her above average in comparison with other CEOs, thus ratcheting up CEO pay over time. ${ }^{45}$ Moreover, CEOs sit on each others' boards, so that, through this ratchet effect, the acquiescence of these board members in approving generous senior-executive pay packages should ultimately augment their own compensation packages as CEOs. In recent years, stock awards have gained favor over stock options at many companies. Awards are never out of the money and it takes fewer shares using a stock award to reach a target level of senior-executive pay.

Given the prevailing norm for the number of shares contained in a stock option or stock award, CEOs and their boards have a number of methods available to them to increase the realized gains from the stock-based pay of senior executives: ${ }^{46}$

- They can reprice stock options for which the exercise price is lower than the market price (said to be "under water" or "out-of-the-money"), resetting the exercise price to the prevailing market price without disrupting the vesting period;

- They can reissue options at lower exercise prices, replacing the under-water options but as a result restarting the vesting period;

market-manipulation/.

45 Crystal, In Search of Excess; Geoffrey Colvin, Ann Harrington, and Paola Hjelt, "The great CEO pay heist," Fortune, June 25, 2001: 64-70; John Bizjak, Michael Lemmon and Lalitha Naveen, "Does the Use of Peer Groups Contribute to Higher Pay and Less Efficient Compensation?" Journal of Financial Economics, 90, 2, 2008: 152168; Michael Faulkender and Jun Yang, "Inside the Black Box: The Role and Composition of Compensation Peer Groups," Journal of Financial Economics, 96, 2, 2010: 257-270; Jay Lorsch and Rakesh Khurana, "The Pay Problem: Time for a new paradigm for executive compensation," Harvard Magazine, May-June 2010: 30-35; John Bizjak, Michael Lemmon, and Thanh Nguyen, "Are All CEOs Above Average? An Empirical Analysis of Compensation Peer Groups and Pay Design," Journal of Financial Economics, 100, 3, 2011: 538-555; Joe Mont, "Peer pressure: Is benchmarking to blame for runaway CEO pay?" Compliance Week, October 2, 2012: 60-62; Dana Hermanson, James Tompkins, Rajaram Veliyath and Zhongxia Ye, "The Compensation Committee Process," Contemporary Accounting Research, 29, 3, 2012: 666-709; Matthew Pittinsky and Thomas DiPrete, "Peer Group Ties and Executive Compensation Networks," Social Science Research, 42, 6, 2013: 1675-1692; Jenny Chu, Jonathan Faasse, and P. Raghavendra Rau, "Do Compensation Consultants Enable Higher CEO Pay? New Evidence from Recent Disclosure Rule Changes?" at SSRN, June 2016: http://papers.ssrn.com/sol3/papers.cfm?abstract_id=2500054.

46 The following practices are documented and discussed in Erik Lie, "On the Timing of CEO Stock Option Awards," Management Science, 51, 5, 2005: 802-812; Randall A. Heron and Erik Lie, "Does Backdating Explain the Stock Price Pattern Around Executive Stock Option Grants?" Journal of Financial Economics, 83, 2, 2007: 271-295; David Cicero, "The Manipulation of Executive Stock Option Exercise Strategies: Information Timing and Backdating," Journal of Finance, 64, 6, 2009: 2627-2663; William Parson and Diana Chase, "Swimming Through Underwater Stock Options: Strategies for Navigating Financial, Retention, and Motivation Obstacles," Journal of Employee Ownership Law and Finance, 21, 2009: 65-82; Ellen E. Schultz, The Retirement Heist: How Companies Plunder and Profit from the Nest Eggs of American Workers, Portfolio, 2011; Liu Zheng and Xianming Zhou, "Executive Stock Options and Manipulated Stock-Price Performance," International Review of Finance, 12, 3, 2012: 249-281; Lazonick, "Taking Stock"; Giuliano Bianchi, "Stock Options: From Backdating to Spring Loading," Quarterly Review of Economics and Finance, 59, 2016: 215-221; Sureyya Burcu Avci, Cindy A, Schipani, and H. Nejat Seyhun, "Ending Executive Manipulation of Incentive Compensation," University of Michigan Ross School of Business Working Paper 1305, February 2016, at http://papers.ssrn.com/sol3/papers.cfm?abstract_id=2740637. 
- They can issue options ahead of "good news" that may raise the stock price, so that, by "spring loading" (as the practice is called), the options that are granted have an advantageous exercise price;

- They can refrain from issuing options until after "bad news" that may depress the stock price, so that, by "bullet dodging," the options that are granted have an advantageous exercise price;

- They can issue option agreements that include reloading clauses so that new options are automatically awarded when the old ones are exercised;

- They can backdate the options granted to executives (including themselves) - a practice that is technically legal as long as the company discloses the backdating - so that, when stock prices are rising, they get the benefit of lower exercise prices, based on the lower stock prices that prevailed in earlier periods;

- They can increase the number of shares granted in the form of options or awards when the stock market is down so that these grants will generate all the more realized gains when the stock market recovers;

- They can authorize and execute large-scale open-market repurchases of the company's own shares, with immunity from charges of stock-price manipulation provided by the "safe harbor" under SEC Rule 10b-18 if, along with some other conditions, the number of shares repurchased on any given day is less than 25 percent of the average daily trading volume of the shares over the previous four weeks;

- They can influence stock prices using a number of accounting devices for manipulating reported earnings in 10-K and and 10-Q filings, including allocation of surpluses on employee pension obligations to corporate earnings and, as we shall discuss in detail, fair-value accounting for employee stock-based compensation.

As a result of increases in their stock-based pay since the 1980s, senior executives are well represented among the top one-tenth of one percent of households in the U.S. income distribution. Figure 1 displays data for 1916 to 2011 on the income shares of the top $0.1 \%$ of U.S. households, collected from tax returns by Thomas Piketty, Emmanuel Saez, and their colleagues. ${ }^{47}$ As can be seen, the largest component of executive pay over the past quarter century has been "salaries," supplemented by spikes in capital gains at the peaks of stock-market booms such as in 2000 and 2007. The "salaries" data, which also display spikes in stock-market booms, include substantial stock-based pay taxed at ordinary rates, which is not distinguished as stock-based in the data that Piketty and Saez have collected from personal income-tax returns. ${ }^{48}$

\footnotetext{
47 "The World Wealth and Income Database: http://topincomes.parisschoolofeconomics.eu/\#Database: United States, Top $0.1 \%$ income composition.

48 Almost all gains from exercising employee stock options and the vesting of employee stock awards are taxed at the ordinary income-tax rate, not at the capital-gains tax rate, with taxes withheld by the employer at the time that options are exercised or awards vest. Hence these stock-based gains are reported as part of "wages, tips, other compensation." IRS Form 1040 for individual income-tax returns has the line item (no. 7): "Wages, salaries, tips, etc. Attach Form(s) W-2," in which realized gains from stock-based pay are included but not shown separately from other forms of compensation. On Form W-2, the corresponding item is (no. 1) "Wages, tips, other compensation."
} 
Figure 1. Share of total U.S. incomes of the top $0.1 \%$ of households in the U.S. income distribution and its components, 1916-2011

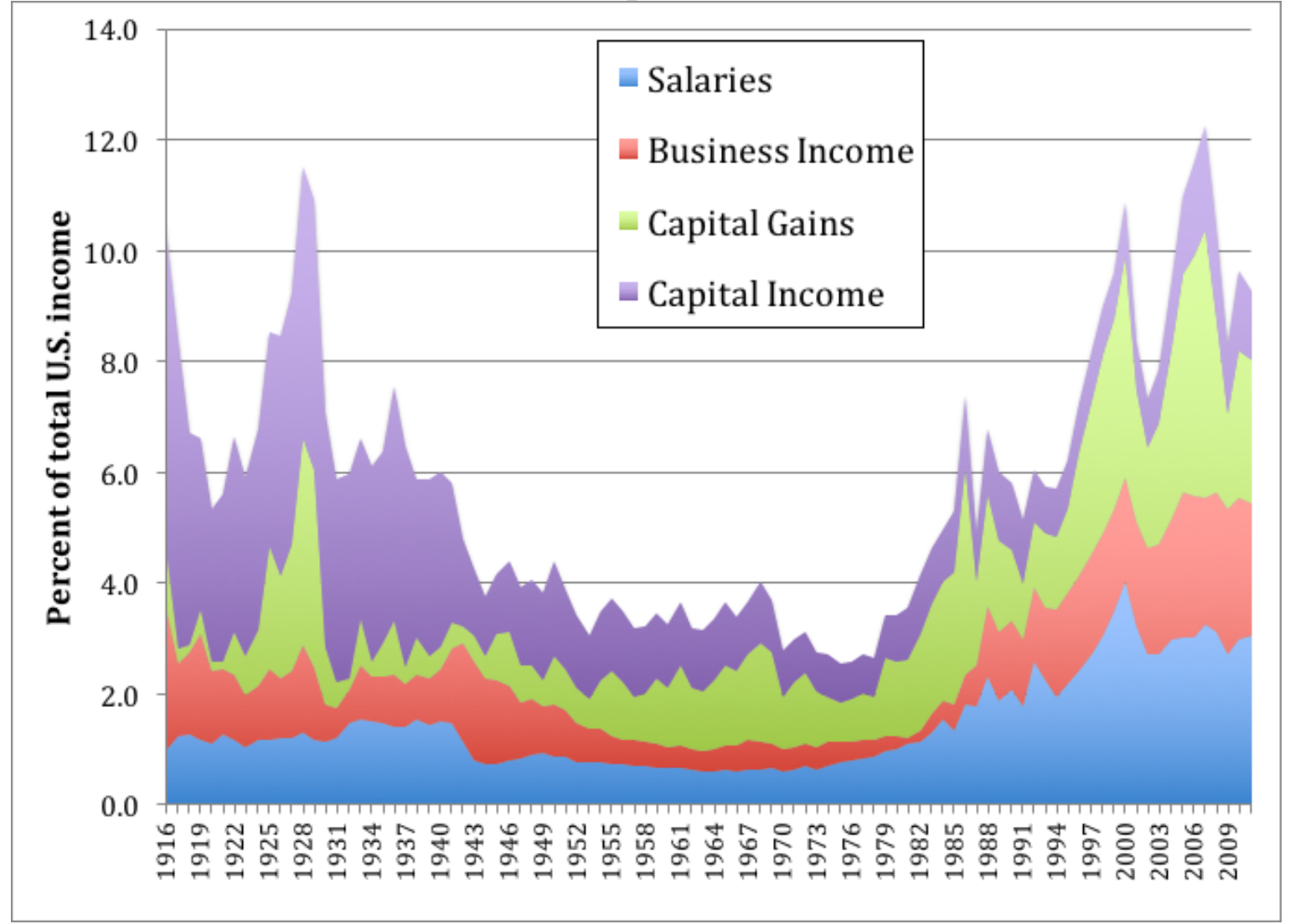

Source: http://topincomes.parisschoolofeconomics.eu/\#Database: United States, Top 0.1\% income composition.

Note: The category "salaries" includes compensation from the realized gains on exercising stock options and the vesting of stock awards.

Federal tax returns include information on a filer's occupation and, through an employer identification number (EIN) on Form W-2, the type of business sector that provides the taxpayer with his or her primary employment income. Jon Bakija, Adam Cole and Bradley Heim accessed federal tax return data for selected years from 1979 to 2005 to analyze the occupations of federal taxpayers at the top of the U.S. income distribution. They found that "executives, managers, supervisors, and financial professionals account for about 60 percent of the top $0.1 \%$ of income earners in recent years, and can account for 70 percent of the increase in the share of national income going to the top $0.1 \%$ of the income distribution between 1979 and 2005." ${ }^{49}$

For 2005, they found that, of taxpayers whose incomes (including capital gains) placed them in the top $0.1 \%$, executives, managers, and supervisors in non-finance businesses made up 41.3 percent of the total, while financial professionals (including management)

\footnotetext{
49 Jon Bakija, Adam Cole, and Bradley T. Heim, "Jobs and Income Growth of Top Earners and the Causes of Changing Income Inequality: Evidence from U.S. Tax Return Data," working paper, April, 2012, at https://web.williams.edu/Economics/wp/BakijaColeHeimJobsIncomeGrowthTopEarners.pdf. The quote is from the paper's abstract.
} 
were another 17.7 percent. Of the 41.3 percent who were non-finance executives, managers or supervisors, 19.8 percent were salaried and the rest were in closely held businesses. ${ }^{50}$ Besides the 6.2 percent of the top $0.1 \%$ who were "not working or deceased," the next largest occupational groups were lawyers with 5.8 percent, real estate with 5.1 percent, and medical with 4.1 percent.

We can use the ExecuComp database to get an idea of the representation of high-paid corporate executives among the top $0.1 \%$ of households in the income distribution. In 2012, for example, the threshold income including capital gains for inclusion in the top $0.1 \%$ of the income distribution was $\$ 1,906,047 .{ }^{51}$ From the ExecuComp proxy statement data on "named" top executives, in 2012, 4,330 executives (42 percent of the executives in the ExecuComp database that year) had total compensation greater than this threshold amount, with an average income of $\$ 8,533,000$. Of that amount, 68 percent were realized gains from stock-based compensation, with 34 percent derived from the exercise of stock options and the other 34 percent from the vesting of stock awards.

The number of corporate executives who, in 2012, were members of the top $0.1 \%$ club was, however, far higher than 4,330 for two reasons. First, total corporate compensation of the named executives does not include other non-compensation income (from securities, property, fees for sitting on the boards of other corporations, etc.) that would be included in their federal tax returns. If we assume that named executives whose corporate compensation was below the $\$ 1.91$ million threshold were able to augment that income by 25 percent (to pick a plausible number) from other sources, then the number of named executives in the top $0.1 \%$ in 2012 would have been 5,318 .

Second, included in the top $0.1 \%$ of the U.S. income distribution were a potentially large, but unknown, number of U.S. corporate executives whose pay was above the $\$ 1.91$ million threshold, but who were not named in proxy statements because they were not the $\mathrm{CEO}, \mathrm{CFO}$ or one of the three other named executives in their particular companies. For example, of the highest paid IBM executives in 2012 named in the company's proxy statement, the lowest paid had a total realized-gains compensation of $\$ 9,177,663$. There were presumably many other IBM executives whose total compensation was between this amount and the $\$ 1.91$ million threshold for inclusion in the top $0.1 \%$. These "unnamed" executives would have been among the top $0.1 \%$ in the income distribution.

The bottom line is that top executives of U.S. business corporations - industrial as well as financial - are very well represented among the top $0.1 \%$ of the U.S. income distribution, with much, and often most, of their compensation income coming from the realized gains from exercising stock options and the vesting of stock awards. When this mode of compensating top executives is combined with the fact that Wall Street has, since the 1980s, judged the performance of corporations by their quarterly stock prices, the importance of stock-based pay in executive compensation is clear. Stock-based pay gives top executives powerful personal incentives to boost, from quarter to quarter, the stock

\footnotetext{
50 Ibid., p. 38.

51 The World Wealth and Income Database, at http://topincomes.parisschoolofeconomics.eu/\#Database: United States, P99.9 income threshold.
} 
prices of the companies that employ them. In stock buybacks, these executives have found a potent, and SEC-approved, instrument for stock-market manipulation from which they can personally benefit, even if the stock-price boosts are only temporary.

While executives' realized gains on nonqualified stock-based pay are not directly measured in the IRS data on "salaries," these realized gains are included in the personal income-tax returns that these executives file with the IRS. For highly compensated senior executives who are named in corporate proxy statements, we know, by the inclusion of realized gains from stock-based pay reported in the proxy table on Option Exercises and Stock Vested, the exact amount of their total compensation, including the actual moneyin-the-bank realized gains from their stock-based pay. Why then do companies generate fair-value estimates of that stock-based pay? And why does the SEC accept these estimates of executive pay when the IRS taxes executives on their realized gains and indeed permits the companies that employ them to include these realized gains as taxdeductible compensation expenses in corporate tax filings?

The main determinant of both the IRS treatment and the SEC treatment of the stock-based pay of corporate executives is not senior executive compensation. Rather it is the growth over the past half-century or so of stock-option plans that partially compensate a broad base of corporate employees. The fact is that stock-based pay is not confined to senior executives or even to executives more generally. The realized gains on the nonqualified stock options of the broad base of employees are tax deductible as compensation in corporate tax returns. It was the explosive growth in the 1980s and 1990s of the use of broad-based stock-option plans to compensate non-executive professional, technical and administrative personnel, primarily in New Economy high-tech companies, ${ }^{52}$ that led the SEC to adopt "fair value" accounting methods for measuring stock-based pay. As we shall see in the next section of this paper, the rise of stock options as a mode of compensating a broad base of corporate employees is of critical importance to understanding the mismeasure of senior executive pay.

\section{Expensing stock-based pay: actual realized gains versus estimated "fair value"}

With the microelectronics revolution of the 1980s, New Economy companies in the information-and-communication technology (ICT) industries found themselves in competition for professional, technical, and administrative labor with Old Economy ICT companies such as Hewlett-Packard, IBM, Motorola, Texas Instruments and Xerox that in the 1980s still offered virtually all employees the realistic prospect of a career with one company. ${ }^{53}$ As young firms facing a highly uncertain future, New Economy companies could not attract labor away from Old Economy companies by the traditional promises of career employment with a defined-benefit pension after three or four decades of service. Instead, the New Economy startups used the inducement of stock options to attract and retain employees, a very high proportion of whom were college educated. When a young

\footnotetext{
52 Lazonick, Sustainable Prosperity, ch. 2. See also Justin Fox, "The next best thing to free money," Forbes, July 7, 1997; Justin Fox, The Myth of the Rational Market: A History of Risk, Reward, and Delusion on Wall Street, Harper Collins, 2009, ch. 15.

53 Lazonick, Sustainable Prosperity, chs. 2 and 3.
} 
company was able to do an initial public offering (IPO) on the highly speculative NASDAQ stock exchange within a few years of startup, many employees found that their stock options were worth hundreds of thousands or even millions of dollars. In the 1980s not all professional, technical, and administrative employees were willing to trade secure career employment for the prospect of a stock-based pay bonanza, but many were.

As the successful New Economy companies grew large, most, if not all, employees were partially compensated in stock options. For example, Cisco Systems had 250 employees in 1990, the year in which it did its IPO. After it had come to dominate the Internet communication equipment market a decade later, it had over 34,000 employees, virtually all of whom received stock options as part of their compensation. ${ }^{54}$

So that stock options would perform a retention function as well as an attraction function, the practice evolved in New Economy firms of making annual option grants, with 25 percent of an annual block of option grants vesting at the end of each of the first four years after the grant date. Once the options were vested, they could be exercised over a period of, typically, ten years from the grant date, as long as the employee remained with the company. Without creating the Old Economy expectation among employees of lifelong careers with the company, the perpetual pipeline of unvested options functioned as a tangible retention mechanism. Indeed, for most employees, the number of options that an individual could expect to receive was tied to his or her position in the firm's hierarchical and functional division of labor, so that the retention function of stock options was integrally related to the employee's career progress within the particular company. ${ }^{55}$

Nevertheless, it is important to emphasize that the original human-resource function of broad-based employee stock-option programs was to induce high-tech personnel to leave secure "career-with-one-company" employment at established Old Economy corporations for insecure employment in New Economy startups. When New Economy companies such as Intel (founded in 1968), Microsoft (1975), Oracle (1975), Sun Microsystems (1982), Dell Computer (1984), and Cisco Systems (1984) grew to be large, the Old Economy norm of a career with one company did not reappear. Rather, stock options were extended to tens of thousands of employees.

At some high-tech companies there was an interaction between the explosion of stockbased executive pay and the extension of stock options to a broader base of employees. Until 1997 Intel awarded stock options to only about half of its employees. As the Internet boom heated up in 1997 and the word spread among Intel's almost 50,000 employees that CEO Andrew Grove had realized gains of \$94.6 million from exercising stock options in 1996, the company expanded its stock-option program to include almost all of its employees. ${ }^{56}$

By the 1990s, major Old Economy companies, led by IBM, were shedding the "careerwith-one-company" employment norm as they transitioned to the New Economy model,

\footnotetext{
54 Ibid., pp. 39-79.

55 Ibid., pp. 39-79, 115-147.

56 Ibid., p. 54; David E, Kalish, “Intel chief nets \$94.6 million in stock options,” Associated Press, April 8, 1997.
} 
replacing employment security for scientists, engineers, and managers with a portion of their compensation as stock-based pay. ${ }^{57}$ At the beginning of the 1990s, IBM, like most Old Economy companies, reserved stock options for top executives. But in making the transition to the New Economy business model, IBM increasingly and substantially broadened the base of recipients of stock-based pay. In the early 1980s Hewlett-Packard (HP), an Old Economy company located in the heart of Silicon Valley, awarded stock options only to upper-level employees, but from the mid-1990s gradually extended stock options to a larger proportion of the labor force. In 1985 the proportion of HP employees holding options was only eight percent, but it increased to 18 percent in 1990, 25 percent in 1995, and 30 percent in 1998. At the height of the Internet boom, this proportion jumped sharply, first to 57 percent in 1999 and then to 98 percent in 2000. At the end of fiscal 2007, the proportion of HP employees holding options had declined to 58 percent, or 99,000 employees, but from 2000 all regular HP employees were eligible to receive options. $^{58}$

As these high-tech companies issued more and more options to a broad base of employees, stock options outstanding as a percent of total common stock outstanding - known as the "overhang" - mounted. ${ }^{59}$ The share of the overhang attributable to the compensation of top executives was relatively insignificant, despite the fact that the realized gains from stock options of top executives could be hundreds of times greater than those of the average company employee. ${ }^{60}$ The growth of the overhang was relevant to those whose shares of stock would be diluted when employees began exercising their stock options or receiving their stock awards, increasing the total number of shares of stock outstanding.

As the overhang increased, asset managers of pension funds and mutual funds became concerned about the consequent dilution of shareholding because their funds held large amounts of corporate stock. As shown in Table 1, by 1985 public and private institutional investors held almost one-third or all corporate equities, up from ten percent in 1965 and 20 percent in 1975 .

With the overhang growing at many companies, asset managers wanted to know the potential impact on EPS of stock-options when they were granted. Their concern was not the amount of realized gains that employees, including executives, might receive as compensation from their stock options. Rather, they were concerned with the impact that, because of dilution of the stocks in their funds' portfolios, large grants of stock options and stock awards would have on the company's stock price, cash dividends and stock repurchases.

\footnotetext{
57 Lazonick, Sustainable Prosperity, ch. 3.

58 Ibid., chs. 3 and 4.

59 Ibid., pp. 54-56.

60 Ibid., ch. 2.
} 
Table 1. Publicly listed corporate equities, United States, by type of shareholder, 1945-2015

\begin{tabular}{|c|c|c|c|c|c|c|c|c|}
\hline CORPORATE EQUITIES & 1945 & 1955 & 1965 & 1975 & 1985 & 1995 & 2005 & 2015 \\
\hline All sectors, billions of U.S..dollars & 152.9 & 298.7 & 734.9 & 839.4 & $2,270.4$ & $8,481.3$ & $20,600.5$ & $35,766.8$ \\
\hline \multicolumn{9}{|l|}{ Percent of total } \\
\hline All sectors & 100.0 & 100.0 & 100.0 & 100.0 & 100.0 & 100.0 & 100.0 & 100.0 \\
\hline Households and nonprofit organizations & 94.8 & 88.8 & 83.8 & 69.6 & 54.0 & 53.0 & 40.0 & 39.1 \\
\hline Federal government & 0.0 & 0.0 & 0.0 & 0.0 & 0.0 & 0.0 & 0.0 & 0.1 \\
\hline State \& local governments, excl. retirement fu & 0.0 & 0.0 & 0.0 & 0.0 & 0.0 & 0.3 & 0.6 & 0.5 \\
\hline Monetary authority & 0.0 & 0.0 & 0.0 & 0.0 & 0.0 & 0.0 & 0.0 & 0.0 \\
\hline U.S.-chartered depository institutions & 0.1 & 0.3 & 0.3 & 0.5 & 0.2 & 0.2 & 0.3 & 0.3 \\
\hline Foreign banking offices in the U.S. & 0.0 & 0.0 & 0.0 & 0.0 & 0.0 & 0.0 & 0.0 & 0.0 \\
\hline Property-casualty insurance companies & 1.2 & 1.8 & 1.6 & 1.7 & 2.5 & 1.6 & 1.0 & 0.9 \\
\hline Life insurance companies & 0.7 & 1.2 & 1.2 & 3.3 & 3.3 & 1.5 & 1.3 & 0.9 \\
\hline Private pension funds, including 403(b) plans & 0.0 & 2.0 & 5.5 & 12.9 & 21.8 & 13.9 & 11.1 & 6.3 \\
\hline Federal government retirement funds & 0.0 & 0.0 & 0.0 & 0.0 & 0.0 & 0.1 & 0.5 & 0.6 \\
\hline State \& local government DB retirement funds & 0.0 & 0.1 & 0.3 & 2.9 & 5.3 & 8.3 & 7.8 & 6.0 \\
\hline Mutual funds & 0.7 & 2.3 & 4.2 & 4.0 & 6.0 & 14.3 & 24.5 & 24.1 \\
\hline Closed-end funds & 0.5 & 0.9 & 0.8 & 0.7 & 0.2 & 0.5 & 0.5 & 0.3 \\
\hline Exchange-traded funds & 0.0 & 0.0 & 0.0 & 0.0 & 0.0 & 0.0 & 1.4 & 4.9 \\
\hline Security brokers and dealers & 0.4 & 0.3 & 0.2 & 0.4 & 0.6 & 0.4 & 0.8 & 0.5 \\
\hline Funding corporations & 0.0 & 0.0 & 0.0 & 0.0 & 0.0 & 0.0 & 0.0 & 0.0 \\
\hline Rest of the world, U.S. corporate equities & 1.8 & 2.2 & 2.0 & 4.0 & 6.0 & 5.7 & 10.3 & 15.6 \\
\hline \multicolumn{9}{|l|}{ INSITITUTIONAL INVESTORS } \\
\hline Private pension and mutual funds & 0.7 & 4.4 & 9.7 & 16.9 & 27.8 & 28.3 & 35.7 & 30.4 \\
\hline Private pension, mutual, and all govt. funds & 0.7 & 4.4 & 10.1 & 19.8 & 33.1 & 36.7 & 44.0 & 37.0 \\
\hline
\end{tabular}

Source: Board of Governors of the Federal Reserve System, "Financial Accounts of the United States," Federal Reserve Statistical Release, June 9, 2016 (Data download program, L.223 annual, corporate equities).

As applied to employee stock options, the FASB's "fair-value project" was a response to the growing demands of asset managers that corporate accounting provide them with an estimate of the cost of vested but unexercised options so they could factor this information into their decisions to buy, hold, and sell stock.$^{61}$ These demands for upfront accounting measures intensified with the bursting of the Internet stock-market bubble in 2001. The bankruptcy of Enron in December of 2001, number 18 on the Fortune 500 list, exposed the full extent of fraudulent accounting that had helped sustain the previous stock-market boom and reinforced the views of many regulators, accountants and asset managers of the need for the publication of better information on the estimated costs of stock-based compensation. ${ }^{62}$ Many held the failure to expense stock options in 10-K and $10-\mathrm{Q}$ financial statements to be partially responsible for artificially pumping up recorded corporate earnings, which in turn had driven stock prices to unsustainable peaks during the Internet boom. ${ }^{63}$

61 Robert K. Herdman, May 14, 2002, Testimony at SEC:

https://www.sec.gov/news/testimony/051402tsrkh.htm; Rebecca Shortridge, Amanda Schroeder and Erin Wagoner, "Fair Value Accounting," CPA Journal, 76,4, 2006: 37-39.

62 Nicolas Apostolou and Larry Crumbley, "Accounting for Stock Options: Update on the Continuing Conflict," CPA Journal, 75, 8, August 2005: 30-33.

63 Justin Fox, "The amazing stock option sleight of hand," Fortune, 143, 14, June 25, 2001; Zvi Bodie, Robert Kaplan and Robert Merton, "For the Last Time, Stock Options Are an Expense," Harvard Business Review, 81, 3, 2003: 62-71; James M. Bickley, "Employee Stock Options: Tax Treatment and Issues," Congressional Research Service, June 15, 2012, at https://www.fas.org/sgp/crs/misc/RL31458.pdf 
The result of the FASB fair-value project, with which the SEC joined forces in the late 1990s, was the implementation of FAS 123R for fiscal years beginning on or after July 1, 2005. FAS $123 \mathrm{R}$ requires a publicly listed corporation to use a BSM-type fair-value estimate to record the expense of employee stock options. ${ }^{64}$ Prior to FAS $123 \mathrm{R}$, as we detail below, the prevailing accounting principle had been that nonqualified stock options had a zero recorded accounting cost in a company's financial statements, even as they were being treated as a compensation expense in the company's tax returns.

When in 1984 and in the early 1990s the FASB had attempted to impose fair-value accounting so that the $10-\mathrm{K}$ and $10-\mathrm{Q}$ income-statement compensation expense for stock options would be greater than zero, it had encountered intense lobbying by New Economy firms concerned about the negative impact of lower financial-statement earnings on their stock prices. ${ }^{65}$ The compromise result was FAS 123, issued in 1995. Under FAS 123, a company could now report its net earnings and EPS in pro forma disclosures as if it had utilized a BSM-type stock-option pricing model to estimate the "fair value" of its stockoption compensation, publishing the input values used to derive the reported estimates in a footnote to its financial statements. But under FAS 123, the company was still free to record the expense of stock options as zero in its income statement.

Although from 1995 corporations could voluntarily expense stock options in their financial statements using a fair-value calculation, companies preferred reporting no stock-option expenses to shareholders even as they reported realized-gains expenses to the IRS. In 2004, the FASB noted that through 2002 virtually no companies had recorded a non-zero stock-option expense in their financial filings. Now FASB's hand was strengthened by the passage on June 30, 2002 of the Sarbanes-Oxley Act, which required more transparent corporate financial reporting. ${ }^{66}$ In March 2003 when the FASB announced its intention to re-visit the expensing rule that would become FAS 123R, 179 companies immediately announced that they would voluntarily expense their stock options in their financial statements in accord with FAS 123. By July 2004, just months ahead of the FASB's December 2004 release of FAS 123R, the number of companies voluntarily expensing had jumped to 753 . By June 2005 that number was over $850 .^{67}$

The prospect of FAS 123R and its implementation led many corporations with broadbased stock-option plans to change their stock-based compensation schemes to stock awards. Unlike stock options, the estimated expense of stock awards was already being recorded as a positive number in financial statements, with the fair-value measure being recognized on vesting at the grant-date stock price (in contrast to the realized gains from

\footnotetext{
64 SEC release, "Commission amends compliance dates for FASB statement no. 123R on employee stock options," April 24, 2005, at https://www.sec.gov/news/press/2005-57.htm.

65 Murphy, "Executive compensation,"; Fox, "The next best thing."

66 Kayleen St. John, "The Acceleration of Stock Options in Anticipation of FAS 123 (R)," University of Connecticut Storrs Honors Scholar Theses, Paper 61, 2008, pp. 4-5, at http://digitalcommons.uconn.edu/srhonors_theses/61.

${ }^{67}$ Ibid.; The Financial Accounting Standards Board, “Statement of Accounting Standards No. 123," December 2004, p.152, at http://www.fasb.org/jsp/FASB/Document_C/DocumentPage?cid=1218220124271\&acceptedDisclaimer=true; Mike McNamee, Amy Borrus and David Henry, "Options expensing is here to stay," BusinessWeek. June 20, 2005, p. 44.
} 
stock awards which are derived from the market price on the vesting date). It takes fewer shares given out as stock awards than as stock options to generate a target level of employee compensation, and hence stock awards cause less overhang and less dilution of shareholdings. Microsoft, which had been particularly generous in doling out stock options to a broad base of employees, was prominent in announcing its shift from options to awards in July 2003 . $^{68}$

Note, then, that the search for a fair-value measure of stock-option compensation had virtually nothing to do with the use of stock options for senior-executive compensation. Ultimately it is the prospect of realized gains from stock options that incentivizes senior executives. If a fair-value measure can provide these executives with useful information on what the realized-gains payoffs might be, then the estimates of the value of their stock options at the time they vest might give them incentives for staying with the company to reap those gains. But, in granting stock-based compensation to executives, the increase in future stock prices that will determine their eventual realized gains is precisely the unknown variable that stock-based pay is meant to incentivize. As we shall see in our analysis of the 500 highest-paid executive from 1992 through 2014, given the roles of innovation, speculation, and manipulation in driving a company's stock price, the fairvalue estimates of stock options and stock awards as components of executive compensation expenses are poor measures - and indeed mismeasures - of actual realized gains.

Meanwhile, focusing on realized gains, the IRS took a very different approach to the expensing of stock options than the FASB and the SEC. The IRS was concerned with the rules for taxing the actual realized gains from stock-based income of employees, including senior executives. Already in the 1960s the IRS was considering the compensation implications for corporate taxation of a growing volume of stock options that companies were awarding to employees. From 1964, when, as we have seen, the restricted stock option became a qualified stock option, executives had to wait three years to sell the acquired shares after the date they exercised stock options to avail themselves of the capital-gains tax rate. For individual employees, the realized gains from all other stock options that did not qualify for capital-gains treatment were taxed at the ordinary incometax rates. The question for the IRS was how a company that employed these individuals should expense the realized gains from stock-based pay in its federal corporate income-tax return.

During the period 1950 to 1976 , legislation in place construed executives as shareholders when they exercised restricted or qualified stock options and continued to hold the shares for the requisite period of time to secure capital-gains tax treatment. Accordingly, the IRS did not permit the stock-option income taxed at the capital-gains tax rate to be counted as a corporate compensation expense in the company's federal tax filings. By the same logic, the IRS did not view the recipients of nonqualified stock options as shareholders because, with their compensation income being ineligible for capital-gains taxation, they had no

68 Robert A. Guth and Joann S. Lublin, “Tarnished gold: Microsoft ushers out era of options,” Wall Street Journal, July 9, 2003; John Markoff and David Leonhardt, "Microsoft will award stock, not options, to employees," New York Times, July 9, 2003. 
inherent incentive to hold the shares acquired from stock options once they were exercised.

Given that stock-option recipients could choose to exercise their options on any particular business day over a period of years, it would presumably be the case that one would refrain from exercising the option now if one expected that the price of the company's stock would move higher in the future. Moreover, upon exercise of the nonqualified stock option, the recipient had to pay taxes on the gain in the year that it was realized, providing an additional reason why he or she might want to lock in the gain by selling the shares immediately. Even if he or she chose to hold on to some or all of the shares, that would be a discrete personal decision to act as a shareholder, unconnected with the compensation that the recipient realized at the point at which those shares were acquired.

The IRS, therefore, does not consider an employee, including a top executive, who exercises a nonqualified stock option to be, as a result, a shareholder. Rather, the recipients of nonqualified stock options are more accurately described as sharesellers. ${ }^{69}$ Indeed, the IRS has always viewed the realized gains from the exercise of nonqualified stock options as just another form of employee compensation income to be taxed at the ordinary tax rate in the year that the options are exercised.

The IRS principle for the timing of the taxing of the gains on stock-based income was and remains that income on stock-based compensation is taxed at its readily ascertainable fair value. According to this IRS principle, at the grant date, the fair value of an employee stock option or a restricted stock award is unascertainable, and hence, for income-tax purposes, no "fair value" measure of a recipient's taxable income from the options or awards can be determined. Fair value is readily ascertainable when an actual transfer of money occurs or the risk of forfeiture of the right to that transfer of money lapses, whichever comes first.

As we have seen, since the Economic Recovery Tax Act of 1981, a qualified stock option known as an "incentive" stock option permits the recipient to secure capital-gains treatment in the year that the acquired shares are sold by holding those shares for at least one year from the exercise date, but with a limit of $\$ 100,000$ exercisable options in a given year. With incentive stock options, readily ascertainable fair-value income occurs when the shareholder actually sells the shares. Within this $\$ 100,000$ limit, the IRS accepts that the realized gains from stock options are not a compensation expense of the corporation, but rather the grant to the executive of a capital stake in the company. Nevertheless, the $\$ 100,000$ limit on exercisable options was a compromise in the Tax Act of 1981 after Congress had abolished capital-gains treatment of stock options in 1976. In effect, since 1981, Congress is willing to view the executive as a " $\$ 100,000$ shareholder," but beyond that recognizes that, after all, the executive is really an employee of the corporation and stock options are really employee compensation. ${ }^{70}$

\footnotetext{
${ }^{69}$ It is a mistake, therefore, to view stock options as a form of worker ownership, as put forward for example in Douglas L. Kruse, Richard B. Freeman, and Joseph R. Blasi, eds., Shared Capitalism at Work: Employee

Ownership, Profit and Gain Sharing, and Broad-Based Stock Options, University of Chicago Press, 2010.

70 Deborah Rankin, “Personal finance: Applause for the 'incentive' stock option,” New York Times, August 16, 1981.
} 
Given the magnitudes of top executive compensation that have prevailed since the 1980s, the $\$ 100,000$ limitation of exercisable options eligible for capital-gains treatment means that the vast majority of stock options granted to executives are nonqualified. As just explained, for income-tax purposes the realized gains on these nonqualified options are treated as compensation by both the recipients and the company. The resultant corporate income-tax savings are then recorded in the company's 10-K filing as an "excess tax benefit from stock-based pay," including tax savings from expensing realized gains from stock awards as well as stock options. ${ }^{71}$ For example, reflecting the enormous realized gains of employees from exercising stock options in the Internet boom, the amounts of excess tax benefit from stock-based pay recorded for 1999, 2000, and 2001 were, for Cisco, $\$ 0.8$ billion, $\$ 2.5$ billion, and $\$ 1.4$ billion; for Microsoft, $\$ 3.1$ billion, $\$ 5.5$ billion, and $\$ 2.1$ billion; and for Intel, $\$ 0.5$ billion, $\$ 0.9$ billion, and $\$ 0.4$ billion. ${ }^{72}$ These amounts are the tax savings that these companies reaped by including the realized gains from stock options and stock awards as part of actual employee compensation expenses in their federal corporate income-tax returns.

Along with the cash that employees pay to the company when they exercise their stock options, the excess tax benefit from stock-based pay appears in the shareholders' equity statement of the 10-K filing as an increase in cash attributable to shareholders ("additional paid-in capital"), partially offset by a reduction in the value of treasury shares sold to employees when they exercised their options or when their stock awards vested. For the IRS, the rationale for linking the compensation expense to shareholders' equity is that the corporation could have reaped that cash benefit for itself if it had sold on the stock market the shares that it transferred to employees as stock-based compensation. ${ }^{73}$

Yet, at the same time as the corporation records in its shareholders' equity statement the tax-savings from treating realized gains on stock-based pay as a compensation expense, a very different measure of "fair value" is recorded as a stock-based pay expense in the 10$\mathrm{K}$ income statement (also known as the statement of operations). ${ }^{74}$ Rather than use the readily ascertainable fair value of this pay, as the IRS requires in corporate tax returns, the SEC permits, and indeed requires, a company to record the estimated - or, by IRS standards, unascertainable - "fair value" of stock options and stock awards in calculating the net income that it reports to the financial markets.

We have already recounted the conditions under which the FASB, in collaboration with the SEC, promulgated FAS 123R, which required the "fair value" expensing of stock options using a BSM-type model. Since fiscal 2006, this fair-value estimate of the compensation expense of employee stock options along with a fair-value estimate of the

\footnotetext{
71 A term such as "excess tax benefit from stock-based compensation" may also be used. See, for example, Microsoft 10-K, 2015, p. 50.

72 See, for example, John Graham, Mark Lang, and Douglas Shackelford, "Employee Stock Options, Corporate Taxes, and Debt Policy," Journal of Finance, 59, 4, 2004: 1585-1618.

73 Benjamin Templin, “Expensing Isn't the Only Option: Alternatives to the FASB's Stock Option Expensing Proposal," Journal of Corporation Law, 30, 2004: 357-405.

74 In March 2016, the SEC announced that, for fiscal years beginning after December 15, 2017, the presentation of the stock-option income-tax benefit on 10-Ks will shift from the shareholders' equity statement to the income statement - a change that we will critique in the conclusion of this paper.
} 
expense of employee stock awards have been used in corporate income statements in their $10-\mathrm{K}$ and 10-Q filings with the SEC. These stock-based pay measures are estimates of the fair value of all employees'vested but unexercised stock options and vested stock awards, using the grant-date stock price. In sharp contrast, the IRS's stock-based compensation measures are the realized gains from exercised stock options and vested stock awards that the employee actually receives using the stock prices on the dates the options are exercised and the awards vest. To repeat, for the IRS, the SEC's approved "fair value" measure is based on unascertainable value and hence is not eligible to be used as the corporation's stock-based compensation expense in filing its corporate income-tax return.

If a company can record its employees' realized gains on their stock-based compensation as an expense in its IRS income-tax return and show an excess tax benefit from stockbased pay in its 10-K filing with the SEC, why doesn't it record those same realized gains as an expense in its $10-\mathrm{K}$ income statement? Rather than follow IRS practice, the SEC has long relied on the business sector to set the "generally accepted accounting principles" (GAAP) that govern reporting in financial statements filed with it. Until 1973 the business-sector authority for setting U.S. accounting standards was the Accounting Principles Board (APB), a committee of the American Institute of Certified Public Accountants. In 1973, APB was replaced by the FASB, an independent business-sector body that makes rulings, after public comment, on GAAP.

In 1972, three years after Congress reaffirmed in the Tax Reform Act of 1969 that realized gains on nonqualified stock options constitute a compensation expense in corporate tax returns, APB issued APB 25 (Accounting for Stock Options Issued to Employees), ruling that, for accounting purposes, a stock-based compensation expense is the intrinsic value of the stock option or stock award on the grant date. Under ABP 25 a business corporation expenses both options and awards in its financial statements. But if, as was typically the case, a company issued stock options with an exercise price equal to the grant-date market price of the stock, APB 25 said that the intrinsic value of the option, and hence the option expense, was zero. The intrinsic value of a stock award was deemed to be the grant-date stock price times the number of shares in the award, and hence a positive number that reflects the fact that a stock award does not have an exercise price.

In effect, intrinsic value under APB 25 was the sum of money that one would be willing to pay for the option or award on the grant date under the false assumption that the option could be exercised or the award would vest on the grant date. If so, the shares acquired could then be sold at the grant-date stock price. All employee stock options and stock awards, however, take time to vest. All stock options require a minimum waiting period of at least one year to vest, and the most typical practice is for the shares included in an option to vest in 25 percent increments over one to four years from the grant date. Stock awards are also called "restricted" stock grants, with a typical restriction being that the employee must wait a stated number of years for the award to vest. Indeed, as a mode of compensation, at a minimum the purpose of stock-based pay is to incentivize the employee to stay with the company for a stated period of time. 
Under the authority of the FASB, APB 25 remained in effect until 1995 when it was superseded by FAS 123, which required, as we have seen, that companies report but not necessarily record the cost of stock-based compensation in their SEC filings. FAS 123 expressed a preference for a company to report "fair value" estimates of stock-option expenses, but permitted the company to continue with the intrinsic-value (APB 25) approach. The essence of the FASB approach has been to look for upfront estimates of the potential liability for future compensation expenses posed by employee stock options and stock awards.

But unless one can predict future stock prices and the date on which a recipient will choose to exercise stock options, the "fair value" estimates of stock options advocated by the FASB for reporting to shareholders will not, except by chance, be equivalent to the IRS "readily ascertainable fair value" cash transfers that constitute the realized gains from stock-based compensation for personal and corporate income-tax purposes. In any given year, moreover, the fair-value estimate for stock options may be for shares that will only be exercised in later years. In the case of stock awards, the only way in which the fairvalue estimate will be the same as actual realized gains is if the grant-date price of the stock is the same as the vesting-date price.

As we have explained, during the 1980s and 1990s, with the rise of New Economy firms with broad-based stock-option plans, asset managers at pension funds and mutual funds pressed the FASB to require companies to report and record upfront estimates of the compensation expense of the vast numbers of shares that a company was committed to supply to employees as part of their pay packages. ${ }^{75}$ Asset managers found the zero intrinsic value of stock options under APB 25 unhelpful; they wanted the FASB to institute a valuation method that would tell them, in advance, the estimated expense of stock-based employee compensation.

Reflecting this concern, the FASB replaced APB 25 with FAS 123, which attached a positive number to options granted "at the money." The FASB wanted a measure that would estimate the expected value of an employee stock option, with a probabilistic calculus of the prospective future returns. ${ }^{76}$ In 1973, a year after the promulgation of APB 25, Fischer Black and Myron Scholes as well as Robert Merton had published their nowfamous papers on pricing options traded on financial markets. The financial (as opposed to

\footnotetext{
75 James DeLong, The Stock Options Controversy and the New Economy," Competitive Enterprise Institute, June 2002: 1-25 at https://cei.org/studies-issue-analysis/stock-options-controversy-and-new-economy; Amy Borrus, Paula Dwyer, Dean Foust and Louis Lavetie, "To expense or not to expense," BusinessWeek, July 29, 2002: 44-47; Robert Hof and Jim Kersetter, "Earth to Silicon Valley: You've lost this battle," BusinessWeek, July 12, 2004: 75-76; Mike McNamee, Amy Borrus and Henry David, "Options expensing is here to stay," BusinessWeek, June 20, 2005:44; James M. Bickley, "Employee Stock Options: Tax Treatment and Issues," Congressional Research Service, June 15, 2012, at https://www.fas.org/sgp/crs/misc/RL31458.pdf; Murphy, "Executive Compensation."

76 FASB Statement of Financial Accounting Standards number 123. "Accounting for Stock-Based Compensation," Financial Accounting Foundation, Norwalk, Connecticut, October 1995 at: http://www.fasb.org/jsp/FASB/Document_C/DocumentPage?cid=1218220124241\&acceptedDisclaimer=true; FASB, "Statement of Financial Accounting Standards number 123 (Revised December 2004)," Financial Accounting Foundation, Norwalk, Connecticut, (2010) at

http://www.fasb.org/cs/BlobServer?blobkey=id\&blobnocache=true\&blobwhere=1175823287357\&blobheade $\underline{\mathrm{r}=\text { application } \% 2 \mathrm{Fpdf} \& \text { blobcol=urldata\&blobtable=MungoBlobs. }}$.
} 
employee) stock options to which they were referring were easily tradable, relatively short-term in duration (say 10 days), and with a contract-defined exercise date. ${ }^{77}$

Employee stock options have none of these attributes. They cannot be traded, they typically expire in ten years from the grant date, and they are exercisable at the discretion of the option holder on any chosen business day or days over a period of between six and nine years from the vesting date to the expiration date of the contractual term. What is more, the employee will only retain the right to exercise the option if he or she remains employed by the particular firm that granted the option - a highly uncertain proposition in New Economy high-tech companies in which the very reason for the widespread introduction of broad-based stock-option plans in the 1980s was to induce professional, technical and administrative employees to give up secure employment in Old Economy companies.

As for future stock prices, which for any given company clearly cannot be known at the grant date, even for one hour into the future during trading, the critical BSM assumption is that stock prices follow a "random walk" that reflects an underlying log-normal probability distribution function. ${ }^{78}$ Put simply, BSM assumes that the probability of very small changes in stock prices is very high while the probability of very large changes is very low. In practice, this formulation of expected stock-price movements ignores the roles of innovation, speculation, and manipulation as drivers of stock prices. Yet, as illustrated in Figure 2, since the 1990s stock-price movements of high-tech companies such as Intel, Microsoft, and Cisco a well as the NASDAQ stock exchange on which they are listed have been anything but random walks. Rather, we contend, the stock-price movements of these companies have been driven by combinations of innovation, speculation, and manipulation. ${ }^{79}$

Take the case of Cisco Systems, which did its IPO on NASDAQ on February 23, 1990. If one had bought $\$ 1,000$ worth of Cisco shares just after the IPO and had held on to them until the end of 2015, they could have then been sold for about $\$ 460,000 .{ }^{80}$ Meanwhile, however, as can be seen in Figure 2, during that quarter century, Cisco's stock price underwent dramatic fluctuations, driven primarily (although obviously not wholly) in different periods by innovation, speculation, and manipulation.

\footnotetext{
77 Fischer Black and Myron Scholes, “The Pricing of Options and Corporate Liabilities," Journal of Political Economy, 81, 3, 1973: 637-654; Robert C. Merton, "The Theory of Rational Option Pricing," Bell Journal of Economics and Management Science, 4, 1, 1973: 141-183. Intellectual histories of Black-Scholes-Merton option pricing models include Donald MacKenzie, An Engine, Not a Camera: How Financial Models Shape Markets, MIT Press, 2006, and Perry Mehrling, Fischer Black and the Revolutionary Idea of Finance, Wiley, 2011. See also Fox, The Myth of the Rational Market.

${ }^{78}$ Apostolou and Crumbley, "Accounting for Stock Options."

79 William Lazonick, "The New Economy Business Model and the Crisis of U.S. Capitalism," Capitalism and Society, 4, 2, 2009: Article 4.

80 Nathan Buehler, "If you had invested right after Cisco's IPO," Investopedia, November 30, 2015, at http://www.investopedia.com/articles/markets/113015/if-you-had-invested-right-after-ciscos-ipo.asp.
} 
Figure 2. Stock-price movements, Intel (INTC), Microsoft (MSFT), and Cisco (CSCO), and the NASDAQ Composite Index, and prime drivers of stock prices, March 26, 1990-June 30, 2016 (March 26, 1990=100)

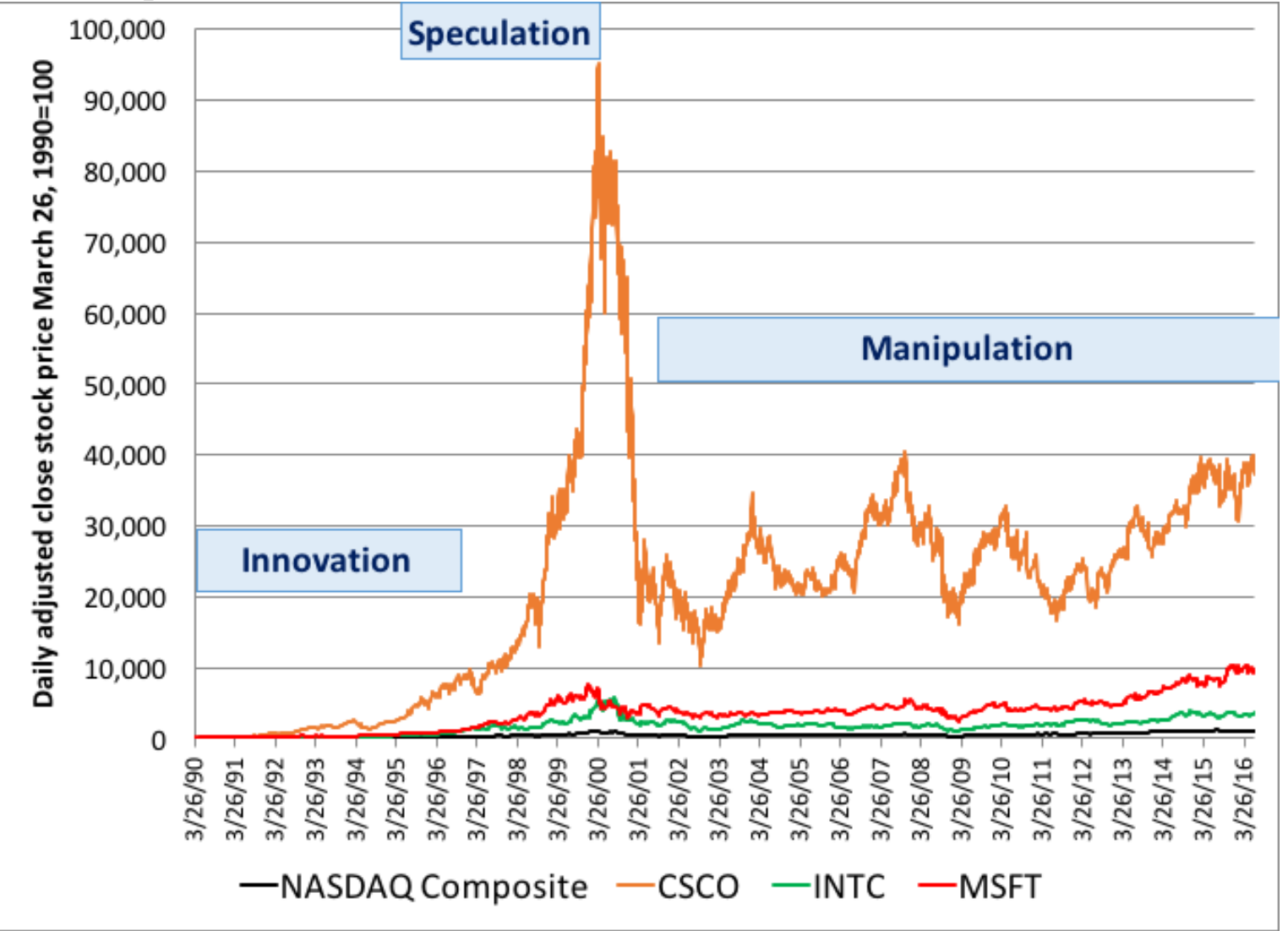

Source: Yahoo! Finance, daily data, adjusted close.

One can posit that during the first seven to eight years of its existence as a public company, innovation was the primary driver of the increase in Cisco's stock price as stock-market traders observed, after the fact, that the company was generating high levels of profit by becoming the dominant competitor in the booming Internet equipment market. In October 2008, at the end of this innovation phase, Charles O'Reilly, a professor at Stanford Business School, published a case that began with the statement, "Cisco is a $\$ 6$ billion high technology stealth company, largely unknown to the general public." 1

From November 1998 to March 2000, however, this "largely unknown" company was the focus of intense stock-market speculation, with its stock price rising by about seven times, giving Cisco the highest market capitalization in the world in March 2000. In May 2000, Thomas Donlan, a Barron's editor, calculated that to justify its stock price, which stood at 190 times earnings, Cisco would have to increase its 1999 profits of $\$ 2.5$ billion to $\$ 2.5$ trillion by $2010 !^{82}$

81 Charles A. O’Reilly, “Cisco Systems: The Acquisition of Technology is the Acquisition of People," Stanford Business School Case HR10, Graduate School of Business, Stanford University, October 1998.

82 Thomas G. Donlan, “Cisco's bids: Its growth by acquisition will cause problems.” Barron's, May 8. 2000: 31-34. 
This speculation had a profound impact on stock-based pay. Cisco CEO John Chambers received total compensation of $\$ 121.7$ million in 1999 and $\$ 156.3$ million in 2000 , with over 99 percent in each year coming from realized gains from exercising stock options. Cisco's other four highest-paid executives averaged \$25.9 million in 1999 (96 percent from options) and $\$ 38.0$ million in 2000 (97 percent from options). Indeed, with its broadbased stock-option plan, the average realized gains from exercising stock options at Cisco was (not including the highest-paid named executives) an estimated $\$ 193,500$ across an average of 18,000 employees in 1999 and $\$ 290,900$ across an average of 27,500 employees in $2000 .^{83}$

Then, with the bursting of the Internet bubble, between March 2000 and September 2001, Cisco's stock price plunged by 85 percent, at which point the company entered into the manipulation phase of its stock-price determination as it began doing stock buybacks. Cisco repurchased $\$ 1.9$ billion in fiscal 2002 (year ending July 27, 2002). \$6.0 billion in 2003, $\$ 9.1$ billion in 2004, and $\$ 10.2$ billion in 2005. Since then through 2015, Cisco's buybacks have ranged from a high of $\$ 10.4$ billion in 2008 to a low of $\$ 3.6$ billion in 2009. From 2002 through the third quarter of 2016, Cisco expended $\$ 96.7$ billion on repurchases, equal to 97 percent of its net income, while since 2011 also paying $\$ 16.8$ billion in dividends. The purpose of these massive buybacks has been to manipulate Cisco's stock price, enhancing the realized gains from stock options, especially for those executives who have been able to take advantage of the price boosts through the timing of their option exercises and stock sales.

The dramatic rise and fall of Cisco's stock price in the Internet boom and bust make the stock-price movements of Intel, Microsoft, and the NASDAQ Composite Index, as shown in Figure 2, appear as mere blips. Figure 3, with a more limited stock-price scale, shows similar price movements for Intel, Microsoft, and the NASDAQ Index. We posit that the stock prices of Intel and Microsoft followed a similar sequence of innovation, speculation, and manipulation phases over the past quarter century. One difference is that, with speculation in its stock rampant, Cisco did no buybacks in 1998-2000, whereas Intel did $\$ 15.4$ billion and Microsoft $\$ 10.3$ billion in these years, both companies trying to give their stock prices a boost, in part to offset the dilution of the companies' shareholdings as employees exercised their options and in part to try to maintain pace with Cisco's exploding stock price. Like Cisco, both Intel and Microsoft have done massive buybacks to manipulate their stock prices since the Internet boom turned to bust: $\$ 85.2$ billion by Intel from 2001 through the second quarter of 2016 and $\$ 164.7$ billion by Microsoft from 2001 through 2016.

Since the 1990s, as we have seen, the FASB and the SEC have been advocating BSM option-pricing models to provide fair-value estimates of employee stock-option compensation. Indeed, under FAS 123R, since 2006 the FASB and the SEC have required companies to use BSM-type estimates to record employee stock-option expenses in their $10-\mathrm{K}$ and 10-Q income statements. Yet these BSM-type models fail to capture the impacts of the three drivers of stock prices: innovation, speculation and manipulation.

83 See Lazonick, Sustainable Prosperity, pp. 48-66. 
Figure 3. Stock-price movements, Intel (INTC), Microsoft (MSFT) and the NASDAQ Composite Index, and prime drivers of stock prices, March 26, 1990-June 30, 2016 (March 26, 1990=100)

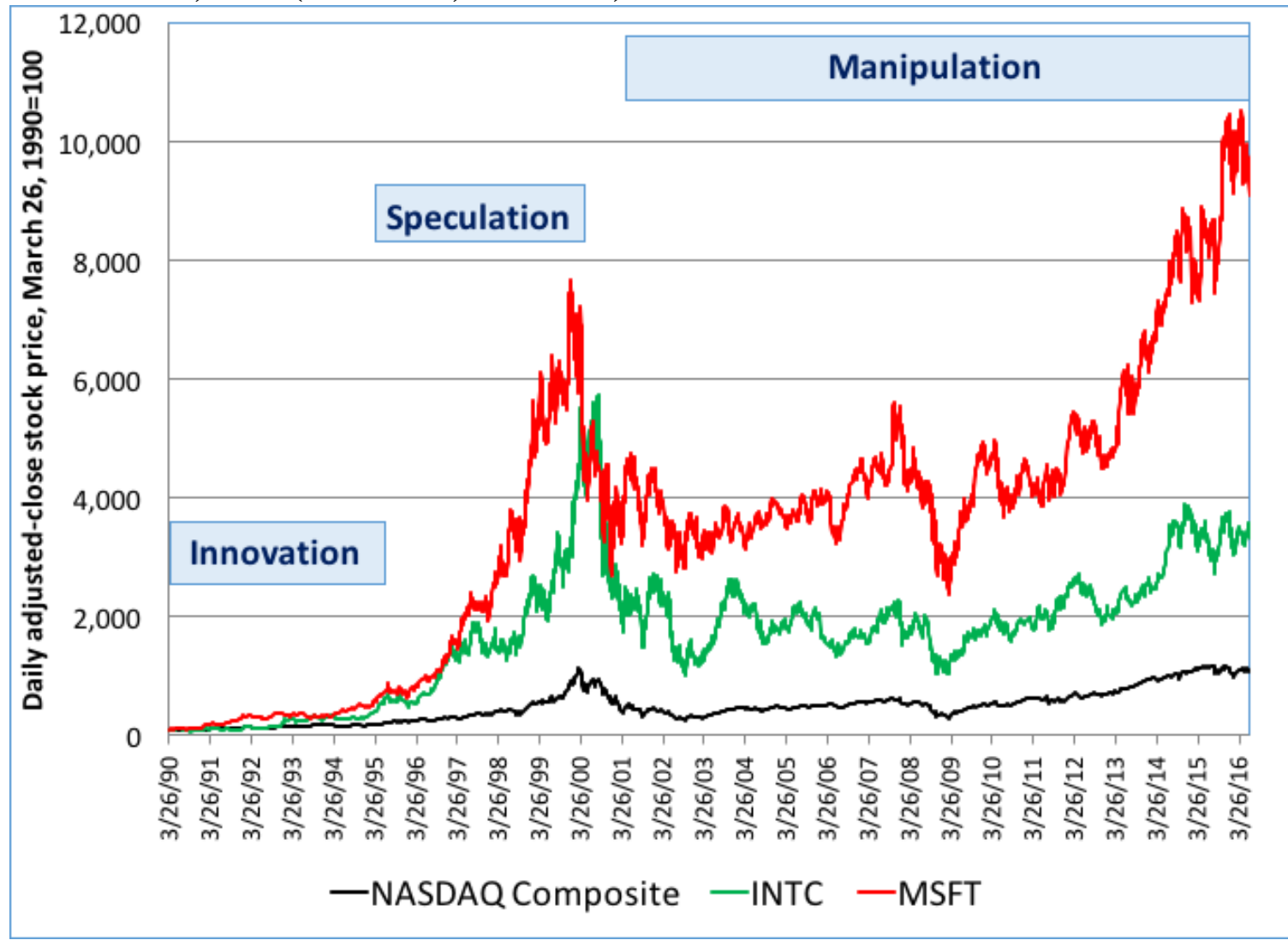

Source: Yahoo! Finance, daily data, adjusted close.

In assuming a log-normal distribution of stock prices, BSM cannot account for the emergence of uniquely innovative firms such as Intel, Microsoft, and Cisco that, through the development and utilization of productive capabilities, attain sustained competitive advantage and, with it, sustained increases in their stock prices. ${ }^{84}$ Nor can BSM models contemplate how speculation can build on innovation in generating stock-market bubbles that can make employee stock options highly lucrative when the stock-market booms, but that, by virtue of being speculative bubbles, will inevitably burst. ${ }^{85} \mathrm{BSM}$ models also do not have any conception of the possibility that corporate executives, incentivized by stockbased pay, will use their control over the allocation of corporate resources to augment their realized gains from stock options by doing massive buybacks to manipulate the company's stock price. ${ }^{86}$

Given the inherent deficiencies of BSM option-pricing models as applied to the drivers of the stock market and their impacts on the realized gains from stock-option compensation, we should not be surprised if the fair-value estimates generated by these models fail to

\footnotetext{
${ }^{84}$ For the lack of a theory of innovative enterprise in the neoclassical theory of the market economy, within which BSM models are rooted, see Lazonick, "Innovative Enterprise or Sweatshop Economics?".

85 See Lazonick, Sustainable Prosperity, chs. 2 and 6.

${ }^{86}$ See Lazonick, "Taking Stock"; Lazonick, "Profits Without Prosperity”; Lazonick, "Stock Buybacks.”
} 
predict actual realized gains. Yet widespread use of BSM on Wall Street and its promulgation in business schools and economics departments led the FASB and the SEC to sanction the BSM-type formula as a standard, and indeed even scientific, estimator of the "fair value" of stock options for accounting purposes. In sharp contrast to the longstanding IRS principle of "readily ascertainable fair value" for treating stock options as a compensation expense for tax purposes, the FASB and the SEC assume that a BSM formula generates an estimate that makes fair-value "ascertainable" at the option vesting date, using the grant-date stock price that constitutes the exercise price.

In pushing in the 1980s and early 1990s to replace ABP 25 with a BSM fair-value measure to be reported in corporate $10-\mathrm{K}$ and $10-\mathrm{Q}$ filings, the FASB ran into vigorous and vociferous opposition from the executives of the very same high-tech companies with broad-based stock-option plans that had raised the concerns of asset managers of the dilution of the shareholdings of the stocks in their funds' portfolios. Ignoring the fact that these high-tech companies were already benefiting from expensing their employees' realized gains from options in their IRS tax returns, the high-tech lobby warned that, if its member companies had to expense stock-based pay in their 10-K and 10-Q filings, the reductions in their reported earnings would result in declines in their stock prices, which would in turn impede their ability to attract, retain, motivate and reward their employees. ${ }^{87}$

Under FAS 123, the FASB expressed a preference for a BSM option-pricing model as the basis for reporting the estimated stock-option compensation expense. But from 1994 SEC disclosure rules required companies to report, but not necessarily record, an estimated total market value for stock options at the grant date under alternative scenarios of stockprice increases of five percent per year and ten percent per year over a contractual term of ten years. Under FAS 123R, however, the FASB and the SEC were in accord that, as of 2006, a company must not only record stock options as an expense in its financial statements but also use a BSM option-pricing model or, alternatively, a variant known as a Binomial or Lattice option-pricing model to estimate this expense. Thus, FAS 123R implemented the FASB-SEC fair-value project.

Compliant stock-option pricing models utilize inputs for stock price, term, volatility, a risk-free rate of return and dividend yield selected and disclosed by the company. The result is an option price that is, typically, a fraction of the grant-date price. The imaginary "spread" is not reconciled at a later date when and if the estimate either fails to meet the actual spread manifest in the realized gains that the executive actually receives or when and if the grant is forfeited or expires out of the money.

As the SEC's chief accountant put it in 2002, referring to the FASB-SEC fair-value project: "A question that the FASB must address is how to measure fair value when objective evidence does not exist for determining the assumptions from which to estimate

87 See George Sollman, Vice Chairman AEA Silicon Valley Council, "Silicon Valley Employee Stock Option Rally," memo to AEA HR company contacts, American Electronics Association, March 1, 1994, at http://3197d6d14b5f19f2f440-

5e13d29c4c016cf96cbbfd197c579b45.r81.cf1.rackcdn.com/collection/papers/1990/1994_0301_SiliconRally. pdf; Fox, "The next best thing"; Fox, "The amazing stock option"; Greg Hilt and Jacob Schlesinger, "Stock options come under fire in the wake of Enron's collapse," Wall Street Journal, March 26, 2002. 
fair value using a valuation model." ${ }^{88}$ Unfortunately, as we shall see in analyzing executive pay data, the FASB-SEC fair-value project and the BSM-type option-pricing models that it mandated through FAS 123R are responsible for the mismeasure of executive pay.

\section{ExecuComp and the measures (and mismeasures) of executive pay}

The S\&P ExecuComp database, drawn primarily from company proxy statements, has provided data for actual realized-gains and estimated fair-value measures of executive stock options and stock awards since $2006 .{ }^{89}$ For fiscal years 1992 through 2005, ExecuComp provides data on realized gains from stock options but not stock awards, which in any case have become most important in more recent years. ExecuComp, therefore, presently enables us to compare the compensation of named executives using the realized-gains and fair-value measures over the period 1992 to 2014. In this report, we have chosen to compare these measures for the 500 highest-paid executives in each year (eliminating a small number of extraordinarily highly compensated executives whose pay of $\$ 1$ billion or more significantly skews the average). First we provide a guide to the different measures of total executive compensation and its components in ExecuComp, and then we do the comparisons of the different measures of executive pay.

Constructing a measure of executive pay requires a judgment as to the components of pay that should count as part of a total as well an understanding of how those components of pay are defined. As we will see, by far the largest components of the compensation of the most highly paid U.S. corporate executives are the realized gains generated through stock options that they exercise and/or their stock awards that vest. As such, in conjunction with the numbers of shares of stock in their option and award grants, the most critical determinants of their total compensation are the level and rate of change of the company's stock price.

As part of the S\&P Capital IQ suite, ${ }^{90}$ the ExecuComp database provides data on executive pay from corporate proxy statements, beginning in 1992. These data became available in 1994 when the SEC required U.S. corporations to include the Summary Compensation Table and other pay information of "named" senior executives in their proxy statements, with the companies providing data for the two previous years. ${ }^{91}$ The SEC considers the Summary Compensation Table to be "the cornerstone of the SEC's required disclosure on executive compensation." 92 Yet, the ExecuComp user must be aware that the realized

\footnotetext{
88 Herdman, Testimony at SEC.

89 The ExecuComp database for the most recent fiscal year only becomes fully available in October of the following year.

${ }^{90}$ See http://www.spcapitaliq.com/our-capabilities/our-capabilities.html?product=compustat-ExecuComp.

91 The SEC required the Summary Compensation Table in the proxy statements of any company with fiscal year ending on December 15 or after, or with proxy statements issued on or after January 1, 1994. Companies provide data for the two previous years as well as the current one, and hence these data are available back to 1992.

92 U.S. Securities and Exchange Commission, "Fast Answers: Executive Compensation," at http://www.sec.gov/answers/execomp.htm. The SEC note goes on to say:" The Summary Compensation Table provides, in a single location, a comprehensive overview of a company's executive pay practices. It sets out the total compensation paid to the company's chief executive officer, chief financial officer and three other most
} 
gains on stock-based compensation, while reported in the proxy statement, do not appear in the Summary Compensation Table. Rather, they appear in a table entitled "Option Exercises and Stock Vested."

ExecuComp contains data on all of the companies included in the S\&P 1500 Stock Index, a composite index of the largest publicly-traded companies in the United States, predominantly listed on NYSE and NASDAQ. ${ }^{93}$ As a composite, the constituent companies change to some extent from year to year. Once a company is included in ExecuComp, $\mathrm{S} \& \mathrm{P}$ continues to input its new data in subsequent years even when the company is no longer in the Index. Hence, as shown in Table 2, there are more than 1,500 companies included in ExecuComp in any given year.

In ExecuComp, companies with a fiscal year ending between January 1 and June 30 are included in the database for the previous data year (for example, a company filing its proxy statement for the fiscal year ending on June 30, 2014, would be included in the 2013 dataset). S\&P inputs data to the ExecuComp database as the information is made public, with the full dataset for the most recent data year becoming available in the fourth quarter of the following calendar year (for example, complete data for 2014 became available during October 2015). ExecuComp data are frequently updated, and we have found that updates increase the sample size of the latest data year and change the sample size of the prior two years. The comparability of studies that make use of ExecuComp data for recent years depends to an extent on whether these studies analyze identical versions of the database.

The SEC currently requires a publicly listed company based in the United States to disclose compensation details for the chief executive officer (CEO), chief financial officer (CFO), and three other most highly paid executives, ranked by fair-value measures. The most highly paid named executives aside from the $\mathrm{CEO}$ and $\mathrm{CFO}$ are determined according to the convention of the Summary Compensation Table, which includes as part of total compensation the estimated fair value of stock options and stock awards that vested in that year for that executive and (since 2006) were expensed by the company in its $10-\mathrm{K}$ and $10-\mathrm{Q}$ financial statements. In addition, a variable that measures the change in the value of the executive's pension is included as part of total compensation but is not included in the selection of a named executive.

highly compensated executive officers for the past three fiscal years. The Summary Compensation Table is then followed by other tables and disclosure containing more specific information on the components of compensation for the last completed fiscal year. This disclosure includes, among other things, information about grants of stock options and stock appreciation rights; long-term incentive plan awards; pension plans; and employment contracts and related arrangements. In addition, the Compensation Discussion and Analysis section provides narrative disclosure explaining all material elements of the company's executive compensation programs."

93 S\&P states that the S\&P 1500 covers 90 percent of the market capitalization (the value of corporate stock) in the U.S. economy: http://us.spindices.com/indices/equity/sp-composite-1500. 
Table 2: Numbers of companies and executives in the ExecuComp database, 1992-2014

\begin{tabular}{|rrrc}
\hline Year & $\begin{array}{r}\text { Number of } \\
\text { companies }\end{array}$ & Number of executives & $\begin{array}{c}\text { Average number of named } \\
\text { executives per company }\end{array}$ \\
\hline $\mathbf{1 9 9 2}$ & 1,571 & 8,012 & 5.1 \\
$\mathbf{1 9 9 3}$ & 1,682 & 9,740 & 5.8 \\
$\mathbf{1 9 9 4}$ & 1,749 & 10,591 & 6.1 \\
$\mathbf{1 9 9 5}$ & 1,849 & 11,026 & 6.0 \\
$\mathbf{1 9 9 6}$ & 1,977 & 11,540 & 5.8 \\
$\mathbf{1 9 9 7}$ & 2,037 & 11,931 & 5.9 \\
$\mathbf{1 9 9 8}$ & 2,071 & 12,490 & 6.0 \\
$\mathbf{1 9 9 9}$ & 1,954 & 12,074 & 6.2 \\
$\mathbf{2 0 0 0}$ & 1,846 & 11,448 & 6.2 \\
$\mathbf{2 0 0 1}$ & 1,848 & 11,304 & 6.1 \\
$\mathbf{2 0 0 2}$ & 1,886 & 11,486 & 6.1 \\
$\mathbf{2 0 0 3}$ & 1,937 & 11,738 & 6.1 \\
$\mathbf{2 0 0 4}$ & 1,879 & 10,853 & 5.8 \\
$\mathbf{2 0 0 5}$ & 1,763 & 9,350 & 5.3 \\
\hline $\mathbf{2 0 0 6}$ & 1,931 & 10,880 & 5.6 \\
$\mathbf{2 0 0 7}$ & 2,178 & 12,320 & 5.7 \\
\hline $\mathbf{2 0 0 8}$ & 2,095 & 11,792 & 5.6 \\
$\mathbf{2 0 0 9}$ & 2,052 & 11,226 & 5.5 \\
\hline $\mathbf{2 0 1 0}$ & 2,013 & 10,842 & 5.4 \\
\hline $\mathbf{2 0 1 1}$ & 1,966 & 10,576 & 5.4 \\
$\mathbf{2 0 1 2}$ & 1,916 & 10,320 & 5.4 \\
\hline $\mathbf{2 0 1 3}$ & 1,862 & 9,983 & 5.4 \\
$\mathbf{2 0 1 4}$ & 1,820 & 9,468 & 5.2 \\
\hline
\end{tabular}

Source: Standard and Poor's ExecuComp database, retrieved April 26, 2016.

Prior to 2006 the requirement was that compensation details of the CEO and four other most highly paid executives had to be disclosed. When an executive who would be included among the "top five" based on annual compensation either joins the company or leaves the company during the fiscal year, he or she is also included among the named executives. In addition, any person who held the CEO position during the year is named. As a result, as shown in Table 2, a company may provide compensation information for more than the minimum of five executives in any given year. When an executive is named in any given year, his or her compensation and its components are given for the previous two years as well. Note, however, that the realized gains on stock-based pay are made available only for those years in which the executive is named, but not for the two previous years.

As noted, the compensation formula used to determine the highest-paid named executive officers at a company is based upon estimated fair-value measures of stock based compensation, not actual realized gains. ${ }^{94}$ It is quite possible, therefore, that, besides the CEO and (from 2006) the CFO, an executive who was actually among the highest paid by realized gains in any given year might not be a named executive. It is also undoubtedly the

\footnotetext{
94 In addition, the SEC does not permit the net increase or decrease in pension values used to calculated total compensation to be used in the determination of who is selected as a named executive officer.
} 
case, as we illustrated earlier in this report, that, because each company must name only three executives besides the $\mathrm{CEO}$ and $\mathrm{CFO}$, many highly paid executives at highercompensation companies who are not named have higher levels of compensation than executives who are named by lower-compensation companies.

The ExecuComp database tracks 99 variables, including 18 company descriptors, 12 executive descriptors, and 69 compensation variables. The different ExecuComp measures of the total annual compensation of a given executive are derived from combinations of compensation variables that represent components of executive pay. Besides annual salaries, senior executives receive bonuses, stock-based pay, perquisites, and deferred compensation.

When compensation schemes are designed, some pay components are tied to company financial performance metrics, the most popular of which is EPS. ${ }^{95}$ Some pay components provide the executive with the opportunity of taking advantage of the tax code to reduce his or her tax payments for a given amount of compensation. Current tax law creates incentives for companies to base their executive compensation plans on "performance pay" schemes that rely on achieving financial targets. ${ }^{96}$

Making intelligent use of the ExecuComp database to measure executive compensation depends, therefore, on a working knowledge of a variety of pay components and how they are measured, followed by decisions about what components are to be included in calculating total compensation. There are two complications in ExecuComp that are of prime importance to the measure of executive pay: a) the distinction, as already discussed in detail, between actual realized-gains and estimated fair-value measures of stock-based compensation, including income from stock options and stock awards; and b) changes in the designation and construction of variables that represent components of total executive compensation instituted in fiscal 2006 as a result of concerns in Congress as well as at the SEC and the FASB about abuses in the setting, measurement, and transparency of executive pay. These changes were integrally related to the implementation of FAS 123R, discussed earlier, which requires corporations to record stock-based compensation as an expense in their $10-\mathrm{K}$ and $10-\mathrm{Q}$ income statements.

Table 3 details eight different definitions of total executive compensation, showing the constituent components for each. In presenting ExecuComp, S\&P provides five different definitions of total compensation, labeled TDC1, TDC2, TOTAL_SEC, TOTAL_ALT1, and TOTAL_ALT2. S\&P uses the labels TDC1 and TDC2 for the entire period 1992 through 2014, with TDC1 containing fair-value measures of both stock options and stock

95 For instance, the Harvard Law School Forum on Corporate Governance, "CEO and Executive Compensation Practices: 2015 Edition" at https://corpgov.law.harvard.edu/2015/09/15/ceo-and-executive-compensationpractices-2015-edition/ points to both EPS and cash flow as dominant metrics. Pretax earnings and total shareholder return are also popular. See Gretchen Morgenson, "Pay for performance? It depends on the measuring stick," New York Times, April 12, 2014, at http://www.nytimes.com/2014/04/13/business/pay-forperformance-it-depends-on-the-measuring-stick.html?_r=2.

96 IRC 162(m) "excessive compensation", signed into law in 1994, outlines the deductibility of corporate compensation, limiting it to \$1 million unless additional compensation is qualified as "performance pay", using one or more performance metrics, and that metric cannot be attainable independent of the employee. See, for example: https://www.irs.gov/pub/irs-drop/rr-08-13.pdf. 
awards and TDC2 containing a realized-gains measure of stock options and a fair-value measure of stock awards. ${ }^{97}$ As we detail in Table 4, the constituent components of ExecuComp's TDC1 and TDC2 measures were redefined in 2006, and hence ExecuComp errs in labeling these total compensation series TDC1 and TDC2 across both the subperiods 1992-2005 and 2006-2014. To correct this error, we have created the total compensation labels TDC1(R) to replace ExecuComp's TDC1 and TDC2(R) to replace TDC2 from 2006. We then want a TDC measure that includes realized-gains variables for both stock options and stock awards from 2006, and for that purpose have created TDC3, which can then be compared with TDC1(R) and TDC2(R), isolating the stock-based pay measures as the only differences across these three post-2005 series.

TOTAL_SEC, TOTAL_ALT1 and TOTAL_ALT2 are definitions of total compensation introduced from 2006 that modify the basic formulae to capture the change in the value of an executive's pension (PENSION_CHG), a measure that was unavailable to the public before 2006. TOTAL_SEC, which from 2006 is the executive compensation included as an expense in a company's 10-K and 10-Q filings, uses fair-value measures of stock options and stock awards, valued at grant-date stock prices but recorded as a compensation expense only if and when an option or an award vests. TOTAL_ALT1 uses fair-value measures for stock options and stock awards valued at the grant dates irrespective of whether an option or an award eventually vests, while TOTAL_ALT2 uses the actual realized gains of these two stock-based components of executive pay.

TDC3 and TOTAL_ALT2 are directly comparable, with the only difference, as shown in Table 3, being the way in which deferred compensation is reported. TOTAL_SEC and TOTAL_ALT1 are also directly comparable, with the only difference being that TOTAL_SEC includes the estimated fair value only of those stock options and stock awards that vest, whereas TOTAL_ALT1 includes the fair value of all options and awards granted in a given year whether or not they vest.

Table 4 provides the definitions of the component variables that are included in each of the total compensation measures listed in Table 3. The second column of Table 4 gives the definition of those variables in use from 1992 through 2005, and the third column provides the definitions of new variables or changes in the definition of existing (1992-2005) variables introduced in fiscal 2006 (companies with fiscal years beginning July 1, 2005 or later).

\footnotetext{
97 Prior to 2006, companies were not required by the SEC to disclose a value for "total compensation" of the named executives. Standard \& Poor's therefore created TDC1 and TDC2 for the ExecuComp database, defining the components of total compensation for each of the two measures as shown in Table 3 .
} 
Table 3: Different measures of "total compensation" derived from the ExecuComp database and their components, 1992-2005 and 2006-2014

\begin{tabular}{|c|c|c|c|c|c|c|c|c|}
\hline $\begin{array}{l}\text { TOTAL EXECUTIVE } \\
\text { COMPENSATION MEASURES }\end{array}$ & TDC1 & $\begin{array}{c}\text { TDC1 } \\
(\mathrm{R})\end{array}$ & TDC2 & $\begin{array}{l}\text { TDC2 } \\
(\mathrm{R})\end{array}$ & TDC3 & $\begin{array}{c}\text { TOTAL } \\
\text { SEC } \\
\end{array}$ & \begin{tabular}{rl|} 
TOTAL \\
ALT1 \\
\end{tabular} & $\begin{array}{l}\text { TOTAL } \\
\text { ALT2 } \\
\end{array}$ \\
\hline $\begin{array}{ll}\text { Time period } \\
\end{array}$ & $\begin{array}{l}1992 \\
2005\end{array}$ & $\begin{array}{l}2006- \\
2014\end{array}$ & $\begin{array}{l}1992- \\
2005\end{array}$ & $\begin{array}{l}2006- \\
2014\end{array}$ & $\begin{array}{l}2006- \\
2014\end{array}$ & $\begin{array}{c}2006- \\
2014\end{array}$ & $\begin{array}{c}2006- \\
2014\end{array}$ & $\begin{array}{l}2006- \\
2014\end{array}$ \\
\hline \multicolumn{9}{|l|}{$\begin{array}{l}\text { NON-STOCKED BASED } \\
\text { COMPONENT VARIABLES }\end{array}$} \\
\hline SALARY & $\mathrm{X}$ & $\mathrm{X}$ & $\mathrm{X}$ & $\mathrm{X}$ & $\mathrm{X}$ & $\mathrm{X}$ & $\mathrm{X}$ & $\mathrm{X}$ \\
\hline BONUS [BONUS(R)] & $\mathrm{X}$ & $\mathrm{X}$ & $\mathrm{X}$ & $\mathrm{X}$ & $\mathrm{X}$ & $\mathrm{X}$ & $\mathrm{X}$ & $\mathrm{X}$ \\
\hline OTHCOMP [OTHCOMP(R)] & $\mathrm{X}$ & $\mathrm{X}$ & $\mathrm{X}$ & $\mathrm{X}$ & $\mathrm{X}$ & $\mathrm{X}$ & $\mathrm{X}$ & $\mathrm{X}$ \\
\hline LTIP & $\mathrm{X}$ & & $\mathrm{X}$ & & & & & \\
\hline NONEQ_INCENT & & $\mathrm{X}$ & & $\mathrm{X}$ & $\mathrm{X}$ & $\mathrm{X}$ & $\mathrm{X}$ & $\mathrm{X}$ \\
\hline DEFER_RPT_AS_COMP_TOT & & $\mathrm{X}$ & & $\mathrm{X}$ & $\mathrm{X}$ & & & \\
\hline PENSION_CHG & & & & & & $\mathrm{X}$ & $\mathrm{X}$ & $\mathrm{X}$ \\
\hline \multicolumn{9}{|l|}{$\begin{array}{l}\text { OPTIONS AND AWARDS: } \\
\text { ACTUAL REALIZED GAINS }\end{array}$} \\
\hline OPT_EXER_VAL & & & $\mathrm{X}$ & $\mathrm{X}$ & $\mathrm{X}$ & & & $\mathrm{X}$ \\
\hline SHRS_VEST_VAL & & & & & $\mathrm{X}$ & & & $\mathrm{X}$ \\
\hline \multicolumn{9}{|l|}{$\begin{array}{l}\text { OPTIONS AND AWARDS: } \\
\text { ESTIMATED FAIR VALUE }\end{array}$} \\
\hline OPTION_AWARDS_BLK_VALUE & $\mathrm{X}$ & & & & & & & \\
\hline OPTION_AWARDS_FV & & $\mathrm{X}$ & & & & & $\mathrm{X}$ & \\
\hline OPTION_AWARDS & & & & & & $\mathrm{X}$ & & \\
\hline RSTKGRNT & $\mathrm{X}$ & & $\mathrm{X}$ & & & & & \\
\hline STOCK_AWARDS_FV & & $\mathrm{X}$ & & $\mathrm{X}$ & & & $\mathrm{X}$ & \\
\hline STOCK_AWARDS & & & & & & $\mathrm{X}$ & & \\
\hline
\end{tabular}

Sources: ExecuComp database and the authors' creation of the new variables names TDC1(R),

TDC2(R), TDC3, BONUS(R), and OTHERCOMP(R), as explained in the text.

Table 4: ExecuComp definitions of component variables, 1992-2005 and from 2006

\begin{tabular}{|c|c|c|}
\hline Variable name & $\begin{array}{c}\text { Variable definition } \\
1992-2005 \\
\end{array}$ & $\begin{array}{c}\text { Definition of new variable in } 2006 / \\
\text { definition change from } 2006\end{array}$ \\
\hline \multicolumn{3}{|c|}{ NON-STOCK-BASED COMPONENT VARIABLES } \\
\hline SALARY & $\begin{array}{l}\text { Dollar value of the annual base salary paid } \\
\text { during the fiscal year. }\end{array}$ & No change. \\
\hline BONUS & $\begin{array}{l}\text { Dollar value of the annual bonus paid } \\
\text { during the fiscal year. The amount of cash } \\
\text { or non-cash unrestricted compensation } \\
\text { received during the fiscal year, if subject to } \\
\text { performance criteria not in excess of one } \\
\text { year and/or if contingent only on continued } \\
\text { employment. }\end{array}$ & $\begin{array}{l}\text { ExecuComp retains variable name BONUS, } \\
\text { but it should be BONUS(R) since elements } \\
\text { of BONUS are included in the new variable } \\
\text { NONEQ_INCENT, with BONUS(R) now } \\
\text { confined to annual non-performance } \\
\text { payments while NONEQ_INCENT is } \\
\text { contingent on achieving performance } \\
\text { targets, often extending beyond one year. }\end{array}$ \\
\hline OTHCOMP & $\begin{array}{l}\text { Sum total of the variables OTHANN and } \\
\text { ALLOTHTOT, which include other com- } \\
\text { pensation including perquisites, other } \\
\text { personal benefits, change-in-control or } \\
\text { termination payments, contributions to } \\
\text { 401(k) plans, life insurance premiums, } \\
\text { gross-ups and other tax reimbursements, } \\
\text { discounted share purchases, preferential or } \\
\text { above-market earnings on deferred or long- } \\
\text { term incentive compensation, etc. }\end{array}$ & $\begin{array}{l}\text { Variable name OTHCOMP is retained, but } \\
\text { should be OTHCOMP(R) since elements of } \\
\text { OTHCOMP may be included in DEFER_RPT_- } \\
\text { AS_COMP_TOT, a new variable from } 2006 . \\
\text { In principle, OTHCOMP(R) no longer } \\
\text { includes non-qualified deferred compensa- } \\
\text { tion on which taxes are paid only when } \\
\text { income is received. }\end{array}$ \\
\hline
\end{tabular}


Table 4: ExecuComp definitions of component variables, 1992-2005 and from 2006 (continued)

\begin{tabular}{|c|c|c|}
\hline LTIP & $\begin{array}{l}\text { Cash payment under long-term incentive } \\
\text { plan that may include restricted stock (or } \\
\text { stock "units") tied to performance criteria } \\
\text { such as cash flow or EPS over a period of } \\
\text { more than one year (usually three years). If } \\
\text { only restricted stock is given, company can } \\
\text { opt to disclose LTIP under RSTKGRNT. }\end{array}$ & $\begin{array}{l}\text { Discontinued and replaced by } \\
\text { NONEQ_INCENT. }\end{array}$ \\
\hline NONEQ_INCENT & & $\begin{array}{l}\text { New variable. Reports amount of all non- } \\
\text { equity compensation paid in that year that } \\
\text { is triggered by attainment of performance } \\
\text { target(s) defined by the incentive compen- } \\
\text { sation plan. NONEQ_INCENT excludes } \\
\text { stock-based pay, differentiating it from } \\
\text { LTIP but similar to elements of BONUS. }\end{array}$ \\
\hline $\begin{array}{l}\text { DEFER_RPT_AS_ } \\
\text { COMP_TOT }\end{array}$ & & $\begin{array}{l}\text { New variable. Prior to } 2006 \text { included in } \\
\text { OTHCOMP. Amount of non-qualified } \\
\text { deferred compensation paid in that year. }\end{array}$ \\
\hline PENSION_CHG & & $\begin{array}{l}\text { New variable. Composed of a) above- } \\
\text { market or preferential earnings from } \\
\text { deferred compensation plans and b) the } \\
\text { aggregate increase in the actual value of } \\
\text { defined benefit and other pension plans } \\
\text { during the year. Not used to identify the } \\
\text { highest-paid named executive officers, but } \\
\text { tracked after the fact. }\end{array}$ \\
\hline \multicolumn{3}{|c|}{ OPTIONS AND AWARDS: ACTUAL REALIZED GAINS } \\
\hline OPT_EXER_VAL & $\begin{array}{l}\text { Value realized from option exercises } \\
\text { during the fiscal year, based on the spread } \\
\text { between the exercise price and the market } \\
\text { price of the stock on the exercise date. }\end{array}$ & No change. \\
\hline SHRS_VEST_VAL & & $\begin{array}{l}\text { Value realized (number of shares times } \\
\text { vesting date price) on restricted stock } \\
\text { awards that vest during fiscal year, } \\
\text { including accumulated dividends if paid } \\
\text { over the vesting period. }\end{array}$ \\
\hline \multicolumn{3}{|c|}{ OPTIONS AND AWARDS: ESTIMATED FAIR VALUE } \\
\hline $\begin{array}{l}\text { OPTION_AWARDS } \\
\text { RPT_VALUE }\end{array}$ & $\begin{array}{l}\text { Estimated value of stock options granted as } \\
\text { reported, but not recorded, based on an } \\
\text { assumed stock-price appreciation at } 5 \% \text { or } \\
10 \% \text { per annum for } 10 \text { years. ExecuComp } \\
\text { collects only the } 5 \% \text { figure. Not used in } \\
\text { construction of any total compensation } \\
\text { measures. }\end{array}$ & $\begin{array}{l}\text { Replaced by OPTION_AWARDS, which is } \\
\text { used to record as well as report the grant- } \\
\text { date fair-value of options awarded using a } \\
\text { Black-Scholes-Merton (BSM) or Binomial } \\
\text { option-pricing model. }\end{array}$ \\
\hline $\begin{array}{l}\text { OPTION_AWARDS_ } \\
\text { BLK_VALUE }\end{array}$ & $\begin{array}{l}\text { Estimated value of stock options granted } \\
\text { during the year, using S\&P's Black-Scholes- } \\
\text { Merton methodology. }\end{array}$ & Replaced by OPTION_AWARDS_FV. \\
\hline OPTION_AWARDS_FV & & $\begin{array}{l}\text { Estimated fair value at grant date of all } \\
\text { stock options awarded during the fiscal } \\
\text { year, reported using BSM or Binomial } \\
\text { pricing model. Replaces } \\
\text { OPTION_AWARDS_BLK_VALUE. }\end{array}$ \\
\hline OPTION_AWARDS & & $\begin{array}{l}\text { Estimated fair value, using grant-date } \\
\text { price, of stock options that vest during the } \\
\text { fiscal year as reported and recorded by the } \\
\text { company in the Summary Compensation } \\
\text { Table using BSM or Binomial option pricing } \\
\text { model. }\end{array}$ \\
\hline
\end{tabular}


Table 4: ExecuComp definitions of component variables, 1992-2005 and from 2006 (continued)

\begin{tabular}{|l|l|l|}
\hline RSTKGRNT & $\begin{array}{l}\text { Value of restricted stock awarded during } \\
\text { fiscal year, determined at grant date as } \\
\text { share price times the number of shares } \\
\text { granted. }\end{array}$ & Replaced by STOCK_AWARDS_FV. \\
\hline STOCK_AWARDS_FV & & $\begin{array}{l}\text { Estimated fair value of } \text { all restricted stock } \\
\text { awarded during the fiscal year determined at } \\
\text { grant date as share price times the number of } \\
\text { shares granted. }\end{array}$ \\
\hline STOCK_AWARDS & $\begin{array}{l}\text { Estimated fair value, using grant-date price, } \\
\text { of stock awards that vested during the fiscal } \\
\text { year as reported and recorded by the } \\
\text { company in the Summary Compensation } \\
\text { Table. }\end{array}$ \\
\hline
\end{tabular}

The fair-value measures of stock-based pay used in TDC1, TDC1(R), TDC2 (for awards only), TDC2(R) (for awards only), TOTAL_SEC, and TOTAL_ALT1 are estimates of the prospective value of options or awards under various assumptions, depending on the particular estimation model deployed. The variables OPTION_AWARDS_BLK_VALUE, OPTION_AWARDS_FV, and OPTIONS_AWARDS are BSM-type estimates of stockoption compensation, calculated with assumptions made about the grant price, exercise price, dividend payments, the risk-free interest rate, the time to grant expiration, and the volatility of the stock price. In use from 1992 through 2005, OPTION_AWARDS_BLK_ VALUE is calculated according to S\&P's Black-Scholes methodology, while OPTION_AWARDS_FV, in use since 2006, is calculated and reported by the companies, and OPTION_AWARDS is the estimated fair value of vested options calculated and recorded by the companies as a compensation expense in their SEC filings, in accordance with FAS 123R.

RSTKGRNT and STOCK_AWARDS_FV are simply the number of shares granted times the stock price at the grant date, while the variable STOCK_AWARDS represents the number of shares granted times the stock price at the grant date recorded in the year that the stock award vests and is the estimated fair value of stock awards that companies now record as a compensation expense in their SEC filings. Since 2006 companies have reported STOCK_AWARDS_FV under the Grants of Plan-Based Awards Table, whereas from 1992 through 2005 S\&P collected RSTKGRNT from the Summary Compensation Table, which is now the location of STOCK_AWARDS. Prior to 2006 companies could choose to report restricted stock grants that had vested as part of LTIP, if those awards had not been previously reported as a restricted stock grant.

What, then, are the implications of using actual realized-gains versus estimated fair-value measures of executive stock-based pay? And how, in the changing regulatory environment of the 2000s, did the relation between the two measures change? Our empirical approach to answering these questions is to use ExecuComp to generate data on the 500 highestpaid corporate executives in the database for the various measures of total compensation and their components given in Tables 3 and 4 for each year in the period 1992-2014. 
Figure 4 shows total compensation for TDC2 for 1992-2005 along with the proportionate shares of the components making up TDC2. Stock-option income is measured by realized gains, which companies reported, but TDC2 uses RSTKGRNT as an estimate of stockaward income because before 2006 companies did not report the realized gains from stock awards. Figure 4 shows the importance of stock-based pay in total executive compensation. Over the period 1992-2005, realized gains from stock options ranged from 45 percent of total pay in 1994 , when average total compensation was $\$ 5.5$ million, its lowest level over the 14 years, to 80 percent in 2000, when average total compensation was $\$ 32.3$ million, its highest level. During this period stock awards, as measured by RSTKGRNT, ranged on average from six percent to 18 percent of total compensation.

Figure 4: Average total compensation by TDC2 and cumulative percentage shares of pay components, 500 highest-paid executives in each year, 1992-2005

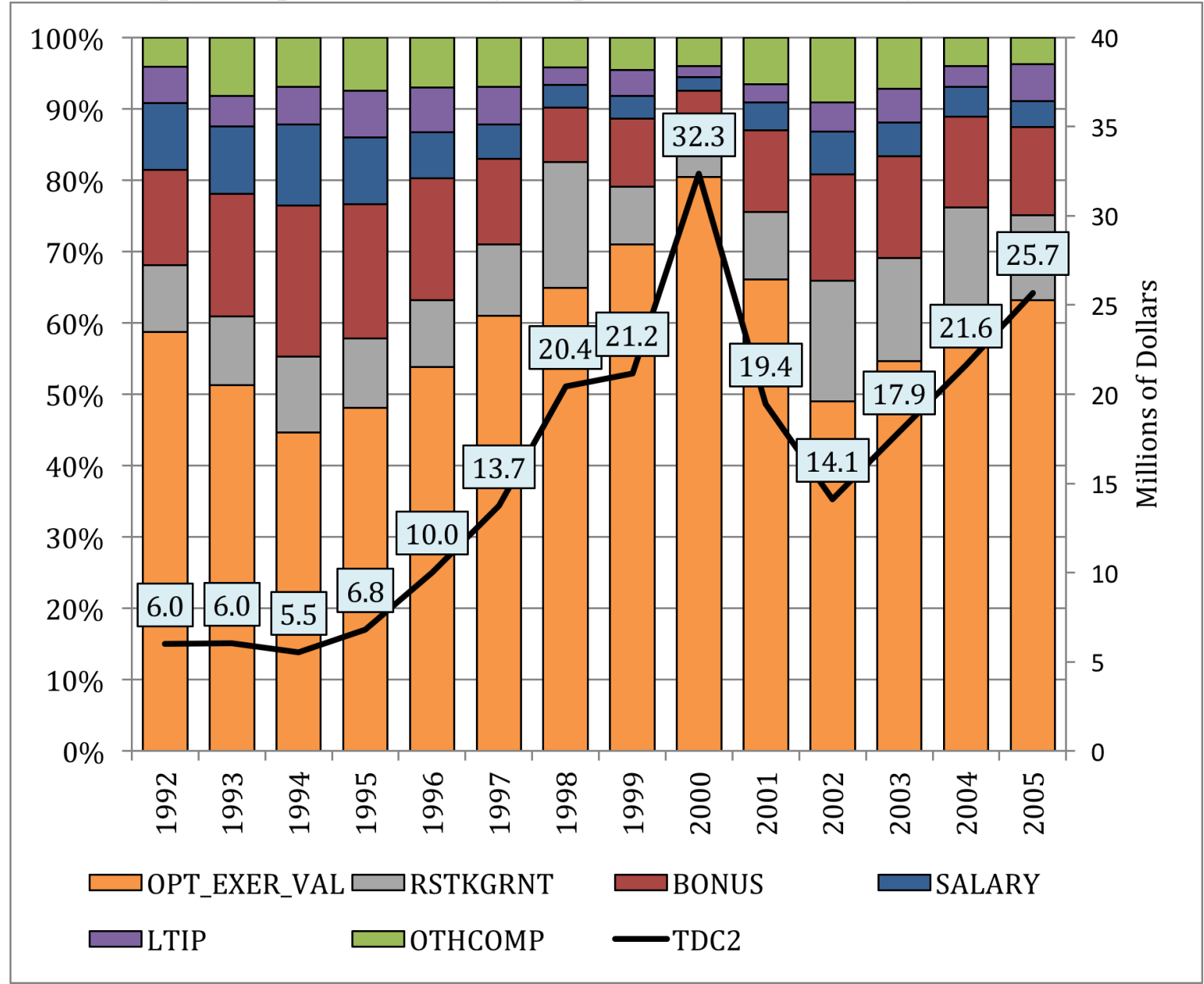

Source: Authors' calculations, ExecuComp data retrieved April 26, 2016.

In 2006 a realized-gains measure of stock awards became available, permitting the construction of the total direct compensation measure TDC 3 in which both components of stock-based compensation measure realized gains. Figure 5 shows that, as shares of TDC3, stock-option income ranged from 41 percent in 2009 and 2010 to 59 percent in 2007, while stock-award income ranged from 18 percent in 2006 to 41 percent in 2014. Combining the two stock-based components, they represented a low of 66 percent of 
TDC3 in 2009, when the stock market had plummeted, and a high of 84 percent in 2014, when the stock market was booming. In 2009 TDC3 of the 500 highest-paid executives averaged $\$ 14.7$ million but in 2007, 2012, and 2014, a rising stock market gave executives more than twice that amount. As shown in Figure 6, when the change in the value of a pension is included in the calculation of total compensation, yielding the total compensation measure TOTAL_ALT2, the figures on average annual compensation for the 500 highest-paid executives are from $\$ 0.5$ million to $\$ 1.3$ million higher than the TDC3 calculations.

Figure 5: Average total compensation by TDC3 and cumulative percentage shares of pay components, 500 highest-paid executives in each year, 2006-2014

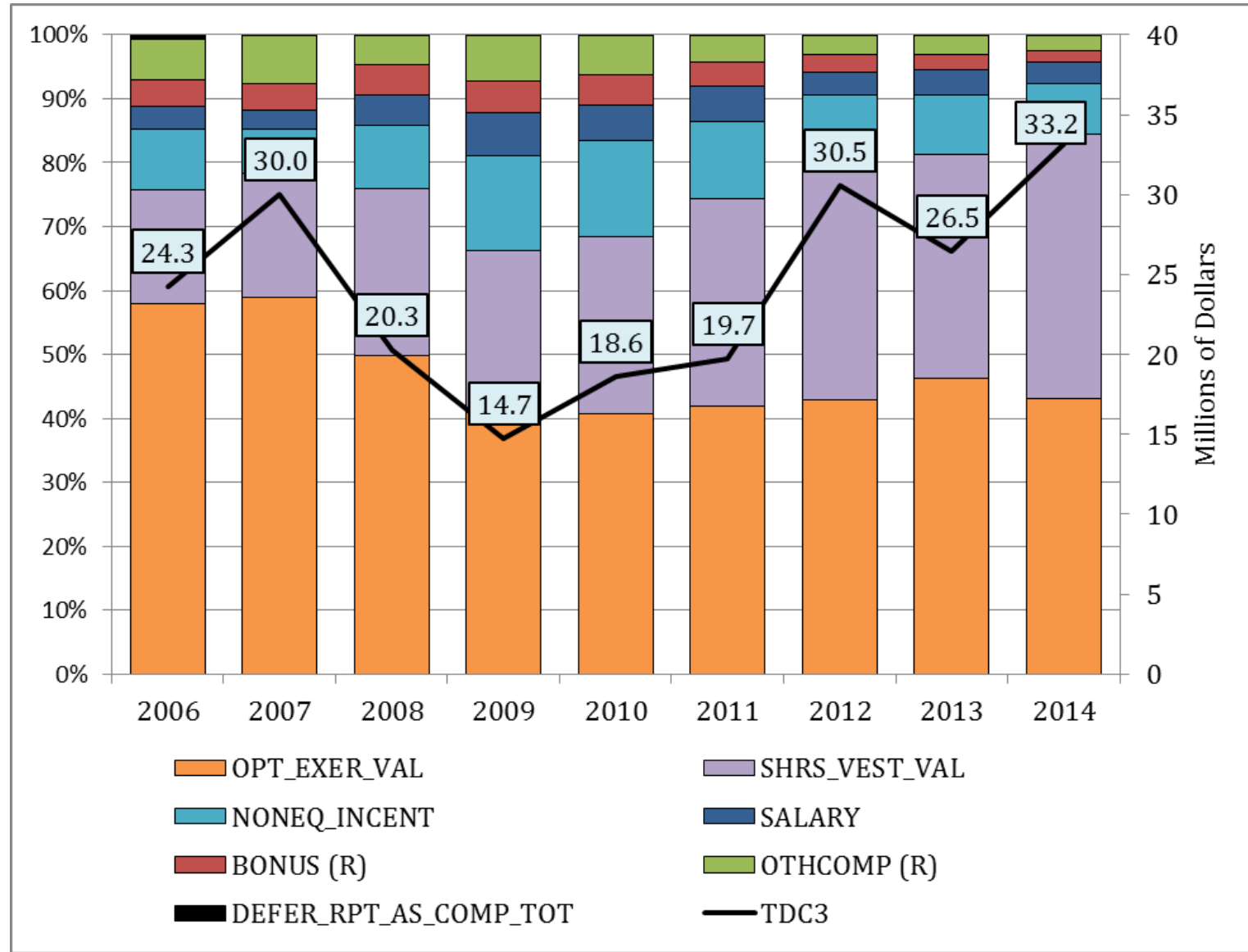

Source: Authors' calculations, ExecuComp data retrieved April 26, 2016.

Note: The following extraordinarily highly paid outliers, with $\$ 1$ billion or more in total compensation, have been removed: 2008, Austin Beutner, Evercore, \$1.4 billion; 2012, Richard Kinder, Kinder Morgan, \$1.1 billion, and Mark Zuckerberg, Facebook, \$2.3 billion; 2013, Mark Zuckerberg, \$3.3 billion; 2014, David Field, Entercom, \$1.5 billion. 
Figure 6: Average total compensation by TOTAL_ALT2 and cumulative percentage shares of pay components, 500 highest-paid executives in each year, 2006-2014

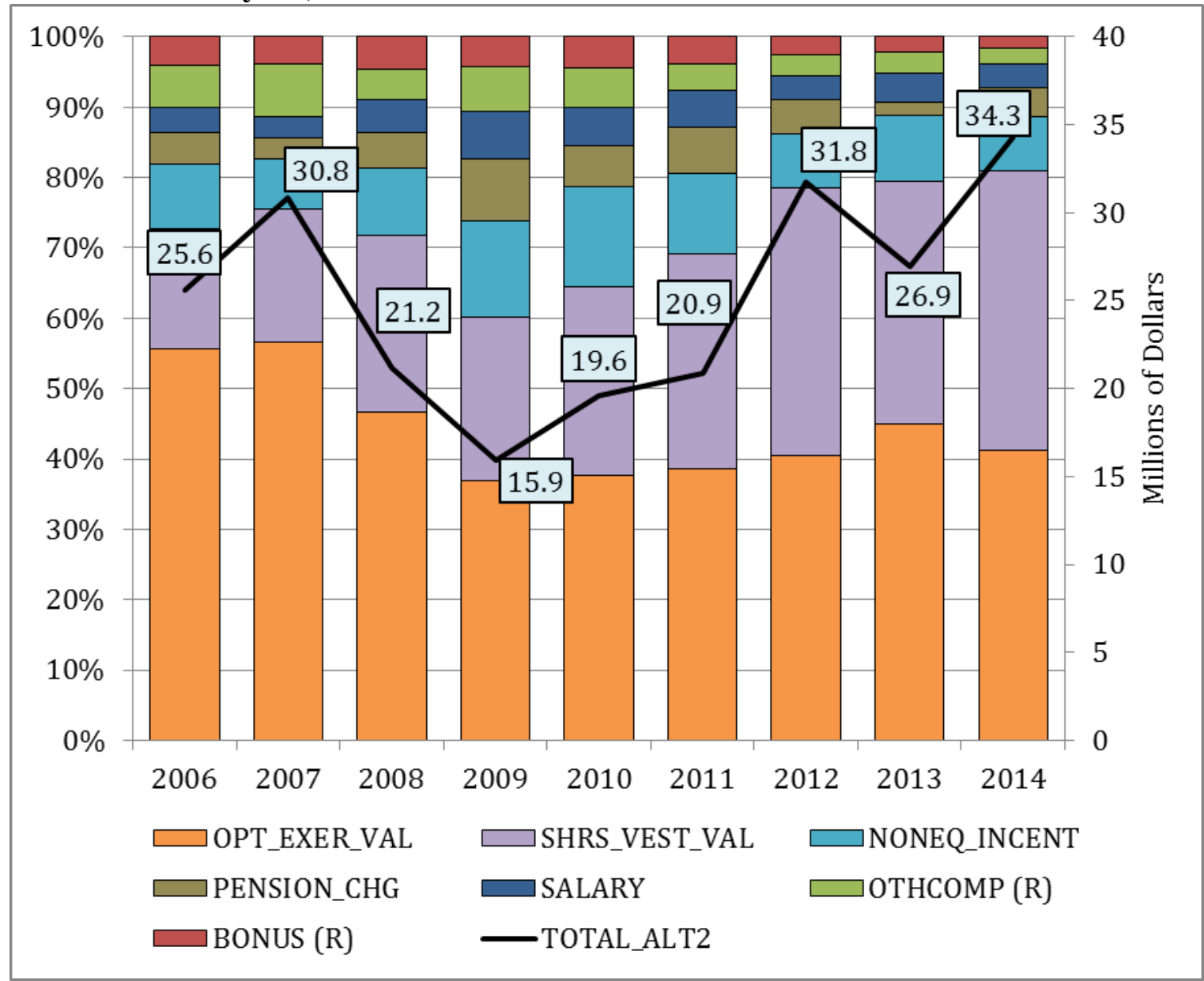

Source: Author's calculations, ExecuComp data retrieved April 26, 2016.

Note: The following extraordinarily highly paid outliers, with $\$ 1$ billion or more in total compensation, have been removed: 2008, Austin Beutner, Evercore, $\$ 1.4$ billion; 2012, Richard Kinder, Kinder Morgan, \$1.1 billion, and Mark Zuckerberg, Facebook, \$2.3 billion; 2013, Mark Zuckerberg, \$3.3 billion; 2014, David Field, Entercom, $\$ 1.5$ billion.

Figure 7 shows the difference between the fair-value and realized-gains measures of stock-option income for the 500 highest-paid executives by TDC1 from 1992 through 2005 and by TDC1(R) from 2006 through $2014 .{ }^{98}$ Note that from 1992 through 2002, the fair-value measure moves in the same directions as the realized-gains measure through

\footnotetext{
98 For the data year 2006, we removed executives in the top 500 with OPTION_AWARDS_BLK_VALUE data and included only those executives for whom a value was included for OPTION_AWARDS_FV. Doing so ensured conformity with the TDC1(R) and TDC2(R) definitions, as described. As a result, average pay of the top 500 was $\$ 15.6$ million for TDC1(R) and \$24.6 million for TDC2(R) in 2006. Had we not adjusted for executives with OPTION_AWARDS_BLK_VALUE data, the average total compensation would have been $\$ 17.5$ million for TDC1/TDC1(R) and \$27.5 million for TDC2/TDC2(R) in 2006. We displaced 82 executives who would otherwise have been included in the top 500 by TDC1, who averaged $\$ 20.7$ million in total compensation. We displaced 90 executives who would otherwise have been included in the top 500 by TDC2, who averaged $\$ 17.5$ million in total compensation.
} 
boom (to 2000) and bust (2001-2002). In 2003, however, estimated fair value continues to decline whereas actual realized gains rise.

This divergence between estimated fair value and actual realized gains continues after 2003 , with the fair-value measure showing virtually no volatility through 2014 , whereas the realized-gains measure - the actual stock-based income that the 500 highest-paid executives by TDC1 and TDC1(R) received - is not only far greater than the estimated fair-value measures in 2005-2007 and 2012-2014, but also shows considerable volatility, reflecting movements in stock prices over this period. Indeed, the only year from 2003 through 2014 in which the fair-value and realized-gains measures exhibit convergence is in 2009 , when the stock markets had collapsed.

Figure 7: Fair-value and realized-gains measures of executive stock-option income, by TDC1, 1992-2005, and TDC1(R), 2006-2014, 500 highest-paid executives in each year

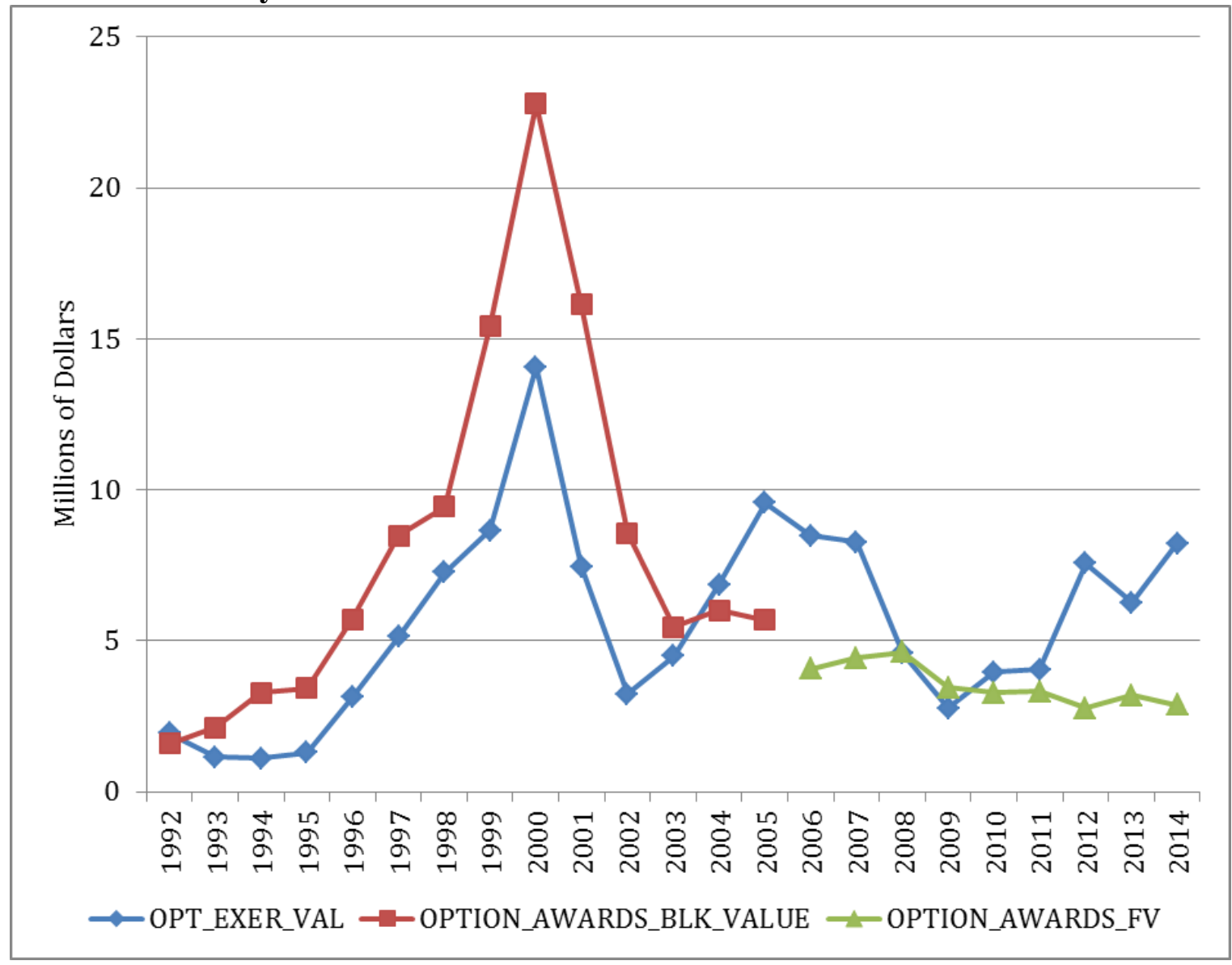

Source: Authors' calculations, ExecuComp data retrieved April 26, 2016.

Similarly, Figure 8 shows estimated fair-value and actual realized-gains of the stockoption component of executive compensation for the 500 highest-paid executives by TDC2 (1992-2005) and TDC2(R) (2006-2014). As in Figure 7, the realized-gains and fairvalue measures of stock-option income move in the same direction, through boom and bust, from 1992 through 2002, but then diverge. By virtue of the definitions of total direct 
compensation - TDC2 and TDC2(R) - selected for determining the 500 highest-paid executives in Figure 8, the actual realized gains from exercising stock options are consistently greater than the estimated fair-value measure (and vice versa in Figure 7). In Figure 8, average realized gains from exercising stock options for the top 500 highest-paid executives by TDC2 were $\$ 26$ million in 2000, but only $\$ 14$ million in Figure 7, which shows the 500 highest-paid executives by TDC1. In fact, annually, realized gains from options are typically around twice as high when the 500 highest paid are sorted by TDC2 and TDC2(R) as compared with TDC1 and TDC1(R).

Figure 8: Fair-value and realized-gains measures of executive stock-option income, by TDC2, 1992-2005, and TDC2(R), 2006-2014, 500 highest-paid executives in each year

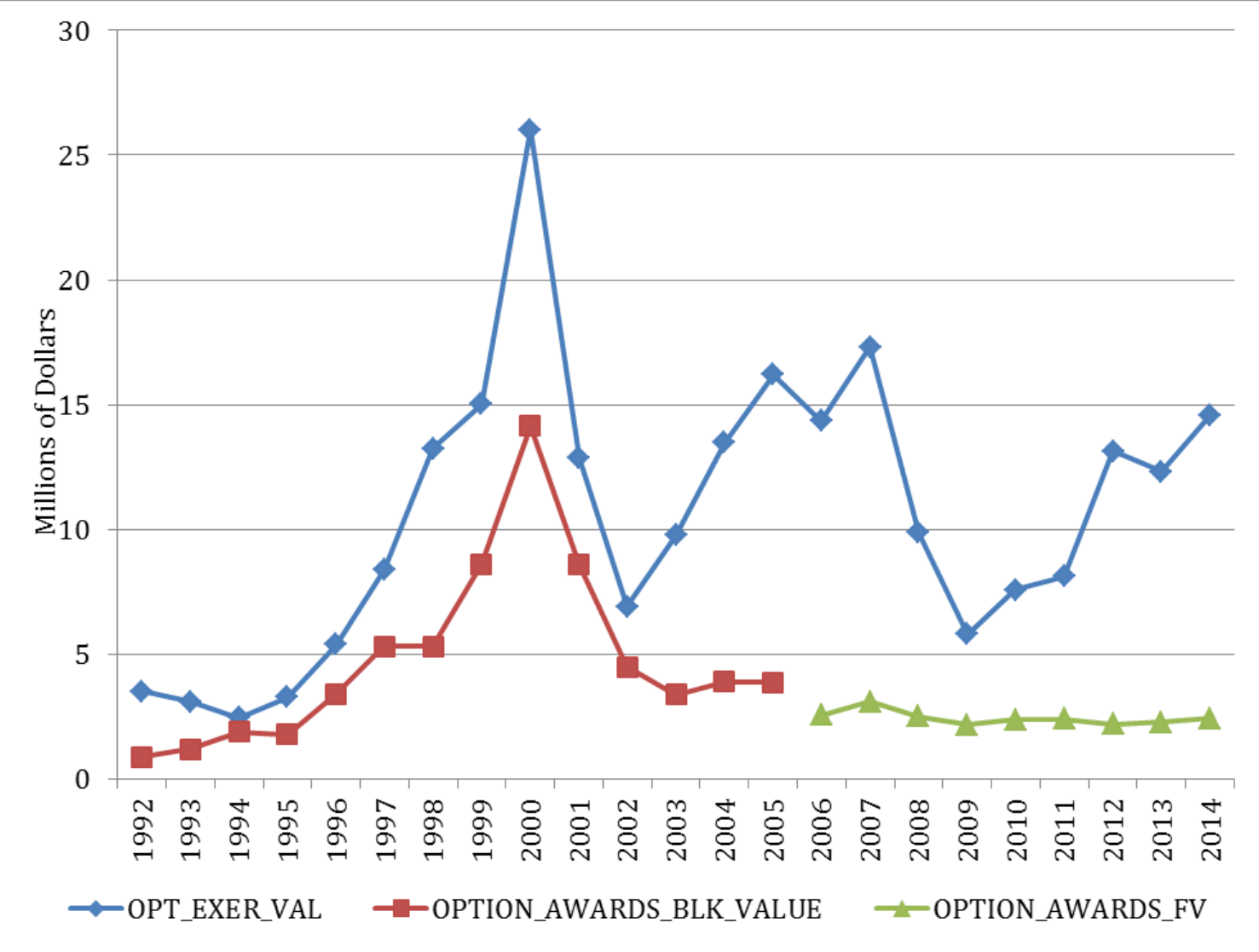

Source: Authors' calculations, ExecuComp data retrieved April 26, 2016.

Recall from Table 3 that the TOTAL_ALT2 makes use of the realized gains measure of stock-based pay while TOTAL_SEC uses the estimated fair value of stock-based pay, as recorded by companies in their $10-\mathrm{K}$ and $10-\mathrm{Q}$ filings. Figure 9 selects the 500 highestpaid executives for 2006 through 2014 by TOTAL_ALT2, and compares their average realized gains from exercising stock options OPT_EXER_VAL with the fair-value measures OPTION_AWARDS_FV (the total grant-date value of new options awards) and OPTION_AWARDS (the total grant-date value of option awards that vested, and that companies deduct from earnings in calculation of their net income in their 10-K and 10-Q filings with the SEC). The realized gains from stock options - the amounts that these 
executives actually received as personal income - are six times the fair-value estimates in 2007 and 2014, years in which the booming stock markets were reaching a peak. But even in 2009, when the stock markets had collapsed, the realized-gains measure is still 2.7 times the fair-value measure that companies record as the stock-option compensation of these executives.

Figure 9: Fair-value and realized-gains measures of executive stock-option income, by TOTAL_ALT2, 2006-2014, 500 highest-paid executives in each year

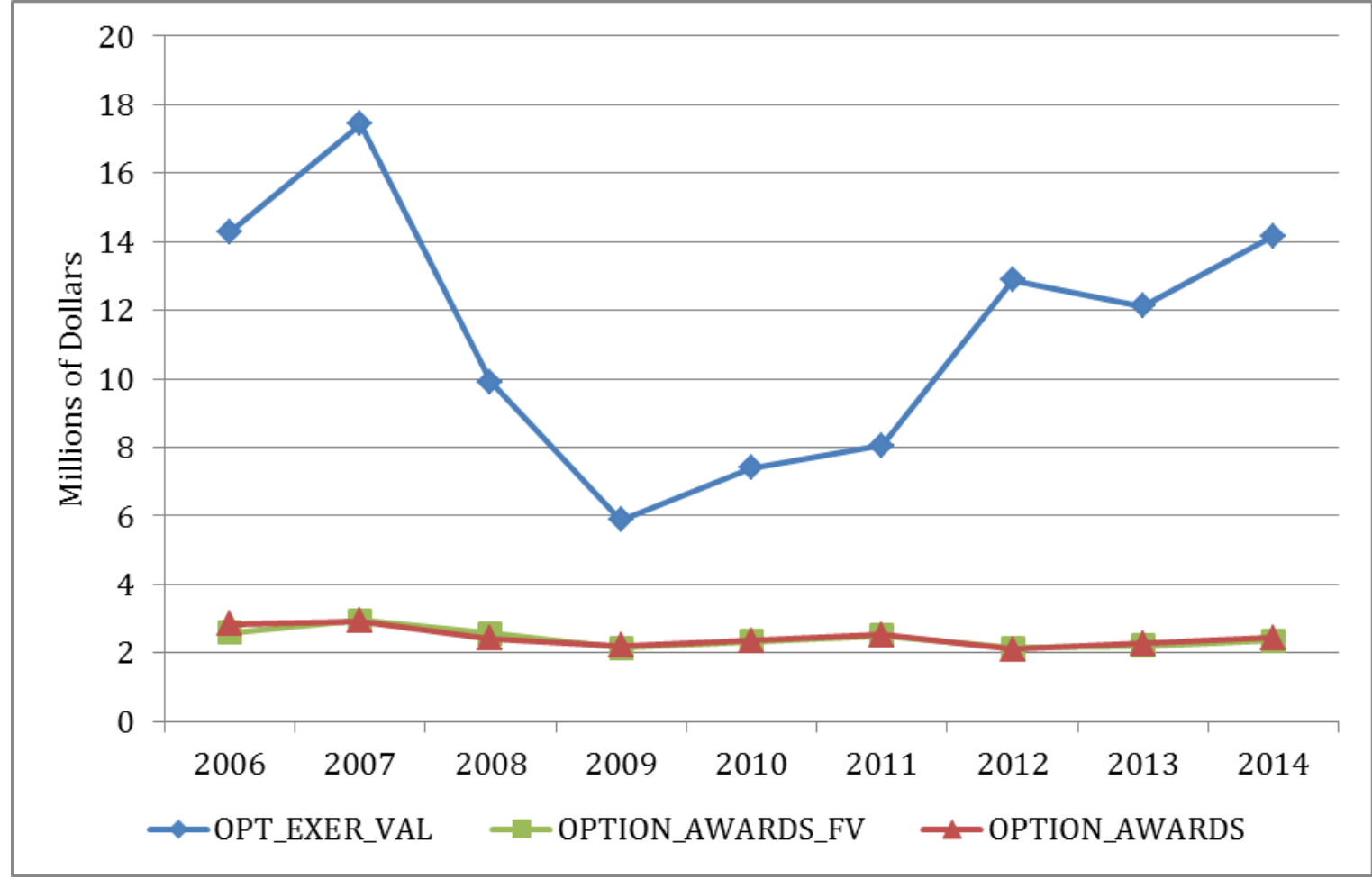

Source: Authors' calculations, ExecuComp data retrieved May 26, 2016.

In the period 2006-2014, it becomes possible to calculate the total direct compensation of the 500 highest-paid executives using realized gains from stock awards as well as stock options. As already discussed, prior to 2006 companies did not report a realized-gains measure of income from stock awards. As shown in Figure 10, from 2006 through 2014 realized gains from stock awards for the 500 highest paid by TOTAL_ALT2 are consistently greater than the fair-value measures of stock awards, with STOCK_AWARDS_FV and STOCK_AWARDS showing less volatility than SHRS_VEST_VAL. In 2014, the realized-gains measure of stock-award income is 2.4 times the fair-value measure. The two measures come closest in 2009 , when the stock market slumped sharply, with the actual realized gains from stock awards averaging \$3.7 million and the estimated fair value of stock awards averaging \$3.3 million. 
Figure 10: Fair-value and realized-gains measures of executive stock-award income, by TOTAL_ALT2, 2006-2014, 500 highest-paid executives in each year

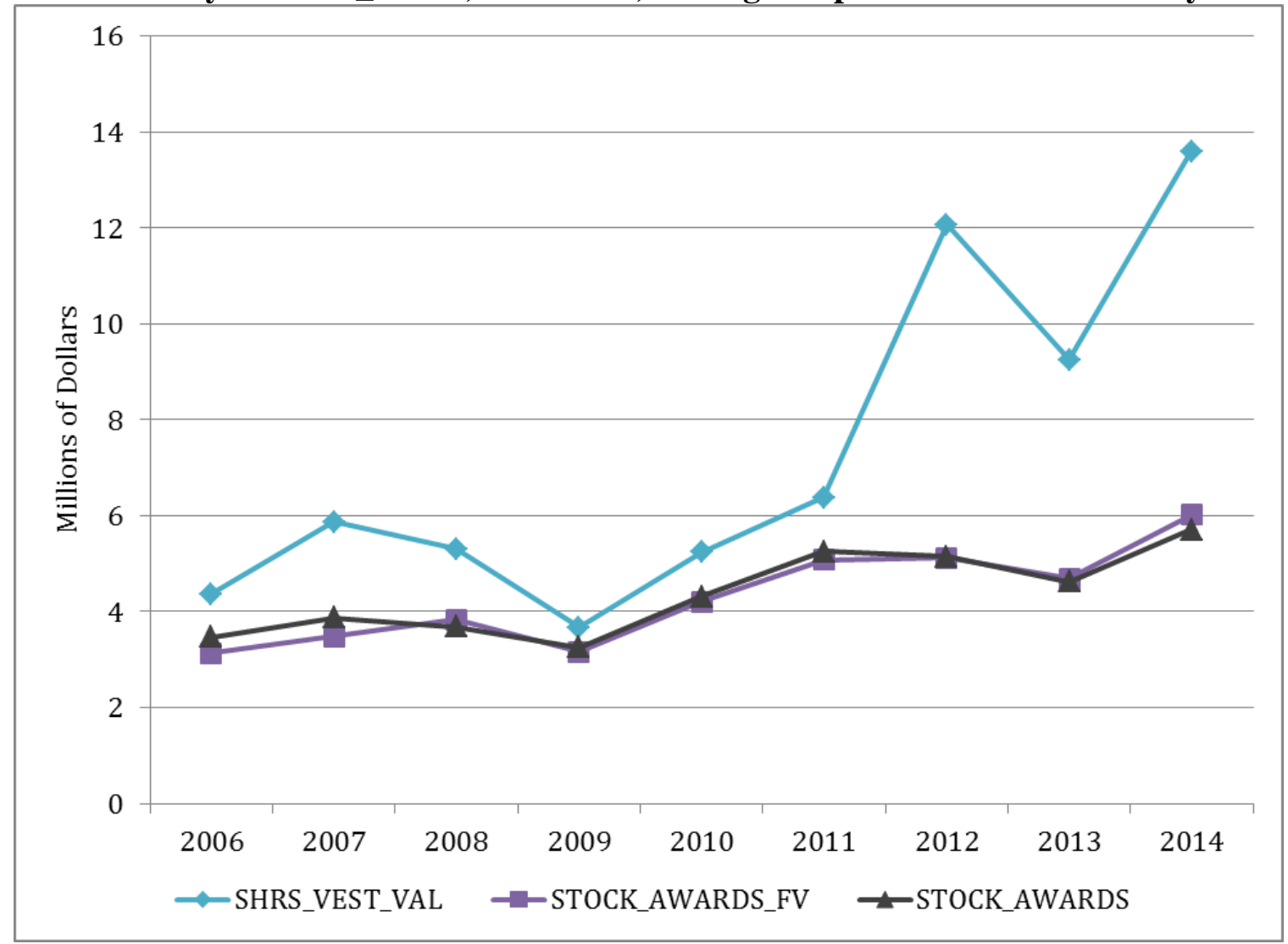

Source: Authors' calculations, ExecuComp data retrieved May 26, 2016.

Figure 11 sums up this analysis of the different measures of total compensation for the 500 highest-paid executives over the period 1992 to 2014. Comparing TDC1 and TDC2 for the years 1992 through 2005, we see that these two measures of total executive pay tracked each other from 1992 through 2002, but then diverged from 2003 through 2005. The only difference between TDC1 and TDC2 is the measure of the stock-option pay component, with TDC1 using the estimated fair-value measure and TDC2 the actual realized-gains measure. The comparison between TDC1(R) and TDC2(R) from 2006 continues this divergence, notwithstanding the steep fall in TDC2(R) in 2009, with the stock-market crash. From 2003 through 2014, the TDC1/TDC1(R) series shows much lower values and much less volatility than the TDC2/TDC2(R) series, with the gaps between the fair-value and realized-gains measures of total direct compensation becoming enormous in years when the stock market was booming. TDC3, which includes the realized-gain measure for stock awards as well as stock options, further accentuates the boom-year gaps when compared with TDC2(R). 
Figure 11: Comparing fair-value and realized-gains measures of average total direct compensation of the 500 highest-paid executives, 1992-2014

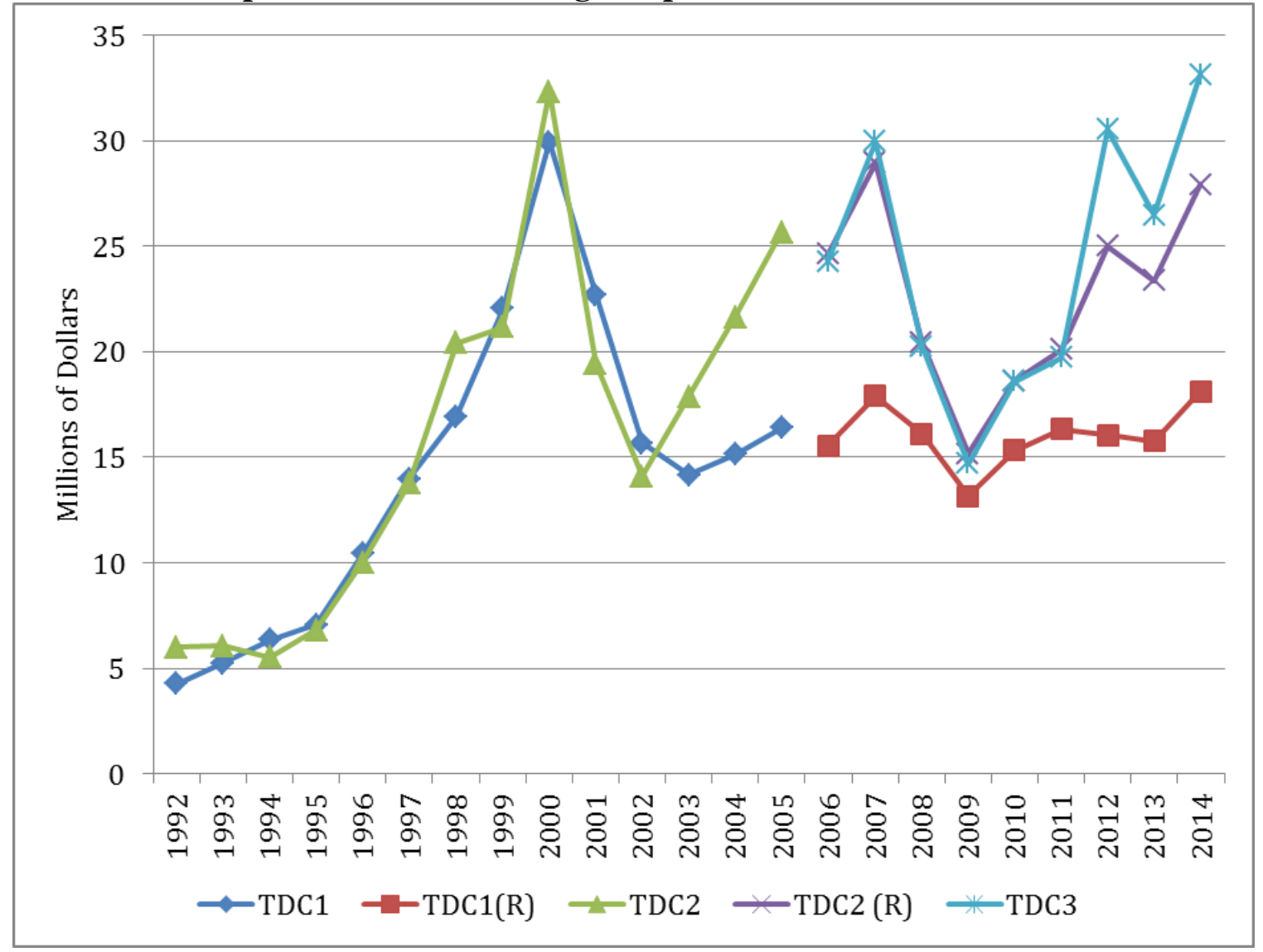

Source: Authors' calculations, ExecuComp data retrieved May 26, 2016.

Indeed, the use of TDC1/TDC1(R) measures conveys the impression that since 2002 the compensation of the highest-paid executives has been stable compared to the explosion of executive pay in the Internet boom of the last half of the 1990s and has remained low relative to the peak of 2000. The use of TDC2/TDC2(R)/TDC3 tells a very different story about both the level and volatility of executive pay since the early 2000 s.

This discrepancy appears also in Figure 12, where we compare the total compensation measures available since 2006. The TOTAL_SEC and the TOTAL_ALT1 measures, which each use fair-value measures for stock options and stock awards, display relatively stable average total compensation for the 500 highest-paid executives in each year. The TOTAL_ALT2 and TDC3 compensation figures, which include realized gains from stock options and stock awards, however, show volatile incomes that are far greater during stock market peaks. Yet it is the estimates of total executive compensation that use fair-value measures for stock-based pay that get recorded in financial statements filed with the SEC. As we discuss in the next and last section of this paper, it is the estimated fair-value mismeasures of executive pay that Congress and the SEC have made central to the implementation of the Say on Pay and the Pay Ratio Disclosure Rule reforms of the 2010 Dodd-Frank Act, the nation's only "responses" to excessive executive pay. If "in search of excess" should have been the U.S. government executive-pay mission over the past 
quarter century, "in search of estimates" has led U.S. regulators, and the American public, astray.

Figure 12: Comparing fair-value and realized-gains measures of average total compensation of the 500 highest-paid executives, 2006-2104

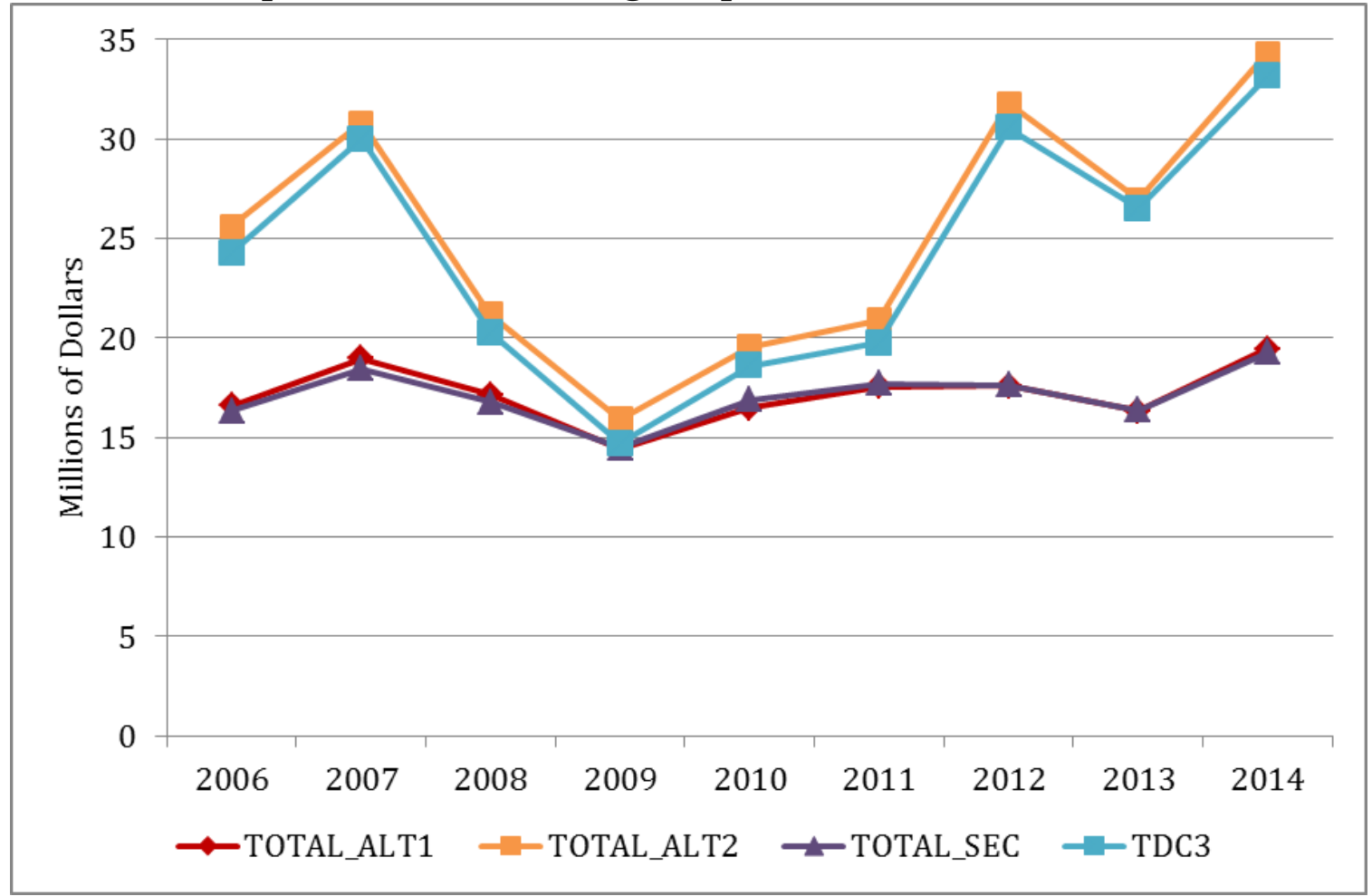

Source: Authors' calculations, ExecuComp data retrieved May 26, 2016.

\section{Measurement matters}

On June 1, 2007, Charles S. Spatt, the SEC's chief economist and director of economic analysis, gave a speech at the Wharton School entitled "Increased Importance of Models: Disclosure, Fair Value, and Accounting." "In recent years," Spatt told participants in a roundtable on model governance and model validation, "there has been considerable focus upon the use of fair value estimates and economic models in accounting, such as for employee stock option expensing." Spatt asserted that reliability of modeling methods for the valuation of employee stock options was "clear from the history of mortgage-backed securities."

He went on:

This analogy is instructive because of the lack of transferability of the mortgage obligation and the importance of the mortgage borrower's risk preferences. Interesting predictions about exercise and forfeiture behavior can be obtained from the mortgage-backed securities perspective and the use of arbitrage principles and the valuation tools of modern financial economics can be adapted to the employee stock option context....Just as these modeling approaches have 
been very successful in the context of mortgage-backed securities, I would expect that analogous tools for employee stock option valuation that take into account the relevant frictions would be similarly fruitful. More broadly, the nature of the development of our capital markets and its heavy reliance upon derivative securities provides evidence of the successful application of these tools. ${ }^{99}$

Some two years after Spatt gave this speech, it was abundantly clear that "the successful application of these tools" for valuing mortgage-backed securities and other derivatives had contributed to the broadest and deepest financial crisis that the United States, and indeed the world, had experienced since the Great Depression. Yet, in responding to the role of excessive executive compensation in the financial crisis of 2008-2009, the DoddFrank Wall Street Reform and Consumer Protection Act of 2010 has enshrined "fairvalue" modeling and accounting in two policy initiatives: Say on Pay and the Pay Ratio Disclosure Rule.

The compensation of executives relies on the "business judgment" of the board of directors and, hence, is not a matter that requires shareholder approval. Without challenging the business-judgment rule, in which senior executives and directors are presumed to make decisions in the best interests of the company, Say on Pay gives shareholders the right to make their views on executive pay known to the board at least once every three years in the form of a non-binding resolution in the company's proxy statement for consideration at the annual general meeting. ${ }^{100}$ Say on Pay assumes that fairmarket valuations of stock-based compensation are accurate representations of the employment income that senior executives receive. The data that we have presented in this paper show that this assumption is incorrect. Clearly, in implementing Say on Pay, the SEC should insist that shareholders consider the actual realized gains of executives of stock-based pay. But the SEC itself, through its collaboration with the FASB, has been a primary promoter of BSM-type fair-value estimates.

As for the Pay Ratio Disclosure Rule, with the SEC's adoption on August 5, 2015, of the "final rule that requires a public company to disclose the ratio of the compensation of its chief executive officer (CEO) to the median compensation of its employees," the SEC is making the fair-value mismeasure of executive pay integral to what will likely become a popular indicator of income inequality. Under the new Pay Ratio Disclosure Rule, the SEC requires companies to report a CEO-to-median-worker pay ratio beginning with the fiscal year that starts on or after January 1, 2017. The SEC's Pay Ratio Disclosure Rule release states: "The new rule, mandated by the Dodd-Frank Wall Street Reform and Consumer Protection Act, provides companies with flexibility in calculating this pay ratio, and helps inform shareholders when voting on 'say on pay.",101

\footnotetext{
${ }^{99}$ Chester S. Spatt. "Increased Importance of Models” Disclosure, Fair Value and Accounting," speech to the Model Governance and Model Valuation Roundtable, Wharton School, June 1, 2007, at https://www.sec.gov/news/speech/2007/spch060107css.htm.

100 "Time to get ready for Say-on-Pay as SEC releases proposed rules," National Law Review, October 26, 2010, at http://www.natlawreview.com/article/time-to-get-ready-say-pay-sec-releases-proposed-rules. 101 "SEC Adopts Rule for Pay Ratio Disclosure."
} 
In fact, as should be obvious from the results on realized-gains and fair-value measures of stock-based pay that we have reported in this paper, the construction of the CEO-tomedian-worker ratio under the Pay Ratio Disclosure Rule misinforms not only shareholders but also anyone else who has an interest in containing and reversing the explosion of executive pay. The SEC views the calculation of CEO pay as unproblematic because it will simply measure annual total compensation "as determined under existing executive compensation rules."

Since 2006, however, these existing SEC rules have companies reporting estimated fairvalue measures of the stock-based compensation of all employees, including senior executives, in order to record that pay as an expense for financial reporting in $10-\mathrm{K}$ and 10-Q filings to the SEC. As we have shown, fair-value measures tend to understate senior executive pay and, from year to year, fail to reflect the volatility of the stock market that drives it. Compared with the amounts of, and changes in, the realized gains of seniorexecutive stock-based pay since the early 2000s, the fair-value estimates, as shown in Figure 11 above, would lead one to believe that the compensation of the highest-paid executives has been both much more moderate and much less volatile than has actually been the case.

The extent of the potential understatement can be illustrated by looking at the CEO-toaverage-worker ratio as reported by the AFL-CIO, the largest federation of unions in the United States, on its Executive Paywatch website. When the AFL-CIO launched Executive Paywatch in April 1997, the data on the compensation of the 500 highest-paid executives that we have presented suggest that on average the ratio may not have been affected significantly by the use of estimated fair value rather than actual realized gains in the calculation of CEO pay, although even then it would have been preferable to record the money that CEOs actually took home rather than an estimate of the amount of money that their vested options might be worth under a dubious set of assumptions. ${ }^{102}$ But, as we have shown in our statistical analysis of the 500 highest-paid executives in each year, since the early 2000s, fair-value estimates consistently understate actual realized gains and give the impression that the level of executive pay in any given year bears little, if any, relation to actual stock-market volatility.

In its 2015 edition of Executive Paywatch, the AFL-CIO reported the CEO-to-averageworker ratio for 2014 as 373:1. The 2014 ratio, as calculated by the AFL-CIO, is based on average total annual compensation of $\$ 13.5$ million for 472 CEOs of companies in the S\&P 500 Index and average worker earnings of $\$ 36,134 .{ }^{103}$ While we have not replicated the AFL-CIO calculation, our analysis of data in the ExecuComp database suggests that the AFL-CIO's ratio for 2014 is far too low. Total compensation of the 500 highest-paid senior executives in the ExecuComp database by TOTAL_ALT2, which includes their realized gains from stock options and stock awards, averaged $\$ 34.3$ million in 2014 , with 81 percent derived from stock-based pay (see Figure 6 above). Using this figure along

102 As we have seen, until 2006 companies did not report the realized gains from stock awards, although before the early 2000s stock awards were relatively unimportant compared with stock options as a form of executive compensation.

103 AFL-CIO, Executive Paywatch, at http://www.aflcio.org/Corporate-Watch/Paywatch-2015. For the the AFLCIO’s 2015 ratio, see http://www.aflcio.org/Corporate-Watch/Paywatch-2016. 
with the AFL-CIO data for average-worker earnings yields a senior-executive-to-averageworker ratio for the 500 highest paid of 949:1 for 2014.

In calculating the ratio, the AFL-CIO uses total compensation data that include the estimated fair-value measures of stock-based pay. For the 500 highest-paid executives in the ExecuComp database, average total compensation using TOTAL_SEC with its fairvalue measures of stock options and stock awards was \$19.3 million in 2014, just 56 percent of the average total compensation of the 500 highest-paid based on realized-gains from stock-based pay (i.e., TOTAL_ALT2). If we use fair-value stock-based pay measures to calculate total compensation for the top 500 executives along with the AFLCIO figure for average-worker earnings, the senior-executive-to-average-worker ratio is 533:1 in 2014 - an exceedingly high ratio but far short of the ratio of 949:1 when the stock-based compensation of the 500 highest-paid executives is accurately measured by realized gains. ${ }^{104}$

If the measure of CEO pay is highly problematic in the SEC's mandated ratio calculation, so too is the median-worker earnings measure. Most companies currently provide little public information about the pay of their workers; even total payroll numbers are usually buried in the "general and administrative" and "research and development" expense items in the 10-K income statement. The SEC's Pay Ratio Disclosure Rule accords substantial flexibility to each company in how it calculates median employee pay, using "any consistently-applied compensation measure from compensation amounts reported in its payroll or tax records." 105 That means that the pay ratios will not be inherently comparable across companies. But, as mandated by the Dodd-Frank Act, as for the CEO figure, the stock-based pay of all other employees that enters in the pay ratio will use estimated fairvalue measures. ${ }^{106}$

104 Economic Policy Institute (EPI) reports that the average total compensation for CEOs at the top 350 companies ranked by sales was $\$ 16.5$ million in 2014 and $\$ 15.5$ million in 2015 , creating a ratio of 303:1 in 2014 and 276:1 in 2015. Lawrence Mishel and Jessica Schieder, "Stock market headwinds meant less generous year for some CEOs," July 12, 2016 at http://www.epi.org/publication/ceo-and-worker-pay-in2015/. The authors contend that the reduction in pay for 2015 reflects a dip in the S\&P 500 stock market index in 2015. See also Lawrence Mishel and Alyssa Davis, "Top CEOs Make 300 Times More than Typical Workers," Economic Policy Institute Issue Brief \#399, June 21, 2015, at http://www.epi.org/publication/topceos-make-300-times-more-than-workers-pay-growth-surpasses-market-gains-and-the-rest-of-the-0-1percent/. Their figures are based on a measure of total pay that includes salary, bonus, restricted stock grants, long-term incentive payouts, and realized gains from stock options. For details on EPI's methodology for calculating its ratio, see Lawrence Mishel and Natalie Sabadish, "Methodology for Measuring CEO

Compensation and the Ratio of CEO-to-Worker Compensation," Economic Policy Institute Working Paper, May 2, 2012, at http://www.epi.org/files/2012/wp293-ceo-to-worker-pay-methodology.pdf. In constructing their long-term time series data, EPI has both an "options realized" (also referred to as "realized direct compensation") and "options granted" definition of total pay. In electing to conform to a measure of total pay developed by the Wall Street Journal, EPI omits from their definition of total pay "Other" compensation which includes perquisites. In addition, EPI apparently does not include realized gains from vested stock awards in their measure of total executive compensation, a major omission given the growing importance of stock awards in executive pay since the early 2000s.

105 “SEC Adopts Rule for Pay Ratio Disclosure." https://www.sec.gov/news/pressrelease/2015-160.html

106 U.S. Congress, Dodd-Frank Wall Street Reform and Consumer Protection Act, January 5, 2010, H.R. 4173529, referring to section 229.402(c)(2)(x) of title 17, Code of Federal Regulations, at https://www.law.cornell.edu/cfr/text/17/229.402. 
With actual CEO pay generally understated through the use of fair-value measures and the determination of the worker-pay methodology at the discretion of each company, the new Pay Ratio Disclosure Rule will obscure more than it illuminates. The SEC should create a transparent standard for reporting average and median employee earnings that is uniform across all companies. At the same time, the SEC needs to change the way in which it requires companies to calculate $\mathrm{CEO}$ compensation in constructing its pay ratio. The SEC should rid financial statements of fair-value accounting estimates of stock-based pay and, in line with the IRS, use actual realized gains.

The SEC relies on the FASB for GAAP, and the FASB has been busy refining the recording of measures related to stock-based compensation in company financial statements. A recent accounting directive of the FASB, ASU 2016-09, ${ }^{107}$ seeks to simplify recording of the "excess tax benefit from share-based compensation" by recognizing it as an income-tax deduction from "provision for income taxes" in the corporate $10-\mathrm{K}$ income statement. In fact, the change in recording will dissolve the link that currently exists between a company's tax returns and its financial statements in accounting for the realized gains from stock-based pay while displaying the inconsistency between the realized-gains and fair-value measures of stock-based pay in the company's income statement.

Recall that the justification of the IRS for treating realized gains on stock-based pay as a corporate expense is that the corporation could have sold the shares on the stock market that employees acquired from options and awards. By this reasoning, it is logical for the company to record the financial benefits that it receives from employee stock-based compensation as additional paid-in capital (APIC) in its shareholders' equity statement. When employees exercise stock options, the cash payments for the shares at the exercise price are booked as APIC. If, for the company, the realized gains of stock-based pay (both options and awards) are greater than the fair-value estimate, the excess stock-based tax benefit also increases APIC. ${ }^{108}$ In the company's cash-flow statement, the excess is recorded as a cash inflow under "financing activities," reflecting the increase in APIC, while an offsetting reduction in cash flow is recorded under "adjustments to reconcile net income to net cash from operations" because in the income statement the excess stockbased tax benefit, based on realized gains, is included in "provision for income taxes" even though stock-based compensation is expensed using fair-value accounting.

Under FASB's ASU 2016-09 simplification, the excess tax benefit for stock-based compensation will no longer contribute to APIC, and hence there will be no need for a "financing activity" entry in the cash flow statement. Nor will there be a need for an offsetting "adjustment" entry in the cash flow statement because now that adjustment will be recognized directly in the income statement. Of course, the need to make this adjustment arises because of the sanctioning by the FASB and the SEC of fair-value

\footnotetext{
107 FASB, “Compensation - Stock Compensation (Topic 718): Improvements to Employee Share-Based Payment Accounting, "Accounting Standards Update No. 2016-09, March 2016, at

www.fasb.org/jsp/FASB/Document_C/DocumentPage?cid=1176168028584\&acceptedDisclaimer=true. See also Sandie Kim, Rob Morris, and John Franco, "Easy Does It: FASB Simplifies the Accounting for Share-Based Payments," Deloitte., April 21, 2016, at http://www.iasplus.com/en/publications/us/heads-up/2016/issue13.

108 If there is a "deficiency" of realized gains to fair value, the signs of all of the accounting entries are reversed.
} 
estimates for stock-based compensation in financial statements that differ from actual realized gains used in the corporate income-tax return that determines the company's tax bill. Hence, under ASU 2016-09, the recognition of the need for an adjustment to the reported tax bill in the company's income statement is in effect a statement of the extent to which the fair-value estimate of employee stock-based compensation is in error, given actual realized gains.

We would suggest that FASB's next step at "simplification" should be to jettison BSMstyle fair-value accounting altogether, and thus get rid of a deeply flawed and highly misleading mode of measuring employee stock-based compensation. As we have emphasized throughout this paper, it is the prospect of realized gains from stock-based pay, and not an estimated "fair value" measure, that incentivizes executives to take actions designed to boost stock prices. It is the exercising of stock options and the vesting of stock awards that provide the rewards that executives realize through an increase in a company's stock price and which generate the lion's share of their take-home, taxable pay. ${ }^{109}$ There is absolutely no justifiable reason why a company should use estimated stock-based compensation expenses rather than actual stock-based compensation expenses in its income statement. As applied to stock options, the FASB-SEC "fair-value project" was illadvised while the use of estimated fair-value measures of executive stock-based compensation in Say on Pay and the Pay Ratio Disclosure Rule is highly misleading.

Congress has already recognized that, because of the different measures of stock-based pay, publicly listed companies keep two sets of books, one for the SEC and one for the IRS. In 2007 Sen. Carl Levin (D-MI) held a hearing on "Executive Stock Options: Should the Internal Revenue Service and Stockholders Be Given Different Information?," in which it was noted that since the early 2000s there had been a "book-tax gap" between the corporate financial statements filed with the SEC (known as "the book") and corporate income-tax returns filed with the IRS. ${ }^{110}$ The result was that corporations were receiving income-tax credits from stock-based compensation expensed in their tax returns, but were recording no stock-based compensation expense prior to FAS $123 \mathrm{R}$ or a low expense subsequent to its implementation. The practical effect is that reported earnings in corporate $10-\mathrm{K}$ and $10-\mathrm{Q}$ statements are higher than those in the same companies' tax returns.

Levin's "book-tax gap" is reflected in the difference that we illustrated, beginning in 2003, between the estimated fair-value measure and actual realized-gain measure of the stockbased pay of the 500 highest-paid executives. Note, however, that the title of Levin's hearing, "Executive Stock Options," is misleading because the source of the book-tax gap is the fair-value/realized-gains gap in valuing all employee stock-based pay, including awards as well as options, and not just executive stock options. To get rid of the book-tax gap, the SEC should require the expensing of realized gains in corporate financial statements, and do away with the faulty fair-value measures of stock-based compensation.

109 Lazonick, "Taking Stock"; Lazonick, "Stock Buybacks.”

110 United States Senate, Committee on Homeland Security and Governmental Affairs, "Executive Stock Options: Should the Internal Revenue Service and Stockholders Be Given Different Information?" Hearing before the Permanent Subcommittee of Investigations of the Committee on Homeland Security and Governmental Affairs, United States Senate, 110 th Congress, First Session, June 5, 2007. 
Sen. Levin was concerned with the tax implications of the book-tax gap. In contrast, in analyzing the determinants of executive pay, our main concern is not with tax policy but with corporate governance. For at issue is not just how much executives get paid and taxed, but, more importantly, how they get paid, precisely because how they get paid is a determinant of their corporate resource-allocation decisions. This same point was made in 1990 in a well-known paper by Michael C. Jensen and Kevin J. Murphy, "CEO Incentives - It is Not How Much You Pay, But How," published in Harvard Business Review. ${ }^{111}$ But, as apostles of the ideology of "maximizing shareholder value," Jensen and Murphy argued that stock-based pay should be made a significant component of the compensation of senior executives, believing that this would align their incentives with the economic interests of shareholders. Indeed, more than any other academic, using an approach known as "agency theory," Jensen preached the benefits to the economy of "disgorging" the "free" cash flow from corporations in the name of "maximizing shareholder value" (MSV). ${ }^{112}$

What Jensen and his agency-theory followers see as the solution to the efficient allocation of resources in the economy, we see as the problem. It is companies, not stock markets or shareholders, that generate the high-quality, low-cost products that result in economic growth. It is the sharing of the gains of that growth within the enterprise that incentivizes managers and workers to contribute to increased productivity. What is more, when those gains are shared equitably, the growth of new firms or continuing operation of existing firms promotes a rising standard of living of the labor force. A well-developed stock market, like a well-developed labor and product market, is the result, not the cause, of the growth of innovative enterprises. ${ }^{113}$ The foundations of economic prosperity reside in business organizations that engage in a "retain-and-reinvest" allocation regime; these companies retain people and money for the sake of investing in the development of productive capabilities that would not otherwise exist. ${ }^{114}$

The notion of "disgorging" the "free" cash flow is a highly ideological proposition. Under the "downsize-and-distribute" allocation regime that agency theorists advocate, it is the very people whose skills and efforts have generated the value who, through "disgorging" cash flow through massive stock repurchases, are "free" to be thrown out of work. Indeed, the evocative term "disgorge" implies that somehow financial resources have illegitimately ended up under the control of a business enterprise when they should be circulating freely in the economy. When agency theorists argue that the company should "return" capital to shareholders through dividends and buybacks, they fail to note that in the vast majority of cases, these shareholders never invested in the company in the first place. Rather, they simply purchased corporate shares outstanding on the stock market,

\footnotetext{
111 Michael C. Jensen and Kevin J. Murphy, "Performance Pay and Top Management Incentives" Journal of Political Economy, 98, 2, 1990: 225-264.

112 See Michael C. Jensen, "Agency Costs of Free Cash Flow, Corporate Finance, and Takeovers," American Economic Review, 76, 2, 1986: 323-329.

113 William Lazonick, "The Chandlerian Corporation and the Theory of Innovative Enterprise," Industrial and Corporate Change, 19, 2, 2010: 317-349; Lazonick, "Innovative Enterprise and Shareholder Value"; William Lazonick, "The Theory of Innovative Enterprise: Foundation of Economic Analysis," AIR Working Paper, August 2015, at www.theAIRnet.org; Lazonick. "Innovative Enterprise or Sweatshop Economics?".

114 Lazonick and O’Sullivan, "Maximizing Shareholder Value."
} 
with no cash directly invested in the productive capabilities of their selected company. How can a company return capital to shareholders if those shareholders never gave the company capital in the first place?

In a modern economy based on large publicly listed corporations that have in the past experienced rapid growth, shareholders function as value extractors, not value creators. As a general proposition, the enterprise came to control productive resources because at some point in its history it was innovative; that is, it was capable of generating a higherquality, lower-cost product than was otherwise available on the market. If, as is often the case, the business enterprise has stopped being innovative, then one needs a theory of innovative enterprise to understand where it went wrong and what to do about it in terms of incentivizing value creation and reallocating corporate resources.

Since the 1980s, as part and parcel of the explosion of executive pay, MSV ideology has governed U.S. business corporations. But, to repeat, MSV is an ideology of value extraction, not value creation. The proponents of MSV argue that by making stock-based pay a major proportion of executive compensation, the incentives of corporate managers in the allocation of resources can be aligned with those of public shareholders. Only if the corporation's "free cash flow" is disgorged to shareholders, the MSV proponents contend, will the economy's resources be allocated to their most efficient uses. The money from the corporate coffers can be distributed to shareholders in the forms of cash dividends and stock repurchases.

The MSV argument is that, of all participants in the business corporation, shareholders are the only economic actors who make productive contributions without a guaranteed return. All other participants such as creditors, workers, suppliers, and distributors allegedly receive a market-determined price for the goods or services that they render to the corporation, and hence take no risk of whether the company makes or loses money. On this assumption, only shareholders have an economically justifiable claim to the "residual" of revenues over costs after the company has paid all other stakeholders their guaranteed contractual claims for their productive contributions to the firm.

By the MSV argument, shareholders are the only stakeholders who need to be incentivized to bear the risk of investing in productive resources that may result in superior economic performance. As the only "residual claimants," the MSV story goes, shareholders are the only stakeholders who have an interest in monitoring managers to ensure that they allocate resources efficiently. Furthermore, by buying and selling corporate shares on the stock market, public shareholders, it is argued, can directly reallocate resources to uses that are more efficient than investments within the corporation.

There are two fundamental flaws with this argument. The first flaw is the contention that, via the stock market, public shareholders allocate resources to more efficient uses. As a general rule, they do not. Passive shareholders merely use the stock market to generate returns on their household savings to augment their incomes while at work or in retirement. Most representative today of active shareholders are hedge-fund activists who seek to extract value from companies so that they can build their hedge-fund "war chests," 
and thus increase their power to extract even more value from companies. ${ }^{115}$ And MSV is the ideology that legitimizes this looting of the industrial corporation.

The second flaw with MSV lies in the erroneous assumption that shareholders are the only corporate participants who bear risk. Taxpayers through government agencies and workers through the firms that employ them make risky investments in productive capabilities on a regular basis. From this perspective, households as taxpayers and workers may have "residual claimant" status: that is, an economic claim on the distribution of profits.

Through government investments and subsidies, taxpayers regularly provide productive resources to companies without a guaranteed return. As an important example, but only one of many, the 2016 budget of the U.S. National Institutes of Health (NIH) is $\$ 32.3$ billion, with a total NIH investment in life-sciences research from 1938 through 2015 of $\$ 958$ billion in 2015 dollars. ${ }^{116}$ Businesses that make use of life-sciences research benefit from the public knowledge that the NIH generates. As risk bearers, taxpayers who fund such investments in the knowledge base, or physical infrastructure such as roads, have a claim on corporate profits if and when they are generated. Through the tax system, governments, representing taxpayers in general, seek to extract this return from corporations and individuals that reap the rewards of government spending. However, tax revenues on the prospective gains from innovation depend on the success of innovative enterprise while, through the political process, tax rates on those gains are subject to change. Hence, for both economic and political reasons, the returns to taxpayers whose money has been invested for the benefit of business enterprises are by no means guaranteed.

Workers regularly make productive contributions to the companies for which they work through the exercise of skill and effort beyond those levels required to lay claim to their current pay, but without guaranteed returns. ${ }^{117}$ Any employer who is seeking to generate a higher-quality, lower-cost product knows the profound productivity difference between employees who just punch the clock to get their daily pay and those who engage in learning to make productive contributions through which they can build their careers and thereby reap future returns in work and in retirement. Yet these careers and the returns that they can generate are not guaranteed.

As risk bearers, therefore, taxpayers whose money supports business enterprises and workers whose efforts generate productivity improvements have claims on corporate profits if and when they occur. MSV ignores the risk-reward relation for these two types of economic actors in the operation and performance of business corporations. Instead it erroneously assumes that only shareholders are residual claimants.

The irony of MSV is that the public shareholders whom it holds up as the only risk bearers typically never invest in the value-creating capabilities of the company at all. Rather, they

115 As an example, see Lazonick et al. "What we learn about inequality."

116 National Institutes of Health, "Budget," at http://www.nih.gov/about-nih/what-we-do/budget. See also Lazonick and Tulum, "US Biopharmaceutical Finance."

117 William Lazonick, Competitive Advantage on the Shop Floor, Harvard University Press, 1990; Lazonick, "The Theory of Innovative Enterprise." 
invest in outstanding corporate equities with the expectation that while they are holding the shares dividend income will be forthcoming and with the hope that when they decide to sell the shares the stock-market price will have risen to yield a capital gain. Following the directives of MSV, a prime way in which the executives who control the allocation of corporate resources fuel this hope is by pumping up their company's stock price by allocating corporate resources to stock buybacks. They "disgorge" this cash flow, not for the sake of efficient resource allocation, but rather for the sake of increasing their own stock-based pay.

Since the mid-1980s Corporate America has become addicted to stock buybacks. Until the mid-1980s buybacks were insignificant. But since then, buybacks have become massive and pervasive. ${ }^{118}$ For the decade 2006-2015, U.S. corporations' total net equity issues new share issues less shares taken off the market through buybacks and merger-andacquisition deals - averaged minus $\$ 416$ billion per year. ${ }^{119}$ Over the past three decades, in aggregate, dividends have tended to increase as a proportion of corporate profits. Yet in 1997, for the first time, buybacks surpassed dividends in the U.S. corporate economy and, even with dividends increasing, have far surpassed them in recent stock-market booms.

Over the decade 2006-2015, the 459 companies in the S\&P 500 Index in January 2016 that were publicly listed over the decade expended $\$ 3.9$ trillion on stock buybacks, representing 53.6 percent of net income, plus another 36.7 percent of net income on dividends. ${ }^{120}$ Much of the remaining 9.7 percent of profits was held abroad, sheltered from U.S. taxes. Many of America's largest corporations routinely distribute more than 100 percent of net income to shareholders, generating the extra cash by reducing cash reserves, selling off assets, taking on debt, or laying off employees. ${ }^{121}$

Retained earnings have always been the financial foundation for investment in innovation and sustained employment. These retentions can fund investment in plant and equipment, research and development, and training and retaining employees. If dividends alone are too high, investments in the company's productive capabilities will suffer. The addition of buybacks to dividends over the past three decades reflects a failure of corporate executives to develop strategies for investing in the productive capabilities of the companies over which they exercise strategic control.

Dividends are the traditional and legitimate way for a publicly listed corporation to provide income to shareholders. Dividends provide shareholders with an income for (as the name says) holding shares. Moreover, if the firm retains enough of its profits to finance further investment in the company's productive capabilities, there is the possibility (although by no means the certainty) that it will generate competitive products that will help lift its future stock price and the value of the shares held. When, for whatever reason,

\footnotetext{
118 Lazonick, "Stock Buybacks."

119 Board of Governors of the Federal Reserve System, Federal Reserve Statistical Release Z.1, "Financial Accounts of the United States: Flow of Funds, Balance Sheets, and Integrated Macroeconomic Accounts," Table F-223: Corporate Equities, December 10, 2015, at http://www.federalreserve.gov/releases/z1/current/.

120 Calculations from the stock-buyback database of the Academic-Industry Research Network, constructed and maintained by Mustafa Erdem Sakinç and Emre Gomeç.

${ }^{121}$ Lazonick, "Labor in the Twenty-First Century”: Lazonick, “How Stock Buybacks Make Americans Vulnerable."
} 
shareholders who have benefited from a stream of income on their holdings decide to sell some or all of their shares, they stand to make a capital gain.

In contrast, by creating demand for the company's stock that provides an immediate boost to its stock price, buybacks reward those shareholders who sell their shares. The most prominent sharesellers are those stock-market traders, including corporate executives, investment bankers, and hedge-fund managers, who are able to time their stock sales to take advantage of buyback activity done as open-market repurchases. Buybacks also automatically increase EPS by decreasing the number of shares outstanding. Since EPS has become a major metric by which financial interests evaluate the performance of a company, buybacks tend to increase demand for a company's stock, thus creating opportunities for stock-market speculators to sell their shares at a gain even in the absence of increased corporate revenues or profits.

Corporate executives give a number of reasons for doing buybacks. ${ }^{122}$ All are deeply flawed: ${ }^{123}$

- Executives claim that they are making an investment in the company because its stock is undervalued. But the evidence is overwhelming that most buybacks occur when stock prices are high, not when they are low.

- Executives claim that their companies do buybacks to offset dilution of EPS that results when employees exercise stock options that they have received as part of their compensation. But if stock-based pay is supposed to induce employees to work harder and smarter, then those who receive it should have to wait until their efforts pay off in higher corporate earnings and stock prices rather than expecting to gain right away from buybacks that increase EPS by simply reducing the number of shares outstanding.

- Executives may claim that buybacks are done when the company is mature and new investment opportunities have vanished. But any CEO who makes this argument is not doing his or her job of devising a strategy to invest in the company's future.

The only logical explanation for the prevalence of buybacks is that stock-based pay gives executives ample incentives to do them. ${ }^{124}$ Yet, while, in the name of MSV and incentivized by stock-based pay, the looting of the industrial corporation has been taking place over the past three decades, the government regulator, the accounting standardsetting board, labor unions, and the news media have been advocating and citing incorrect measures of the compensation that incentivizes and rewards senior corporate executives.

The correct information is available. Once one focuses on actual rather than estimated executive pay, one cannot miss the importance of its stock-based components in determining both the levels of and changes to the compensation of those senior executives who control resource allocation in the nation's publicly listed corporations. That knowledge focuses our attention on the role of stock-based pay in not only putting income into the hands of the richest U.S. households but also, and more importantly, incentivizing

122 Lazonick, "Profits Without Prosperity."

123 Ibid.

124 Lazonick, "Taking Stock." 
top executives to allocate corporate resources in ways that result in unstable employment, inequitable earnings, and stifled innovation in the companies that employ them. The problem has origins within each important U.S. company and the impact spreads to the U.S. economy as a whole. The use of the fact of actual realized gains in the public discourse on executive pay would position the people to demand that Congress and the SEC cease sanctioning and promulgating the fiction of estimated fair value and confront the profound problems caused by incentivizing and rewarding executive greed. 